\title{
Sediment Provenance Study of the Lower Hamilton Group: An Analysis of the Organic-Rich Facies and its Depositional History
}

Luke Patrick Fritz

West Virginia University, Ipf0007@mix.wvu.edu

Follow this and additional works at: https://researchrepository.wvu.edu/etd

Part of the Geochemistry Commons, Geology Commons, and the Sedimentology Commons

\section{Recommended Citation}

Fritz, Luke Patrick, "Sediment Provenance Study of the Lower Hamilton Group: An Analysis of the OrganicRich Facies and its Depositional History" (2019). Graduate Theses, Dissertations, and Problem Reports. 3899.

https://researchrepository.wvu.edu/etd/3899

This Thesis is protected by copyright and/or related rights. It has been brought to you by the The Research Repository @ WVU with permission from the rights-holder(s). You are free to use this Thesis in any way that is permitted by the copyright and related rights legislation that applies to your use. For other uses you must obtain permission from the rights-holder(s) directly, unless additional rights are indicated by a Creative Commons license in the record and/ or on the work itself. This Thesis has been accepted for inclusion in WVU Graduate Theses, Dissertations, and Problem Reports collection by an authorized administrator of The Research Repository @ WVU. For more information, please contact researchrepository@mail.wvu.edu. 


\title{
Sediment Provenance Study of the Lower Hamilton Group: An Analysis of the Organic-Rich Facies and its Depositional History
}

\author{
Luke P. Fritz
}

\author{
Thesis submitted \\ to the Eberly College of Arts and Sciences \\ at West Virginia University
}

in partial fulfillment of the requirements for the degree of

Master of Science in

Geology

\author{
Amy Weislogel, Ph.D., Chair \\ Kathleen Benison, Ph.D. \\ Timothy Carr, Ph.D. \\ Department of Geology and Geography \\ Morgantown, West Virginia \\ 2019
}

Keywords: Marcellus Shale, Sediment Provenance, Hamilton Group, Raman, Rare Earth

Copyright 2019 Luke P. Fritz 


\section{ABSTRACT \\ Sediment Provenance Study of the Lower Hamilton Group: An Analysis of the Organic-rich Facies and Their Depositional Histories}

\section{Luke P. Fritz}

Currently, insufficient geological models exist to explain the variability and distribution of TOC in the Marcellus Shale, within the Hamilton Group. TOC is one of the several limiting factors for natural gas production within the Marcellus Shale basin. One possible explanation for the low TOC regions is that detrital dilution was variable across the basin, with different sediment sources contributing detritus to low TOC areas, compared to surrounding regions with higher TOC. This hypothesis is tested by analyzing the source composition of inorganic detritus, using elemental and mineralogical proxies, with two cores in the Hamilton Group. The Armstrong \#1 core is located in Taylor County, West Virginia and the Coldstream Affiliates $1 \mathrm{MH}$ (CSA) core is located in Clearfield County, Pennsylvania. Both these wells are located outside of the higher productivity regions with a nearby horizontal Armstrong well totaling 0.45 $\mathrm{BCF} / 1000 \mathrm{ft}$ lateral and a nearby horizontal CSA well totaling $0.41 \mathrm{BCF} / 1000 \mathrm{ft}$ lateral. Variation in production may also result from over maturation of the kerogen-hosted pores. To evaluate the influence of thermal history, the thermal maturity of the Marcellus Shale in the lower productivity Armstrong \#1 and CSA wells and the higher productivity MSEEL well was assessed using Raman spectroscopy.

Major element, trace element, and REE geochemistry indicate the sediment source area was composed of intermediate and felsic granitic and recycled sedimentary lithologies. Samarium-neodymium isotopic analysis reveals a range of $\boldsymbol{\tau}_{\mathrm{DM}}$ ages and $\varepsilon_{\mathrm{Nd}}$ values. The Armstrong \#1 well $\boldsymbol{\tau}_{\mathrm{DM}} / \varepsilon_{\mathrm{Nd}}$ ranged from 1.64 to $1.91 \mathrm{Ga} /-11.93$ to -9.56 and the CSA from 1.62 to $1.88 \mathrm{Ga} /-12.07$ to -11.12 . The $\varepsilon_{\mathrm{Nd}}$ values became more negative upsection, however the $\boldsymbol{\tau}_{\mathrm{DM}}$ did not display a consistent trend relative to depth. Provenance analysis indicates the most likely source of clastic sediment was the Acadian Fold-Thrust Belt to the east with minor inputs from Superior Craton and southern Canadian Grenville Province. Ultimately, results conclude that elevated TOC was associated with only older $\boldsymbol{\tau}_{\mathrm{DM}}$ ages and recycled sedimentary signatures. 


\section{TABLE OF CONTENTS}

ACKNOWLEDGEMENTS .................................................................................................................. v

LIST OF FIGURES …............................................................................................... vii

LIST OF TABLES AND EQUATIONS ............................................................................ xi

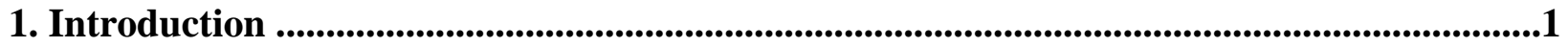

1.1 Controls on Marcellus Shale TOC...............................................................................1

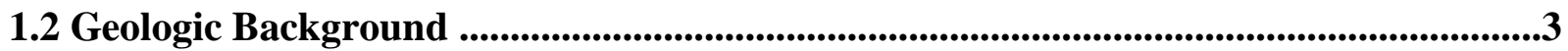

1.3 Previous Studies Related to Provenance of the Hamilton Group........................................5

2. Methodology ............................................................................................................................................

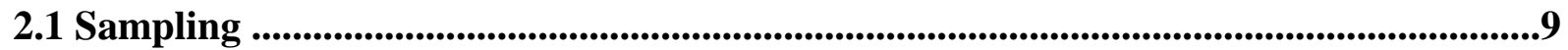

2.1.1 Coldstream Affiliates 1MH ...............................................................................................9

2.1.2 Armstrong \#1 ..............................................................................................................................9

2.1.3 MSEEL MIP-3H............................................................................................................9

2.2 Analytical Methods........................................................................................................................10

2.2.1 Samarium-Neodymium (Sm-Nd) Isotopic Analysis......................................................10

2.2.2 Inductively Coupled Plasma Mass Spectroscopy (ICP-MS).....................................12

2.2.3 Raman Spectroscopy.............................................................................................................13

2.2.4 Thin Section Petrography..................................................................................................14

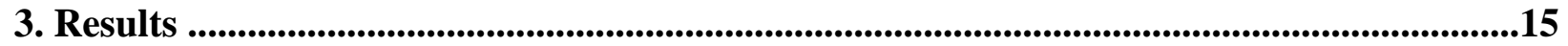

3.1 Geochemical Results.................................................................................................15

3.1.1 Samarium-Neodymium (Sm-Nd) Isotopic Analysis.......................................................15

3.1.2 Trace element and REE Geochemistry..........................................................................16

3.1.3 Thermal Maturity from Laser Raman Spectroscopic Analysis...............................21

3.2 Thin Section Petrography...........................................................................................................22

4. Discussion.......................................................................................................................................25

4.1 Geochemistry of Potential Sediment Sources.........................................................................25

4.2 Hamilton Group Sediment Source Area Characterization: Lithology, and Geochemistry ……......................................................................................................................26 
4.2.1 Major, Trace, and REE Concentrations........................................................................26

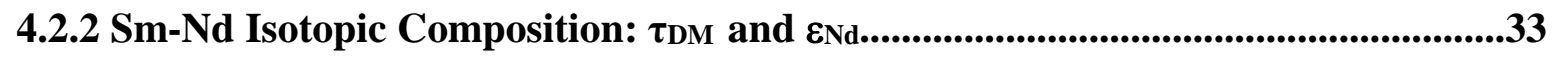

4.2.3 XRD Mineralogy

4.3 Comparison to Various Source Compositions...................................................................34

4.3.1 Major, Trace \& REE Geochemistry Abundances.............................................34

4.3.2 Signatures from Sm-Nd Radiogenic Isotopes........................................................43

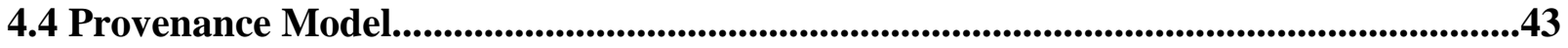

4.4.1 Sediment Source Area.....................................................................................................43

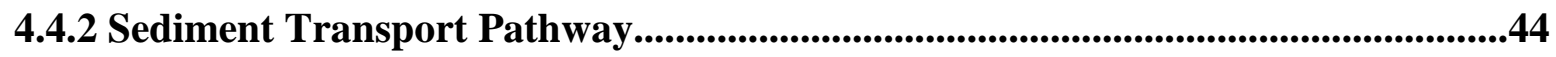

4.4.3 Temporal Provenance Evolution...........................................................................46

4.5 Thermal Maturity from Laser Raman Spectroscopic Analysis...................................49

4.6 Relationship between Provenance and Controls on Organic-Matter Preservation......50

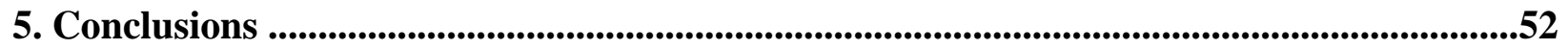

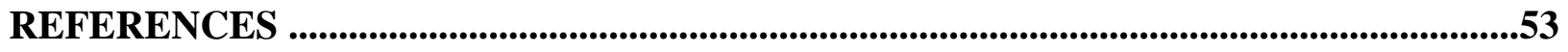

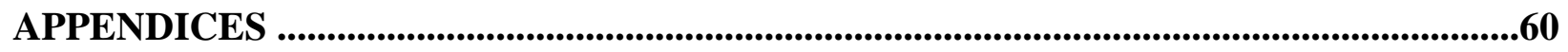

Appendix I. ICP-MS Elemental Data................................................................................66

Appendix II. Thin section petrography results................................................................63

Appendix III. Armstrong \#1 Well XRD Data............................................................................68

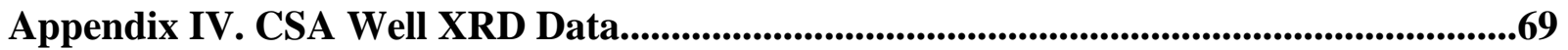

Appendix V. Sm-Nd Isotopic Data..........................................................................70

Appendix VI. Laser Raman Data at Every Depth..................................................................71

Appendix VII. Six Peak fit of a Laser Raman Spectrum....................................................76

Appendix VIII. REE Concentrations Compared to $\tau_{\mathrm{DM}}$ and $\varepsilon$ Nd..........................................77 


\section{Acknowledgements}

I am very grateful for all of the people and organizations that have helped me along my way, not only through graduate school but also throughout my whole educational career. I must make the first acknowledgement to my parents. Without their support from grade school all the way to graduate school, I would not be where I am today. I next would like to thank my beautiful and supportive fiancée Jess. She listened through many ramblings of rocks and attempted to understand them despite her psychology background. I would also like to thank all of my graduate colleagues that gave me insight and listened to my various tangents about rocks. My

office mates Shelby Isom, Jackson Jakeway, and Sofia Andeskie (an honorary office mate) were most integral in keeping me levelheaded and being great friends.

I am very appreciative for all the support that my advisor, Dr. Amy Weislogel, has given me. Coming into graduate school at West Virginia University, I did not know what research project I wanted to pursue. Dr. Weislogel was able to help me develop a thesis project that not only fit my interests but also set me up for employment after. I am very grateful for this. Moreover, I would like to thank my committee members Dr. Timothy Carr and Dr. Kathleen Benison. Dr. Carr's knowledge of the Appalachian Basin and unconventional reservoirs was integral for my research. Dr. Benison’s knowledge of sedimentology and Raman spectroscopy was very important for my interpretations of my data. Also, Dr. Ken Brown helped tremendously with providing software to plot rare earth element trends and with ideas about elements and their relationship to provenance. Furthermore, I would like to thank the rest of the faculty WVU Department of Geology and Geography for broadening my geologic knowledge and offering challenging and thought provoking classwork. 
Without funding, this research would not have been possible. I would like to thank AAPG (American Association of Petroleum Geologists) Foundation Grants-In-Aid for granting me the Frederick A. Sutton Memorial Grant. I would like to thank the WVU Department of Geology and Geography for granting me the John M. Dennison Scholars Award. Finally, I would like to thank SEPM (Society for Sedimentary Geology) for granting me one of the foundation's Student Research Grants.

Many resources helped me complete this research as well. All of the data from the MIP3H well (part of the MSEEL well) is provided by Brittany Hupp in her thesis completed in 2017. Some of the data on the Armstrong and Coldstream well cores was collected from previous studies. Handheld XRF data is of these cores provided by NETL, specifically Dustin Crandall, Thomas Paronish, Sarah Brown, and Paige Mackey. PDC Mountaineer donated XRD, vitrinite reflectance values, and logs of the Armstrong well. XRD, vitrinite reflectance values, and logs of the Coldstream well were donated by ECA (Energy Corporation of America) now part of Greylock Energy. Thank you to Phil Dinterman, Keithan Martin, and Dustin Crandall (again) for helping me gain access the Armstrong \#1 and Coldstream cores. Finally, I am very grateful to the staff at RJ Lee Group, namely Dr. Jason Lupoi and Steve Schlaegle. Before I started work at West Virginia University, I interned at RJ Lee Group working with black shales using their Raman Spectrometer. I believe this experience allowed me to broaden my research goals and gave me great exposure to the many analytical methods available for scientific research. 


\section{LIST OF FIGURES}

Figure 1. Sediment provenance possibilities of the Marcellus Shale.

Figure 2. Middle Devonian strata of the Appalachian basin.

Figure 3. Paleo-wind directions during the deposition of the Marcellus Shale.

Figure 4. Sampling density of the Armstrong \#1, MSEEL, and CSA wells.

Figure 5. Sediment source discrimination diagram.

Figure 6. Aluminum, calcium, sodium, and potassium elemental concentrations determined source compositions.

Figure 7. Aluminum, calcium, sodium, potassium, iron, and magnesium elemental concentrations determined source compositions.

Figure 8. Sediment source diagram using concentrations of thorium, zirconium, and scandium.

Figure 9. $\quad \varepsilon N d$ versus $\mathrm{Th} / \mathrm{Sc}$ ratio to indicate the provenance source type.

Figure 10. REEs in the Armstrong \#1 and CSA wells.

Figure 11. Armstrong \#1, CSA, and MSEEL well averaged depth laser Raman spectra.

Figure 12. Thin sections from the Lower Mahantango and Union Springs Member.

Figure 13. Elemental ratios of $\mathrm{Si} / \mathrm{Al}$ and $\mathrm{Ti} / \mathrm{Al}$ from the handheld XRF on the Armstrong \#1, MSEEL, and CSA cores

Figure 14. Cross plot of TOC vs. Si/Al for the CSA, Armstrong \#1, and MSEEL wells.

Figure 15. Cross plot of $\mathrm{Zr} / \mathrm{Al}$ vs. Si/Al for the CSA and Armstrong \#1 wells.

Figure 16. XRD mineralogy of the Armstrong \#1, MSEEL, and CSA wells.

Figure 17. Major and trace element concentrations of the Armstrong \#1 and CSA wells normalized to average trace element concentrations of the grantitic Acadian FoldThrust Belt Inliers.

Figure 18. Trace element concentrations of the Armstrong \#1 and CSA wells normalized to average trace element concentrations of the Taconic Sedimentary Sequence (part of the Acadian Fold-Thrust Belt).

Figure 19. Major and trace element concentrations of the Armstrong \#1 and CSA wells normalized to average trace element concentrations of the Acadian Arc.

Figure 20. Major and trace element concentrations of the Armstrong \#1 and CSA wells normalized to average trace element concentrations of the Superior Craton. 
Figure 21. Major and trace element concentrations of the Armstrong \#1 and CSA wells normalized to average trace element concentrations of Barillia.

Figure 22. REE concentrations normalized to chondrite. Comparison is made between the Armstrong \#1 and Coldstream wells and the New Jersey Highlands compositions.

Figure 23. REE concentrations normalized to chondrite. Comparison is made between the Armstrong \#1 and CSA wells and the Blue Ridge Massif compositions.

Figure 24. REE concentrations normalized to chondrite. Comparison is made between the Armstrong \#1 and Coldstream wells and the Kipawa Syenite Complex compositions.

Figure 25. REE concentrations normalized to chondrite. Comparison is made between the Armstrong \#1 and Coldstream wells and the Kapuskasing Structural Zone compositions.

Figure 26. Map of the Middle Devonian Acadian Basin and generalized sediment sources.

Figure 27. Collective provenance studies of $\boldsymbol{\tau}_{\mathrm{DM}}$ of the Hamilton Group using Sm-Nd isotopes.

Figure 28. Collective provenance studies of $\varepsilon_{\text {Nd }}$ of the Hamilton Group using Nd isotopes.

Figure 29. Wt. \% TOC versus $\boldsymbol{\tau}_{\mathrm{DM}}$.

Figure 30. Wt. \% TOC versus $\varepsilon$ Nd. 


\section{LIST OF TABLES AND EQUATIONS}

Table 1. Descriptions of the different source terranes that could have contributed to the Acadian basin.

Table 2. $\quad \boldsymbol{\tau}_{\mathrm{DM}}$ and $\varepsilon N d$ data for the CSA and Armstrong \#1 wells.

Table 3. G-D band separation from various depths within the MSEEL, Coldstream, and Armstrong \#1 wells.

Table 4. Classifications of the thin sections in both the Armstrong \#1 and CSA wells according to Milliken (2014)

Table 5. Source classification of the Armstrong \#1 and Coldstream wells.

Equation 1. Calculation of Sm-Nd depleted mantle model age $\left(\tau_{\mathrm{DM}}\right)$.

Equation 2. Calculation of $\varepsilon N d$.

Equation 3. Calculation for Discrimination Factor 1 (DF1) from Roser and Korsch (1988).

Equation 4. Calculation for Discrimination Factor 2 (DF2) from Roser and Korsch (1988). 


\section{INTRODUCTION}

\subsection{Controls on Marcellus Shale TOC}

The Marcellus Shale is an organic-rich black shale and unconventional reservoir that extends throughout much of the Appalachian Basin. The complete breadth of the Marcellus Shale is not an economic hydrocarbon resource. There are two regions within the basin that have proven to be economic, one in northeastern Pennsylvania and another in southwestern Pennsylvania/north-central West Virginia (Fig. 1). In these areas, the thick accumulations of organic matter result in Marcellus Shale reservoirs that are highly productive for natural gas, ranging from 1.0 to over 4.0 BCF/1000 lateral feet of gas (Zagorski et al., 2017).

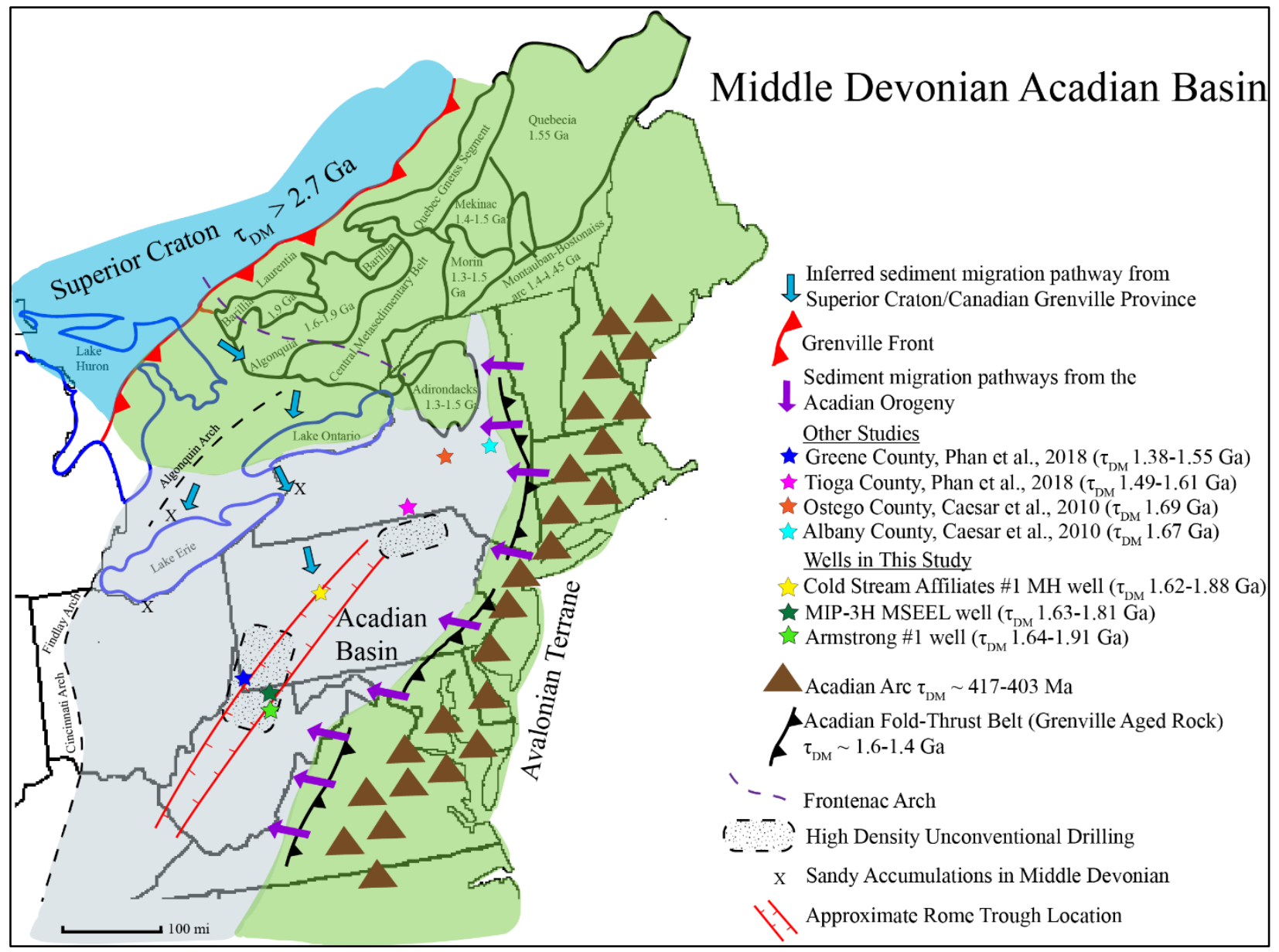

Figure 1. Sediment provenance possibilities of the Marcellus Shale. Data combined from Patchett et al. (1999), Percival et al. (2006), McLelland et al. (2010), Brett et al. (2011), and Zagorski et al. (2017). 
Current models for the deposition of the Marcellus Shale do not sufficiently explain the variability of the organic-rich facies. One explanation for the thinner accumulations of organic facies is that detrital dilution (input of extra-basinal sediment) was greater than the surrounding productive regions. The elements such as $\mathrm{Ti}, \mathrm{Al}, \mathrm{Si}, \mathrm{Fe}, \mathrm{Mg}$, and $\mathrm{K}$, have been used to assess the amount of detrital dilution that occurred during deposition (Werne et al., 2002; Sageman et al., 2003; Ver Straeten, et al., 2011). Other factors such as syn-depositional conditions that control biological productivity, post-depositional degradation related to substrate oxygenation, or thermal over-maturity can limit organic-rich facies preservation. Bathymetric changes can control organic preservation. Paleo-topographic highs are areas of high organic preservation (Harper and Piotrowski, 1978; Lash and Engelder, 2011). Nutrient fluxes in the Middle Devonian enhanced by land plant evolution and efficient nutrient recycling by plankton, may have preferentially enriched certain areas of the basin with organic carbon (Murphy et al., 2000). Thermal maturity values greater than $3.5 \% \mathrm{R}_{0}$ or less than $1.0 \% \mathrm{R}_{0}$ can hinder production of natural gas (Zagorski et al., 2017).

The goal of this study is to evaluate the relationship between sediment provenance and the distribution of organic-rich facies of the Marcellus Shale between north-central West Virginia, southwest Pennsylvania, and central Pennsylvania. Sediment provenance and sediment transport pathways may be responsible for the lack of organic-rich facies in some areas of the Acadian foreland basin as a consequence of detrital dilution. To test this idea, provenance analysis was conducted on Hamilton Group samples from two cored locations with variable organic matter content. One core was taken from the Armstrong \#1 well in Taylor County, West Virginia (Fig. 1), which contains four 5-foot thick organic-rich layers averaging around 6\% TOC. The second core was taken from the Coldstream Affiliates 1MH well in Clearfield County, 
Pennsylvania (Fig. 1), which contains two ten-foot thick beds averaging around 7\% TOC. Both these wells are located outside of the higher productivity region, which is located in southwestern Pennsylvania and northern West Virginia. A horizontal Armstrong well has produced 0.45 BCF/1000ft lateral (WVDEP, 2019) so far and a nearby horizontal CSA well totaling $0.41 \mathrm{BCF} / 1000 \mathrm{ft}$ lateral (PADEP, 2019). Results from provenance analysis of these cores are compared to five other locations in the region to constrain regional detrital sediment input and its relationship to spatial and temporal patterns of organic matter deposition (Caesar et al., 2010; Hupp, 2017; Phan et al., 2018). Furthermore, this study assesses the impact of thermal maturity on the organic-rich facies as part of the comparison (Fig. 1). Previous work indicates the CSA well is situated in a more thermally mature part of the basin than the Armstrong \#1 well due to its proximity to the Appalachian structural front (Zagorski et al., 2017).

\subsection{Geologic Background}

The Middle Devonian (late Eifelian-Givetian ages) Marcellus Shale forms the lower part of the Hamilton Group (Ettensohn, 1985). The Marcellus Shale is made up of three main members: the Oatka Creek, the Cherry Valley/Purcell Limestone, and the Union Springs. The Union Springs is typically more organic-rich than the Oatka Creek (Kohl et al., 2012). The Marcellus Shale lies conformably above the Middle Devonian (Eifelian) Onondaga Limestone and gradationally below the Mahantango Formation which is mainly composed of dark siltstone with minor sandstones and limestone beds (Fig. 2; Harper, 1989, Kohl et al., 2012). During Marcellus Shale deposition, oblique convergence of the peri-Gondwanan Avalon terrane with the North American craton escalated, forming the Acadian Mountains (Ettensohn, 1985). Erosion of convergent highlands created the Catskill Delta of eastern New York/northeast Pennsylvania, which is thought to be the primary source of detrital sediments to the Acadian foreland basin 
(Ettensohn, 1985; Woodrow, 1985). During deposition of the Marcellus Shale, however, the central Acadian Basin has been postulated as overall sediment-starved due to sea-level transgression (basin accommodation outpacing sedimentation rate) in conjunction with an orographic rain shadow caused by the Acadian Mountains to the east (Ettensohn, 1985; Murphy et al., 2000).

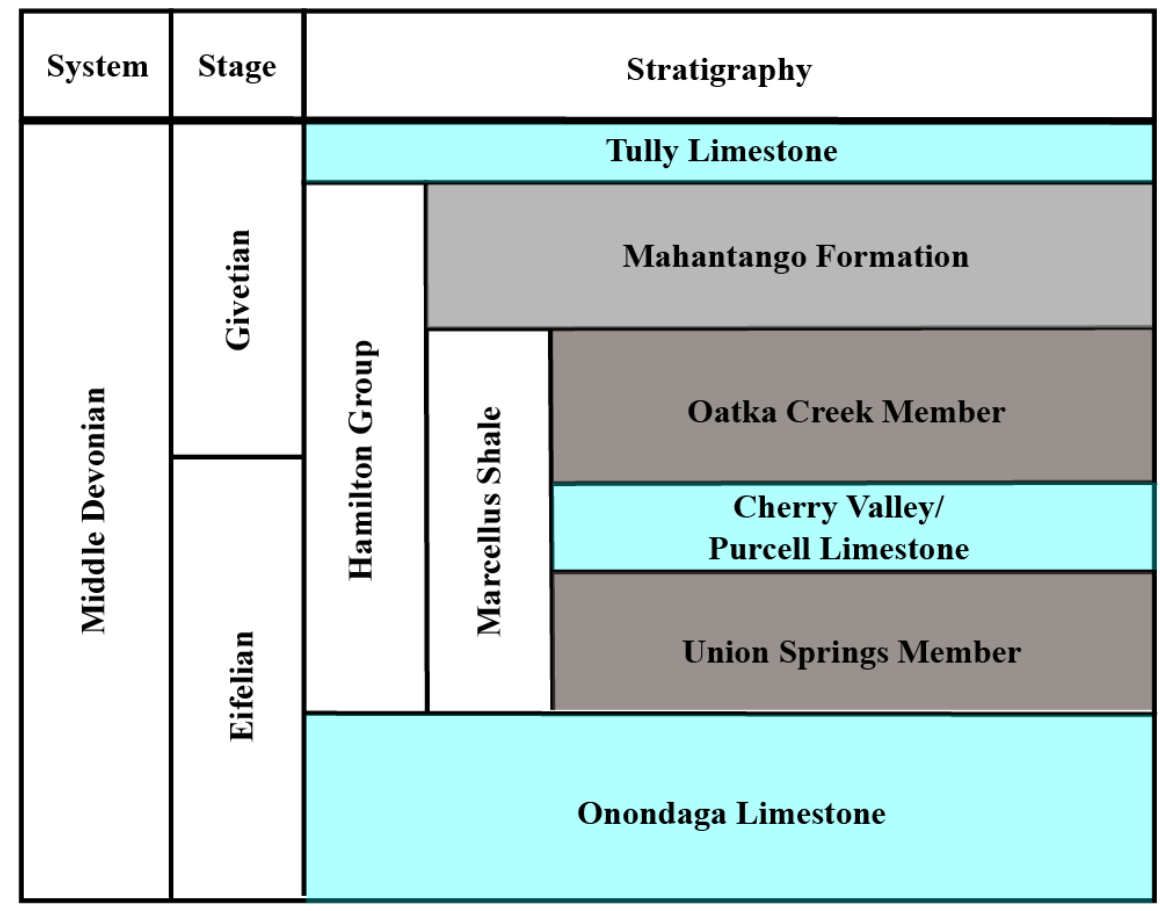

Figure 2. Stratigraphic column depicting Middle Devonian strata of the Appalachian basin. Adapted from Harper (1989).

Deposition of organic-rich facies of the Marcellus Shale was influenced by basin setting, eustacy and paleoclimate. Acadian reactivation of strike-parallel and strike-perpendicular basement faults, related to the middle Cambrian Rome Trough, affected the thickness and the lithology of Marcellus Shale deposits, particularly along the axis of the Acadian retroarc foreland (Fig. 1; Zagorski et al., 2017). Deposition occurred during a period of the highest intracratonic sea level, which resulted in deposition of the organic-rich Union Springs Member (Murphy et al., 
2000); TOC of this unit reaches $17 \%$ in some areas of the basin due to a persistent pycnocline that created anoxia on the bottom of the water column (Zagorski et al., 2017). Furthermore, organic matter production was enhanced by location of the basin roughly $30^{\circ}-35^{\circ}$ south of the equator, where stagnant water columns form as a function of an arid, subtropical climate as is observed in similar modern environments (Fig. 3; Sageman et al., 2003). This aridity is believed to be enhanced by the orographic rainshadow caused by Acadian Mountains highlands to the east (modern coordinates) of the Acadian basin (Ettensohn, 1985).

\subsection{Previous Studies Related to Provenance of the Hamilton Group}

Previous work has explored the provenance of detrital sediment in the Hamilton Group, but existing data is not sufficient to definitively determine the sediment transport pathways. This study's goal was to understand the provenance of the Hamilton Group using Sm-Nd radiogenic isotopic ratios. Sm-Nd radiogenic isotopic ratios provide a method for assessing provenance of Hamilton Group detrital clays, given that Sm-Nd radiogenic isotopic ratios do not fractionate during secondary mineral formation nor are they mobilized by anoxic/organic-rich waters during sedimentary transport and deposition (Depaolo and Wasserburg, 1976; Ohr et al., 1994; Ilina et al., 2013). The potential sources of the Hamilton Group exist to the north and east of the current coordinates in the basin. There are no sources to the west due to the Cincinnati/Findlay Arch. Four potential sources contributed sediment to the Hamilton Group: the Acadian Fold-Thrust Belt that developed along the eastern basin margin ( $\boldsymbol{\tau}_{\mathrm{DM}}=1.6-1.4 \mathrm{Ga} ; \varepsilon_{\mathrm{Nd}}=-5$ to -13$)$, the Acadian Arc that developed in the hinterland of the Acadian Fold-Thrust Belt ( $\boldsymbol{\tau}_{\mathrm{DM}}=450$ Ma; $\varepsilon_{\mathrm{Nd}}=4$ to 2), the Superior Craton to the north ( $\left.\boldsymbol{\tau}_{\mathrm{DM}}>2.7 \mathrm{Ga} ; \varepsilon_{\mathrm{Nd}}>-17\right)$, and the southern Canadian Grenville Province ( $\boldsymbol{\tau}_{\mathrm{DM}}=1.9-1.3 \mathrm{Ga} ; \varepsilon_{\mathrm{Nd}}=-12$ to -17$)$ to the northeast (Table 1$)$. 


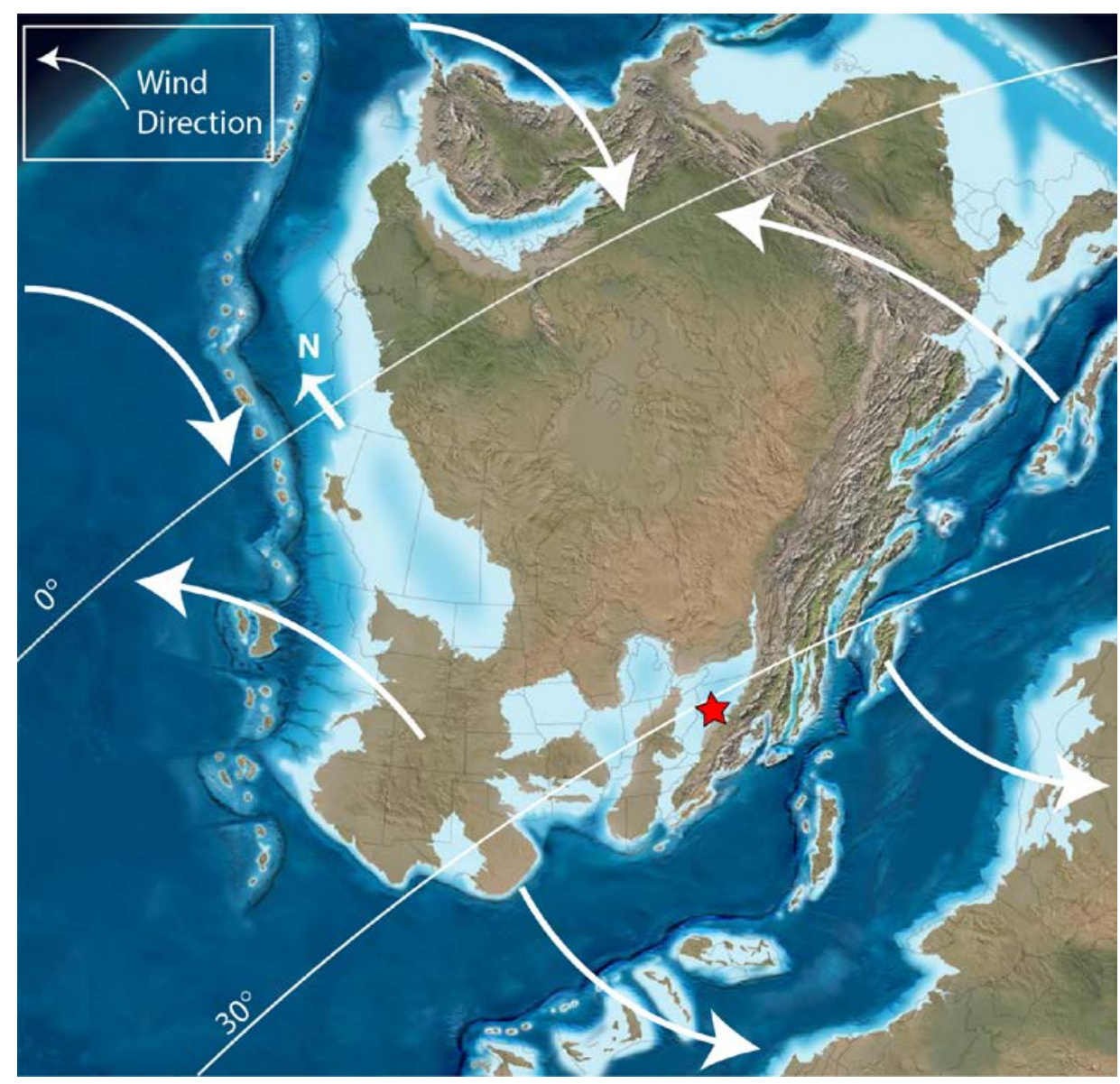

Figure 3. Map showing paleo-wind directions during the deposition of the Marcellus Shale. Red star represents approximate locations of the study wells (Modified from Drewry et al., 1974 and Blakey, 2009).

Table 1. Descriptions of the different source terranes that could have contributed to the Acadian basin. Data from Patchett et al. (1999), Percival et al. (2006), McLelland et al. (2010)

\begin{tabular}{|c|c|c|c|c|}
\hline Terrane Name & Type of Terrane & Composition & ENd & T.M \\
\hline \multirow{2}{*}{$\begin{array}{c}\text { Acadian Fold- } \\
\text { Thrust Belt }\end{array}$} & upper continental crust & felsic igneous & $\begin{array}{c}-5 \text { to } \\
-13\end{array}$ & $\begin{array}{c}1.4 \text { to } 1.6 \\
\mathrm{Ga}\end{array}$ \\
\cline { 2 - 5 } & recycled sedimentary & recycled sedimentary & $\begin{array}{c}-9 \text { to } \\
-20\end{array}$ & $\begin{array}{c}1.6 \text { to } 2.2 \\
\mathrm{Ga}\end{array}$ \\
\hline Superior Craton & upper continental crust & felsic igneous & $\geq-17$ & $>2.7 \mathrm{Ga}$ \\
\hline $\begin{array}{c}\text { Southern Canadian } \\
\text { Grenville Province }\end{array}$ & $\begin{array}{c}\text { upper continental crust } \\
\text { and accreted arcs }\end{array}$ & $\begin{array}{c}\text { felsic igneous and minor } \\
\text { mafic components }\end{array}$ & $\begin{array}{c}-12 \text { to } \\
-17\end{array}$ & $\begin{array}{c}1.3 \text { to } 1.9 \\
\mathrm{Ga}\end{array}$ \\
\hline Acadian Arc & young differentiated arc & $\begin{array}{c}\text { intermediate igneous to } \\
\text { felsic igneous }\end{array}$ & 4 to 2 & $450 \mathrm{Ma}$ \\
\hline
\end{tabular}


Results from several studies infer variable sediment sources for the Marcellus Shale. Recently Phan et al. (2018) found depleted mantle model age ( $\left.\boldsymbol{\tau}_{\mathrm{DM}}\right)$ values of 1.38-1.61 Ga and $\varepsilon_{\mathrm{Nd}}-10$ to -12 from core chips of the Oatka Creek member and the lower Mahantango Formation from both Greene County, Pennsylvania and Tioga County, New York, and interpreted the Acadian Fold-Thrust Belt as the source. Hupp and Weislogel (2018) tested Sm-Nd of core from the Hamilton Group from the MSEEL and WV-6 core recovered near Morgantown, West Virginia. The Sm-Nd isotopic $\boldsymbol{\tau}_{\mathrm{DM}}$ ages ranged from 1.64-1.85 Ga and $\varepsilon N d$ values ranged from 7.06 to -11.65 , becoming increasingly negative upsection and indicating an upper crustal source rock. The study suggested that the older $\boldsymbol{\tau}_{\mathrm{DM}}$ ages, which are found in the Union Springs and Oatka Creek Members of the Marcellus Shale and the Lower Mahantango Formation, resulted from a mixing of minor contribution of Superior Craton derived sediments ( $>2.7 \mathrm{Ga}$ ) with Acadian Fold-Thrust Belt sediment. Caesar et al. (2010) found Sm-Nd isotopic ages of the Hamilton Group ranged between 1.68-1.66 Ga and $\varepsilon N d$ values ranged from -7.63 to -7.70. It argued for direct erosion of the southern Canadian Grenville Province and from the Acadian Fold-Thrust belt as source material for the Marcellus Shale.

Overall, these results depict differences in the origin of clastic material associated with organic-rich facies deposition of the Marcellus Shale. The provenance data from previous studies and this current study show that there is more variability in the $\varepsilon N d$ and $\boldsymbol{\tau}_{\mathrm{DM}}$ signatures within the Union Springs member than within the Oatka Creek member and Mahantango Formation (Caesar et al., 2010; Hupp, 2017; Phan et al., 2018). The uniformity of $\varepsilon N d$ and $\boldsymbol{\tau}_{\mathrm{DM}}$ signatures in the Oatka Creek member and Mahantango Formation may show the dominance of the progradation of the Catskill Delta (or other deltaic sequence), with its source ultimately being the Acadian FoldThrust Belt. Recent correlations suggest that the Union Springs Member may not have a genetic 
depositional link to the prograding Mahantango Formation coarser grained clastics, whereas the upper Oatka Creek member does (Boswell and Pool 2018; see report fig. 4d). If so, then organic-rich facies of these two members may differ in terms of controls on organic deposition and reservoir quality.

\section{METHODOLOGY}

In order to analyze the provenance and assess detrital dilution, core chips from the study wells were acquired from 2 cores. Coldstream Affiliates $1 \mathrm{MH}$ well, located in Clearfield County, Pennsylvania, was targeted for sampling because its understudied basin location and lack of published data relating to Sm-Nd radiogenic isotopes. The Armstrong \#1 well, located in Taylor County, West Virginia, was targeted for sampling to compare and contrast previous results from the MSEEL well located close by in Monongalia County. Core chip samples were used to create thin sections, analyze elemental data, and run laser Raman spectral analysis. Previously collected mineralogical, elemental, and geophysical log analysis augment the data collected in this study. Core Laboratories collected XRD mineralogy and vitrinite reflectance measurements on the CSA and Armstrong \#1 wells before donation to West Virginia University. Wonnell (2015) collected XRD data on the CSA well to define lithofacies based on mineralogy. Hupp (2017) collected $\mathrm{XRF}$, XRD, and Sm-Nd radiogenic isotope data on the MSEEL well to assess the provenance of the sediment. Lastly, Paronish (2018) collected handheld XRF data on the MSEEL well to assess lithofacies. Due to the sampling by Core Laboratories and Wonnell (2015), the highest TOC core locations in the CSA and Armstrong \#1 cores were not available for sampling; therefore representative sampling of the exceptionally high TOC could not be done. Alternatively, a regular interval sampling was conducted. 


\subsection{Sampling}

\subsubsection{Coldstream Affiliates 1MH Core (37-033-26848)}

Ten core chips (approximately 4 inches in diameter and 1 inch thick) acquired from the CSA well, housed at the National Energy and Technology Laboratory in Morganton, West Virginia, include two samples from the Union Springs Member of the Marcellus Shale, two samples from the Oatka Member of the Marcellus Shale, and one sample from the twenty feet of the lowest Mahantango Formation. (Fig. 4). Five of these sampled intervals were split and used for ICP-MS, Sm-Nd isotopic analysis, and thin section creation. Five samples were collected for laser Raman spectroscopic analysis at different depths to match the depths that vitrinite reflectance was previously measured by Core Laboratories (Fig. 4).

\subsubsection{Armstrong \#1 Core (47-091-01116)}

Ten core chips (approximately 4 inches in diameter and 1 inch thick) acquired from the Armstrong \#1 well, at the West Virginia Geological and Economic Survey in Morganton West Virginia, include one sample from the Union Springs Member of the Marcellus Shale, two samples from the Oatka Member of the Marcellus Shale, and two samples from the thirty feet of the lowest Mahantango Formation. (Fig. 5). Five of these sampled intervals were split and used for ICP-MS, Sm-Nd isotopic analysis, and thin section creation. Five samples were collected for laser Raman spectroscopic analysis at different depths to match the depths that vitrinite reflectance was previously measured by Core Laboratories (Fig. 4).

\subsubsection{MIP-3H Core (47-061-01705)}

In addition, five core cuttings samples (approximately 1 inch by 1 inch) were collected from the MSEEL well to assess thermal maturity using laser Raman spectroscopic analysis, 
which would allow for evaluation of thermal influence on TOC and provenance signatures of the CSA, Armstrong \#1, and MSEEL wells (Fig. 4).

\subsection{Analytical Methods}

\subsubsection{Samarium-Neodymium (Sm-Nd) Isotopic Analysis}

Five samples from both the CSA and Armstrong \#1 wells were analyzed for Sm and Nd isotopes by the University of Alabama. A VG Sector 54 Thermal Ionization Mass Spectrometer (TIMS) was used to measure the Sm and Nd isotopic concentrations. To prepare the samples, rock chips were powdered and spiked with a UNC (University of North Carolina) mixed spike for basalts UNC 'B'. The ratio is $400 \mathrm{ul} /$ [ $50 \mathrm{mg}$ ] of rock. The samples were then mixed with hydrofluoric acid to dissolve the silicate minerals. To get complete separation of the elements and to concentrate the Nd and Sm, three ion chromatographic column steps are conducted. After the third step, the Nd and Sm isotope quantities can be analyzed on the TIMS.

The Sm and Nd isotopic concentrations are used to calculate the depleted mantle model age ( $\boldsymbol{\tau}_{\mathrm{DM}}$; Eq. 1) and its epsilon neodymium ( $\varepsilon_{\mathrm{Nd}}$; Eq. 2) values (DePaolo and Wasserburg, 1976; Eq. 2). The $\lambda$ represents the decay of ${ }^{147} \mathrm{Sm}$ into ${ }^{143} \mathrm{Nd}$, which is $6.54 \times 10^{-12}$ per year (DePaolo, 1981). The ratio of ${ }^{143} \mathrm{Nd} /{ }^{144} \mathrm{Nd}$ for the current day depleted mantle is about 0.51315 (DePaolo,

1981). The ratio of ${ }^{147} \mathrm{Sm} /{ }^{144} \mathrm{Nd}$ is about 0.2137 for the current day depleted mantle. ${ }^{143} \mathrm{Nd} /{ }^{144} \mathrm{Nd}$ in a chondritic uniform reservoir (CHUR) is 0.512638. 


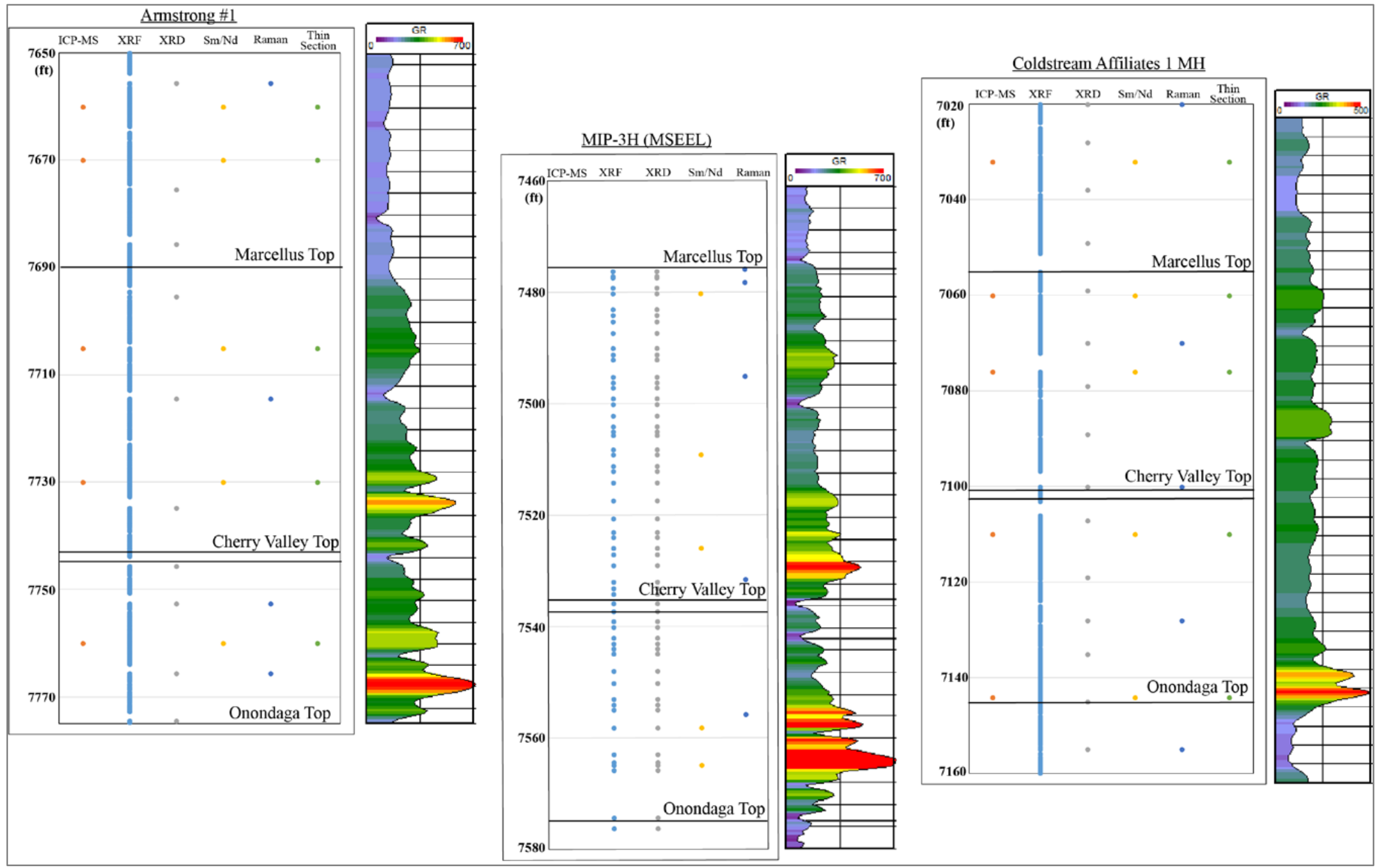

Figure 4. Sampling density of the Armstrong \#1, MSEEL, and CSA wells for the various analytical methods. ICP-MS, Sm-Nd radiogenic isotopes, laser Raman spectroscopic analysis, and thin section creation are from this study. XRF data is from Paronish (2018) and XRD is from Core Laboratories. A gamma ray (GR) geophysical log is plotted to the right and corresponds to the depths of sampling. Wells are plotted from south (left side) to north (right side). 
The $\varepsilon_{\text {Nd }}$ values mainly reflect type origin of the crust; the more negative values indicate a more felsic or chemically evolved crust, and the more positive values indicate a more mafic or chemically juvenile crust. Due to the immobile nature of Sm and $\mathrm{Nd}$, isotopic concentrations are not significantly affected by fluids during sedimentary transport and diagenesis (Nelson and DePaolo, 1988; Lipin et al., 1989); however $\varepsilon_{\mathrm{Nd}}$ values are even more robust as they reflect variation in Nd isotopic ratios, which would not be influenced by mass-dependent fractionation during sediment alteration processes (Feng et al., 2009).

Eq. 1

$$
\tau_{D M}={ }_{\lambda}^{1} \ln \left[\left(\frac{{ }^{143} \mathrm{Nd} /{ }^{144} \mathrm{Nd} \text { sample }-{ }^{143} \mathrm{Nd} /{ }^{144} \mathrm{Nd} \text { depleted mantle }}{{ }^{147} \mathrm{Sm} /{ }^{144} \mathrm{Nd} \text { sample }-{ }^{147} \mathrm{Sm} /{ }^{144} \mathrm{Nd} \text { depleted mantle }}\right)+1\right]
$$

Eq. 2

$$
\varepsilon_{N d}=\left(\frac{{ }^{143} N d /{ }^{144} N d \text { sample }-{ }^{143} N d /{ }^{144} N d C H U R}{{ }^{143} N d /{ }^{144} N d C H U R}\right) X 10000
$$

\subsubsection{Inductively Coupled Plasma Mass Spectroscopy (ICP-MS)}

Five whole-rock samples from each the CSA and Armstrong \#1 wells were analyzed for their major, trace, and rare earth element (REE) geochemistry using an ICP-MS (inductively coupled plasma mass spectrometer) at Activation Laboratories in Ancaster, Ontario. The ICPMS measured fifty-seven elemental concentrations. Each sample was at least $5 \mathrm{~g}$ (to ensure homogeneity) and was crushed to 200 mesh using an A Spex Shatterbox with steel containers. The samples were then sent to Actlabs where a lithium metaborate/tetraborate fusion was performed on each sample prior to ICP-MS analysis. 


\subsubsection{Laser Raman Spectroscopic Analysis}

Thermal maturity of core chips was assessed using a Laser Raman spectrometer, a method that is currently being developed (Lupoi et al., 2017; Lupoi et al., 2018). The thermal maturity was measured by using Raman spectrographic signatures of the relationship between peaks of the carbon-carbon double/single bonds. Five intervals from the CSA and the Armstrong \#1 well, with vitrinite reflectance already measured by Core Laboratories, were analyzed using a Horiba LabRAM Raman spectrometer at RJ Lee Group in Monroeville, Pennsylvania. Five additional intervals from the MSEEL well that did not have vitrinite reflectance determined were analyzed as well. Raman spectral acquisition used a $473 \mathrm{~nm}$ blue laser, an ND filter of 1\%, grating of 600 grooves/mm, with a pinhole size of $200 \mu \mathrm{m}$. Two accumulations were acquired over an acquisition time of five seconds. Ten different locations were analyzed per core chip and averaged together into one spectrum. Averaging Raman spectra for thermal maturity evaluation has been done in the past (Rahl et al., 2005; Bonoldi et al., 2016; Lupoi et al., 2017; Lupoi et al., 2018). This is a technique that is currently being developed (Lupoi et al., 2017; Lupoi et al., 2018) and is similar to the ASTM method 7708-14 used for vitrinite reflectance, where the average value of vitrinite reflectance is taken from 20-30 individual measurements at a specific well depth.

Many studies have used laser Raman spectroscopy to look at the relationship between the carbon-carbon single/double bonds and thermal maturity (Ferrari and Robertson, 2000; Liu et al., 2013; Lünsdorf, 2016; Lupoi et al., 2017; and Schito et al., 2017). Results from these studies have showed that, with an increase in thermal maturity, the two main peaks representing the carbon-carbon bonds changed. Namely, the locations of the G-band (right peak, $1600 \mathrm{~cm}^{-1}$ ) and D-band (left peak, $1350 \mathrm{~cm}^{-1}$ ) shift further away from each other, with increase in thermal 
maturity (Liu et al., 2013). This relationship was used to detect thermal maturity differences among the Armstrong \#1, Coldstream, and MSEEL wells. To identify the G- and D-bands, peak fitting must be performed on the Raman spectra. The software suite LabSpec 6 by Horiba was used to peak fit the spectra. A six-peak fit with a mixed Gaussian-Lorentzian band profile was used on the spectra to identify the G- and D-bands (Appendix VII). The lower wavenumber Raman peak, which usually occurs around $1350 \mathrm{~cm}^{-1}$, is assigned as the D-band. The higher wavenumber Raman peak, which usually occurs around $1600 \mathrm{~cm}^{-1}$, is assigned the G-band.

\subsubsection{Thin-Section Petrography}

Five samples each from the CSA and Armstrong \#1wells were sent to National Petrographic Service, Inc. for standard polished thin-section preparation using clear epoxy. The thin sections were not oriented with respect to "stratigraphic up”. The ten total thin sections were analyzed using a Nikon Eclipse LV100PDL microscope. Photomicrographs of the thin sections were taken using a Nikon DS-Fi1 and analyzed using NIS Elements Imaging Software developed by Nikon. Observations such as grain size, grain shape, mineralogy, sedimentary structures, and fossil content were recorded. The different depths were then classified according to the classification scheme from Milliken (2014). This scheme separates fine-grained sedimentary rocks according to the origin of the sediment. There are three grain assemblage classifications: tarls, sarls, and carls. The presence of over $75 \%$ predominantly terrigenous components are tarls. Rocks with the presence of $>25 \%$ intrabasinal bio-siliceous grains are sarls. Rocks with the presence of $>25 \%$ biogenic carbonate particles, such as calcareous mudstones, are carls. 


\section{Results}

\subsection{Geochemical Results}

\subsubsection{Samarium-Neodymium (Sm-Nd) Isotopic Analysis}

The $\boldsymbol{\tau}_{\mathrm{DM}}$ and $\varepsilon_{\mathrm{Nd}}$ are calculated from ${ }^{147} \mathrm{Sm},{ }^{144} \mathrm{Nd}$, and ${ }^{143} \mathrm{Nd}$ using Equations 1 and 2. The results Sm-Nd analysis for samples from Armstrong \#1 and CSA wells are shown in Table 2. The $\varepsilon_{\mathrm{Nd}}$ values from the Armstrong \#1 core samples range from -9.56 to -11.83 and the $\boldsymbol{\tau}_{\mathrm{DM}}$ values range from 1.64 to $1.91 \mathrm{Ga}$. In the CSA core, $\varepsilon_{\text {Nd }}$ values are more negative, and range from -11.12 to -12.07 . The $\boldsymbol{\tau}_{\mathrm{DM}}$ values from the CSA are similar, and range from 1.62 to $1.88 \mathrm{Ga}$. In the CSA well the oldest $\boldsymbol{\tau}_{\mathrm{DM}}$ ages are within the Mahantango Formation whereas the oldest $\boldsymbol{\tau}_{\mathrm{DM}}$ ages of the Armstrong \#1 well are in the Oatka Creek Member of the Marcellus Shale. The $\varepsilon N d$ trends within the CSA well stayed relatively constant (-11.12 to -12.07$)$ throughout the Marcellus Shale and Lower Mahantango while the Armstrong \#1 عNd trended more negative with decrease in depth (-9.56 to -11.83$)$.

Table 2. Sm-Nd isotopic data of the Armstrong \#1 and CSA wells.

\begin{tabular}{|c|c|c|c|c|c|}
\hline \multicolumn{3}{|c|}{ Armstrong \#1 } & \multicolumn{3}{c|}{ CSA } \\
\hline Depth & $\boldsymbol{\varepsilon}_{\mathbf{N d}}$ & $\boldsymbol{\tau}_{\mathbf{D M}} \mathbf{G a}$ & Depth & $\boldsymbol{\varepsilon}_{\mathbf{N d}}$ & $\boldsymbol{\tau}_{\text {DM Ga }}$ \\
\hline $\begin{array}{c}\text { Mahantango } \\
7660\end{array}$ & -11.83 & 1.65 & $\begin{array}{c}\text { Mahantango } \\
7032\end{array}$ & -11.61 & 1.88 \\
\hline $\begin{array}{c}\text { Mahantango } \\
7670\end{array}$ & -11.45 & 1.64 & $\begin{array}{c}\text { Oatka Creek } \\
7060\end{array}$ & -11.12 & 1.84 \\
\hline $\begin{array}{c}\text { Oatka Creek } \\
7705\end{array}$ & -11.20 & 1.80 & $\begin{array}{c}\text { Oatka Creek } \\
7075\end{array}$ & -12.07 & 1.62 \\
\hline $\begin{array}{c}\text { Oatka Creek } \\
7730\end{array}$ & -10.05 & 1.91 & $\begin{array}{c}\text { Union Springs } \\
7110\end{array}$ & -11.43 & 1.68 \\
\hline $\begin{array}{c}\text { Union Springs } \\
7760\end{array}$ & -9.56 & 1.76 & $\begin{array}{c}\text { Union Springs } \\
7144\end{array}$ & -11.39 & 1.76 \\
\hline
\end{tabular}

Notes: ${ }^{143} \mathrm{Nd} /{ }^{144} \mathrm{Nd} 2 \sigma=9 \times 10^{-6} ;{ }^{147} \mathrm{Sm} /{ }^{144} \mathrm{Nd} 2 \sigma=9 \times 10^{-4} ; \boldsymbol{\tau}_{\mathrm{DM}}$ calculated from Eq. $1 ; \varepsilon N d$ calculated from Eq. 2; Total error in $\boldsymbol{\tau}_{\mathrm{DM}}+/-1 \mathrm{Ma}$; Total error in $\varepsilon \mathrm{Nd}+/-0.18$. 


\subsubsection{Trace element and REE Geochemistry}

A few noticeable trends can be seen from the major and trace element concentrations in the ICP-MS data (Appendix I). The deepest Armstrong \#1 sample (A-7760) is anomalous in its major and trace element concentrations. Within this sample, there are higher amounts of $\mathrm{CaO}, \mathrm{Sr}$, and $\mathrm{Y}$ while lower $\mathrm{SiO}_{2}, \mathrm{Al}_{2} \mathrm{O}_{3}$, and $\mathrm{Zr}$ relative to all other Armstrong \#1 and CSA samples. Generally, concentrations of $\mathrm{MgO}$ and $\mathrm{MnO}$ decrease while $\mathrm{Ni}, \mathrm{Cu}$, and $\mathrm{Zn}$ increase with greater depth within both the Armstrong \#1 and CSA samples.

Major element abundances were used to evaluate the composition of the rocks in the source area using discrimination equations from Roser and Korsch (1988) (Eq. 3 and 4; Fig. 5). Discrimination diagrams of major element geochemistry show that the major element geochemical composition of most samples is consistent with a quartzose sedimentary or intermediate igneous source rock, with 2 samples reflecting a felsic igneous source (Figure 5). Major element ternary plots indicate moderate modification to major elemental composition from chemical weathering (Fig. 7-9).

Eq. $3 \quad \mathrm{DF} 1=-1.773 \mathrm{TiO}_{2}+0.607 \mathrm{Al}_{2} \mathrm{O}_{3}+0.76 \mathrm{Fe}_{2} \mathrm{O}_{3}(\mathrm{t})-1.5 \mathrm{MgO}+0.616 \mathrm{CaO}+$ $0.509 \mathrm{Na}_{2} \mathrm{O}-1.22 \mathrm{~K}_{2} \mathrm{O}-9.09$

Eq. $4 \quad \mathrm{DF} 2=0.445 \mathrm{TiO}_{2}+0.07 \mathrm{Al}_{2} \mathrm{O}_{3}-0.25 \mathrm{Fe}_{2} \mathrm{O}_{3}(\mathrm{t})-1.142 \mathrm{MgO}+0.438 \mathrm{CaO}+$ $1.426 \mathrm{~K}_{2} \mathrm{O}-6.861$

Ternary plots of selected major elements (Fig. 6 and 7; Nesbitt and Young, 1982), along with trace element and REE abundances (Fig. 8 and 9; McLennan et al., 1993) were used to determine sediment source rock compositions. Figures 6-9 show that the source of the sediments has an upper continental crustal signature, specifically a felsic granitic source. 


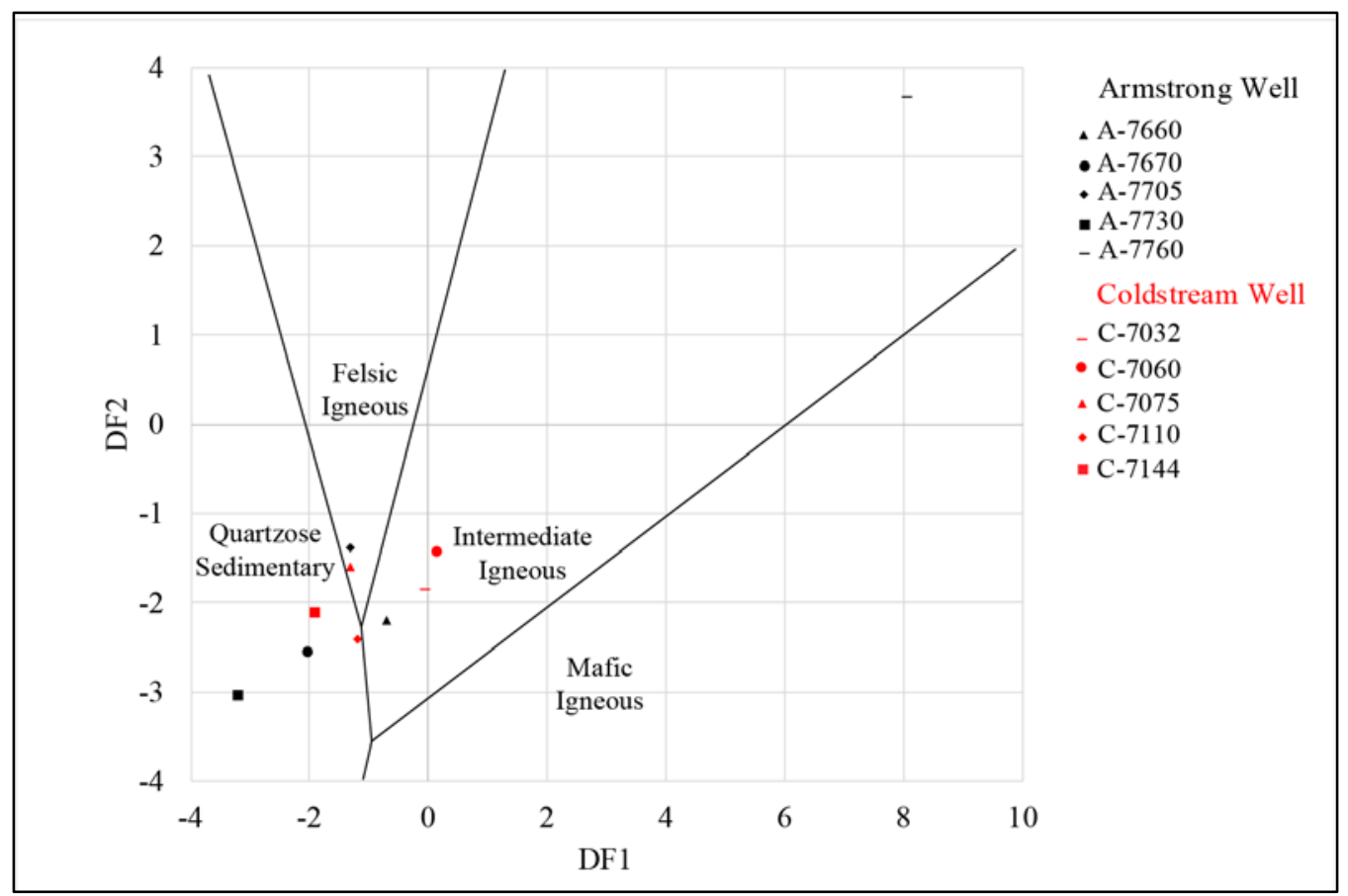

Figure 5. Sediment source discrimination diagram, which determines the source of the sediment. Equation 3 is DF1 and Equation 4 is DF2 (Roser and Korsch, 1988).

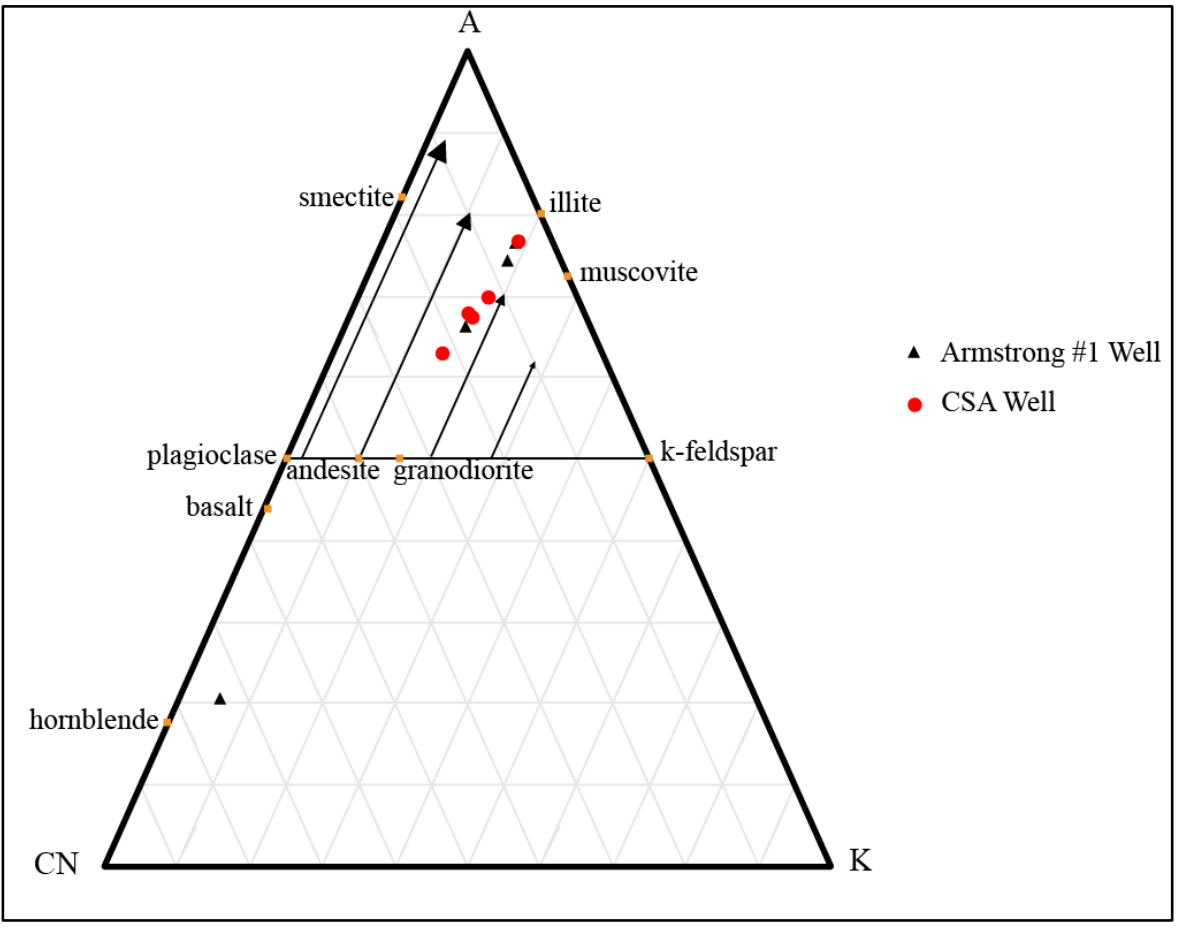

Figure 6. Aluminum (A), calcium and sodium (CN), and potassium (K) elemental concentrations are used to plot source compositions according to Nesbitt and Young (1982). Results indicate weathering from an upper continental crust. 


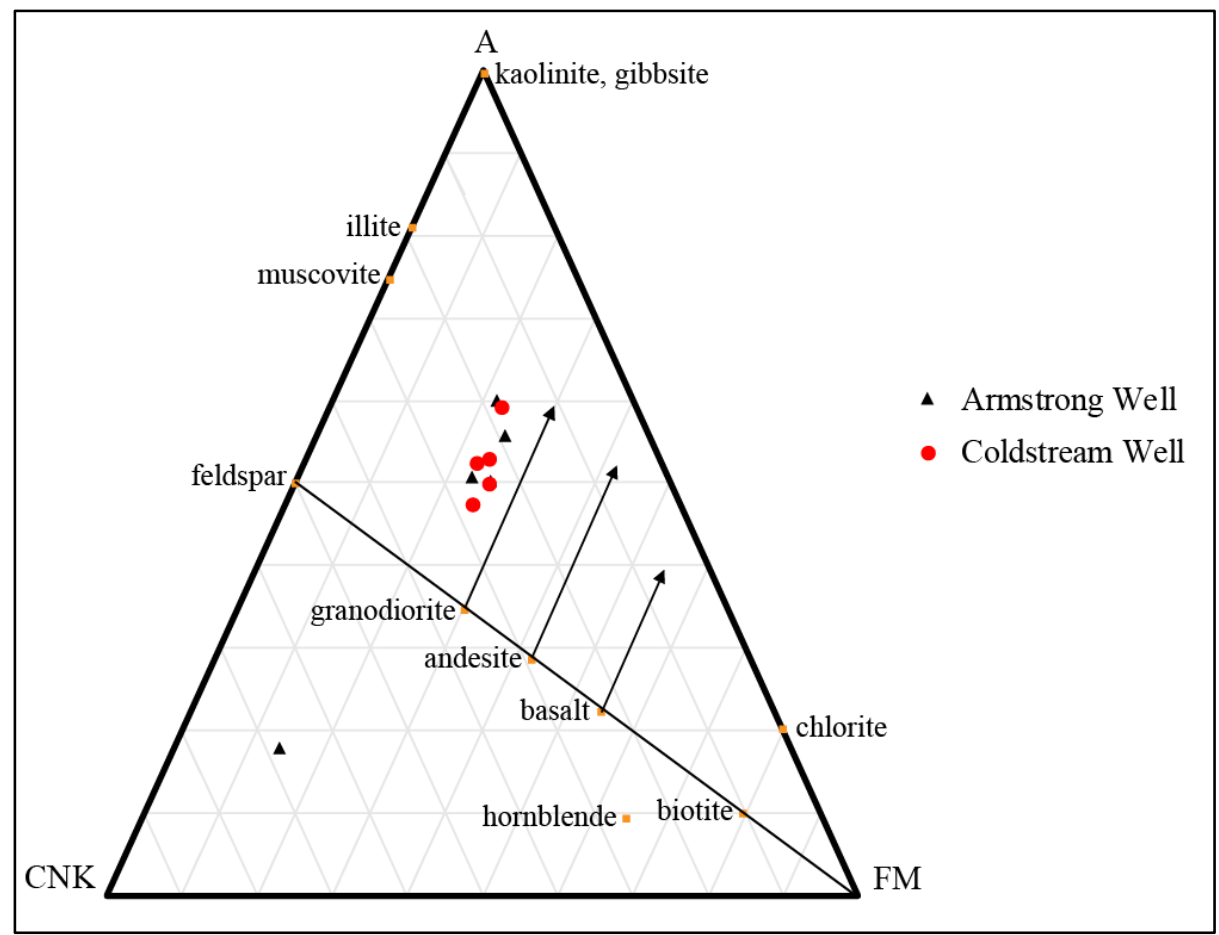

Figure 7. Aluminum (A), calcium, sodium, and potassium (CNK), and iron and magnesium (FM) elemental concentrations are used to plot source compositions according to Nesbitt and Young (1982). Results indicate weathering from an upper continental crust.

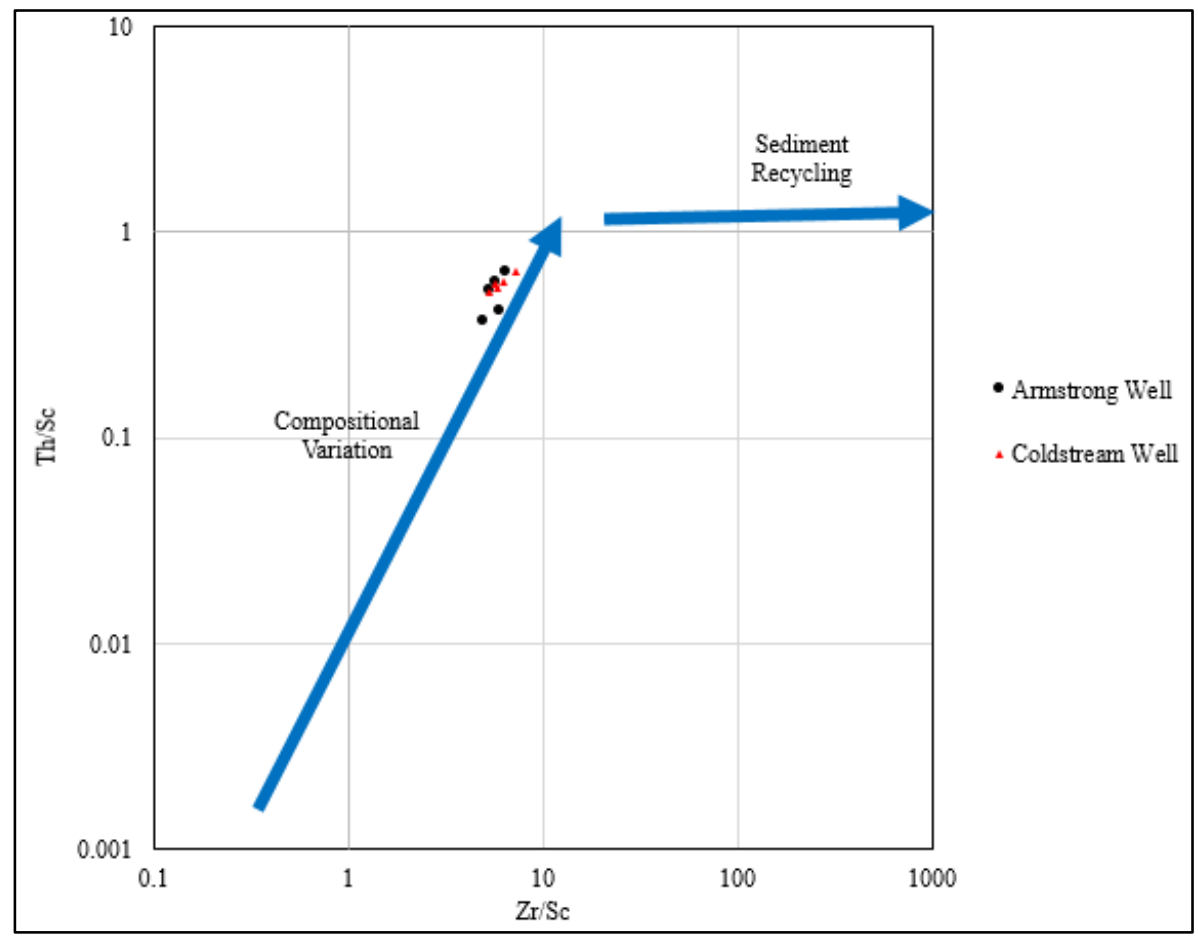

Figure 8. Concentrations of thorium, zirconium, and scandium determined if the sediment source was from recycled sediment or not, according to McLennan et al. (1993). 


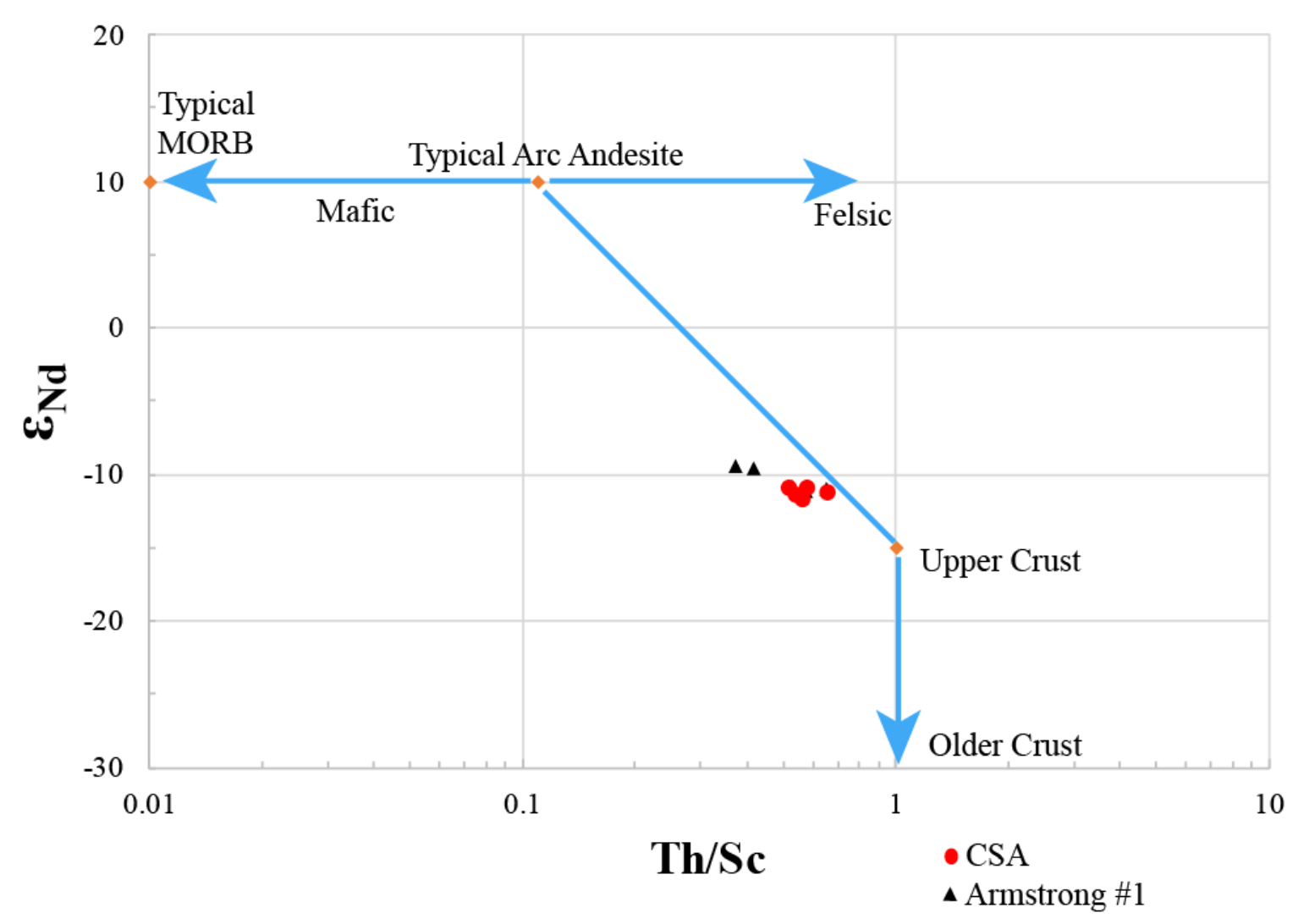

Figure 9. $\varepsilon \mathrm{Nd}$ vs. Th/Sc ratio indicates the provenance source type of the sediments that make up core samples from the CSA and Armstrong \#1 wells. Adapted from McLennan et al. (1993).

Abundances of REEs normalized to chondrite (McDonough and Sun, 1995; Fig. 10) reveal overall similar distribution patterns for Armstrong and CSA samples. All samples show light REE enrichment compared to heavy REE and all samples have a negative Eu-anomaly ranging from 0.21 to 0.24 . The deepest Armstrong \#1 well sample (7760 ft.) showed greatest enrichment in REE with $\Sigma$ REE $=324 \mathrm{ppm}$ compared to the average $\Sigma$ REE of $179 \mathrm{ppm}$ for all other Armstrong \#1 samples. The shallowest Armstrong \#1 well sample (7660 ft.) was the least enriched in REE with the $\Sigma$ REE $=174 \mathrm{ppm}$. Overall the REE abundances are consistent with a felsic, chemically evolved upper continental crust source rock lithology for the Armstrong \#1 well (McLennan, 2001). 
Similar to the Armstrong well, the deepest CSA well sample (7144 ft.) was most enriched REE with $\Sigma$ REE = $195 \mathrm{ppm}$; this is greater than other CSA samples which yield an average $\Sigma$ REE of $181 \mathrm{ppm}$. The lowest value for the $\Sigma$ REE did not occur in the shallowest depth of the CSA well, rather it occurred within the top of the Union Springs member (7110 ft.). The disparity between the largest and smallest $\Sigma$ REE in the CSA well is not as great as in the Armstrong \#1 well, however. Overall, similar to the Armstrong \#1 well, the REE abundances are consistent with a felsic, chemically evolved source rock lithology for the CSA well. Both wells suggest a decrease in $\Sigma$ REE upsection from the basal samples, potentially due to early influx from a highly felsic source followed by mixing of a less chemically evolved source.

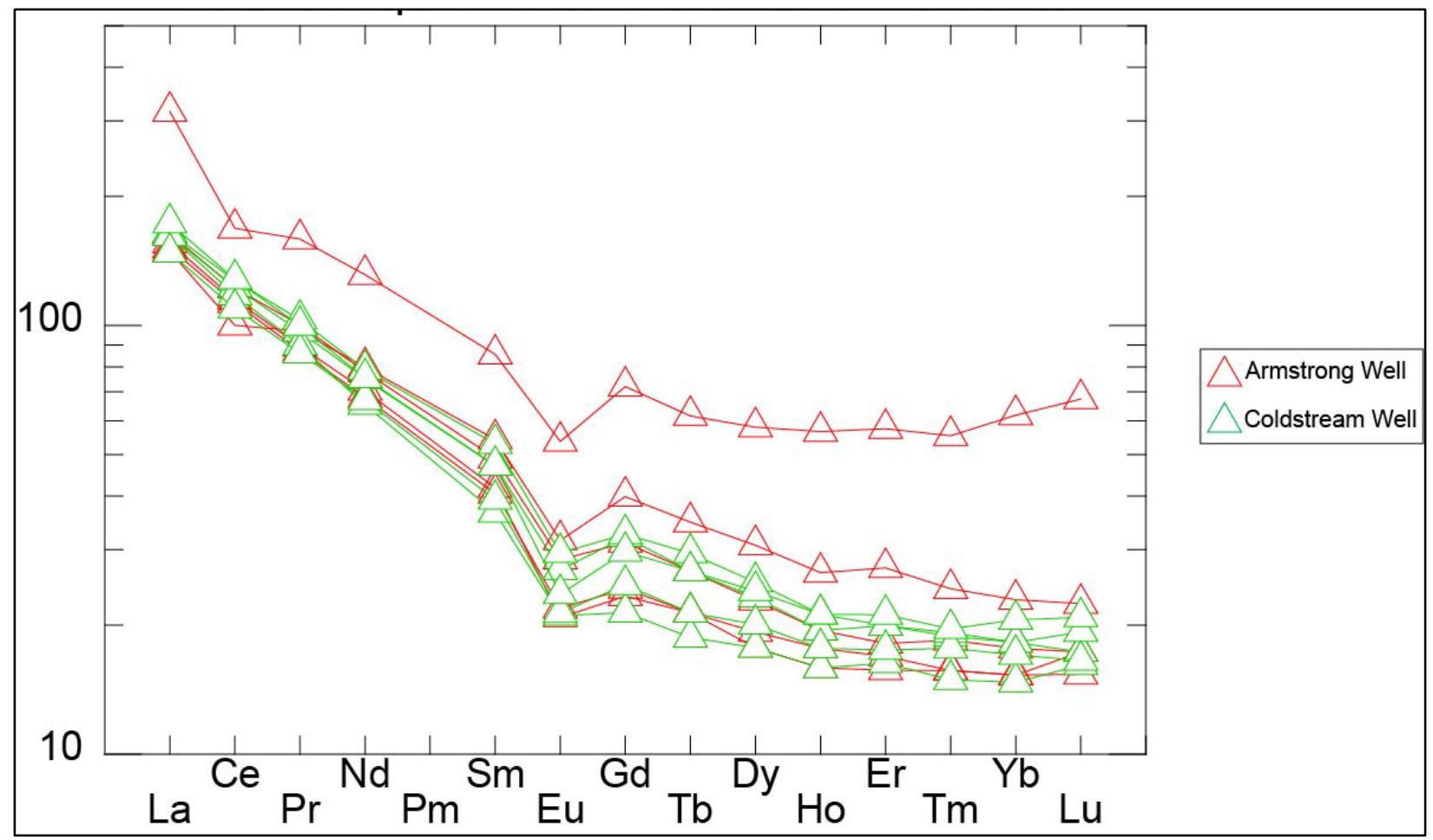

Figure 10. REEs in the Armstrong \#1 and CSA wells. The deepest Armstrong \#1 sample (7760 $\mathrm{ft}$. ) is isolated from other samples. 


\subsubsection{Thermal Maturity from Laser Raman Spectroscopic Analysis}

All samples analyzed by laser Raman spectroscopy resulted in Raman spectra with at least two distinct, but broad peaks. One wide, low peak was observed around $1350 \mathrm{~cm}^{-1}$. A slightly sharper and taller peak was observed around $1600 \mathrm{~cm}^{-1}$. Each well depth's ten spectra acquired can be seen in Appendix VI. The ten spectra are averaged to one spectrum, a technique developed in Lupoi et al. (2017) and is still currently being developed (Lupoi et al., 2018; Lupoi et al., in review). The results for each well are shown in Figure 11. The averaged spectra are peak fit to a 6-peak fit and the G- and D-band locations are found. The G- and D-band separations are listed in Table 3 below.

Table 3. G-D band separation from various depths within the MSEEL, Coldstream, and Armstrong \#1 wells.

\begin{tabular}{|c|c|c|c|c|c|}
\hline \multicolumn{2}{|c|}{ MSEEL } & \multicolumn{2}{|l|}{ Coldstream } & \multicolumn{2}{|c|}{ Armstrong \#1 } \\
\hline Depth & G - D & Depth & G - D & Depth & G - D \\
\hline $\begin{array}{c}\text { Oatka Creek } \\
7475\end{array}$ & 252.19 & $\begin{array}{l}\text { Lower Mahantango } \\
7019\end{array}$ & 252.27 & $\begin{array}{l}\text { Lower Mahantango } \\
7605\end{array}$ & 247.95 \\
\hline $\begin{array}{c}\text { Oatka Creek } \\
7477\end{array}$ & 252.48 & $\begin{array}{c}\text { Oatka Creek } \\
7070\end{array}$ & 254.50 & $\begin{array}{l}\text { Lower Mahantango } \\
7655\end{array}$ & 248.91 \\
\hline $\begin{array}{c}\text { Oatka Creek } \\
7494\end{array}$ & 251.25 & $\begin{array}{c}\text { Oatka Creek } \\
7099\end{array}$ & 254.50 & $\begin{array}{c}\text { Oatka Creek } \\
7714\end{array}$ & 251.05 \\
\hline $\begin{array}{c}\text { Oatka Creek } \\
7534\end{array}$ & 247.39 & $\begin{array}{c}\text { Union Springs } \\
7128\end{array}$ & 249.96 & $\begin{array}{c}\text { Union Springs } \\
7752\end{array}$ & 249.54 \\
\hline $\begin{array}{c}\text { Union Springs } \\
7556 \\
\end{array}$ & 250.00 & $\begin{array}{c}\text { Onondaga Limestone } \\
7155 \\
\end{array}$ & 249.25 & $\begin{array}{c}\text { Union Springs } \\
7765 \\
\end{array}$ & 249.39 \\
\hline $\begin{array}{l}\text { Average } \\
\text { St. Dev. }\end{array}$ & $\begin{array}{c}250.66 \\
1.85 \\
\end{array}$ & $\begin{array}{l}\text { Average } \\
\text { St. Dev. }\end{array}$ & $\begin{array}{c}252.10 \\
2.20 \\
\end{array}$ & $\begin{array}{l}\text { Average } \\
\text { St. Dev. }\end{array}$ & $\begin{array}{c}249.37 \\
1.40 \\
\end{array}$ \\
\hline
\end{tabular}

The largest band separation (between the G- and D-bands) occurs in the CSA well while the smallest separation occurs in the Armstrong \#1 well. The larger the band separation, the higher the thermal maturity value (Liu et al., 2013), therefore the CSA well records the highest thermal maturity and the Armstrong \#1 well records the lowest thermal maturity, respectively. 
The $\mathrm{VR}_{0} \%$ estimates for the Armstrong and MSEEL are around 2\% and the estimates for the CSA well are around 2.4\% (Liu et al., 2013; Sauerer et al., 2017). Although a more robust quantitative assessment was not performed on the spectra for these samples, this semiquantitative approach shows that the CSA well reflects a slightly higher thermal maturity of the study wells due to the largest band separation. It is worth mentioning that the lowest band separation value in the CSA well occurs in the Onondaga Limestone, an organic-poor formation, which may affect the Raman spectrum. With the Onondaga Limestone sample removed, the average band separation in the CSA well is 252.81 with a standard deviation of 1.88 . The band separations determined from Raman spectra appear to be positively correlated with $\mathrm{VR}_{0} \%$. An empirical relationship can be defined with further statistical modeling, that is beyond the scope of this thesis.

\subsection{Thin-Section Petrography}

Full results of the thin-section petrography are located in Appendix II. Textural maturity of detrital quartz grains decreases upsection, with more larger and more angular quartz silt grains present upsection in both the Armstrong \#1 and CSA wells (Fig. 12). Sorting of the grains is moderately well sorted throughout all samples. Clays are most abundant in the shallowest intervals of the Mahantango Formation compared to the underlying Marcellus Shale. Within the Marcellus Shale, the prevalence of pyrite and biogenic silica (based on the increase in siliceous fossils and irregular silica masses) becomes more frequent than the Mahantango Formation, especially within the Union Springs Member. Notably, there were more laminations upsection in both the Armstrong \#1 and CSA wells. Most of the mudstone samples are tarls according to the Milliken (2014) classification (Table 4); however, the deepest samples from both the Armstrong \#1 and CSA wells were argillaceous sarls. 

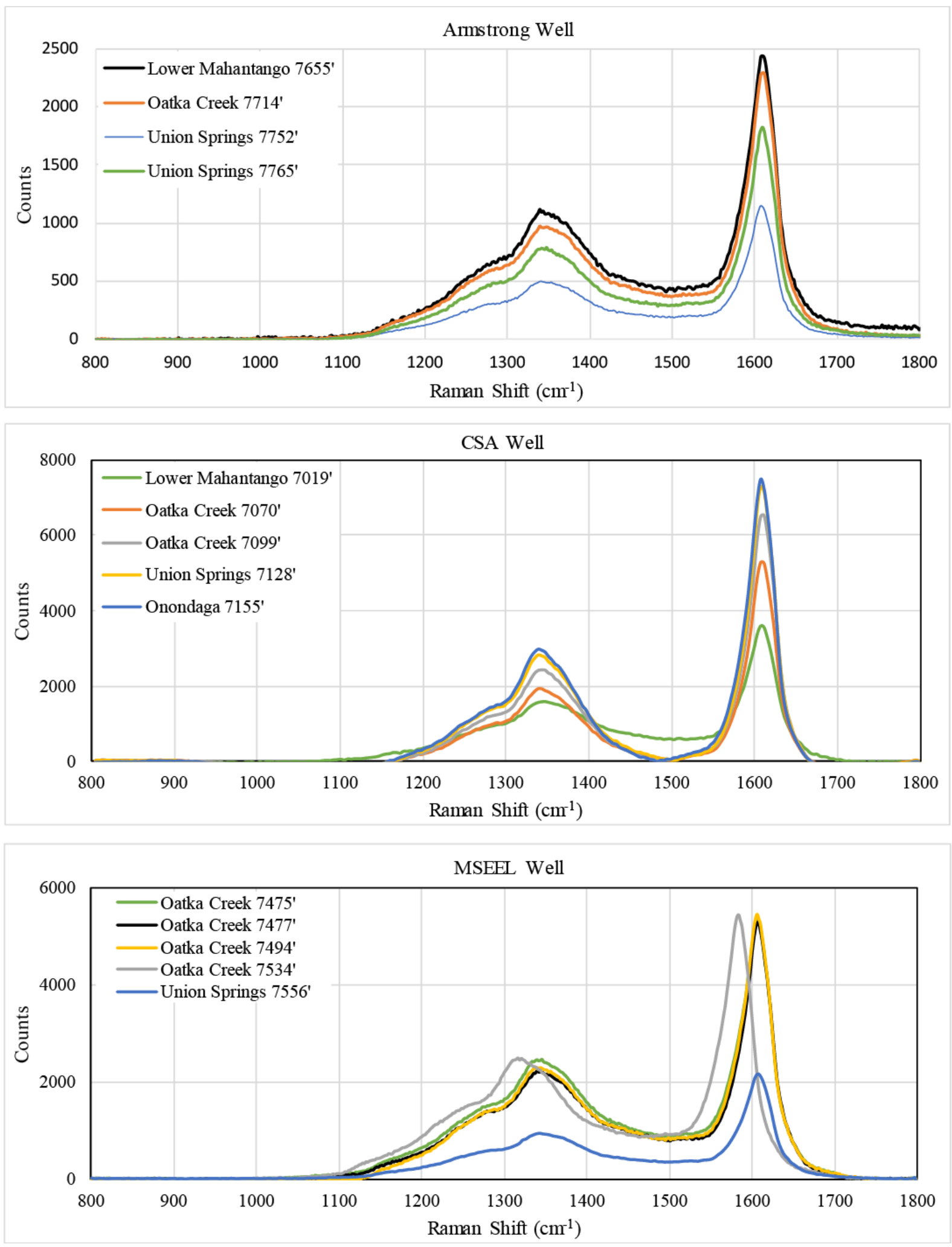

Figure 11. Armstrong \#1, CSA, and MSEEL well laser Raman spectra. Spectra are baseline corrected and averaged at each depth from ten individual spectra. 
Table 4. Classifications of the thin sections in both the Armstrong \#1 and CSA wells according to Milliken (2014).

\begin{tabular}{|c|c|}
\hline Sample ID & Milliken (2014) Classification \\
\hline A-7660 & calcareous tarl \\
\hline A-7670 & siliceous tarl \\
\hline A-7705 & siliceous tarl \\
\hline A-7730 & siliceous tarl \\
\hline A-7760 & argillaceous carl \\
\hline C-7032 & siliceous tarl \\
\hline C-7060 & calcareous tarl \\
\hline C-7075 & argillaceous sarl \\
\hline C-7110 & argillaceous sarl \\
\hline C-7144 & argillaceous sarl \\
\hline
\end{tabular}
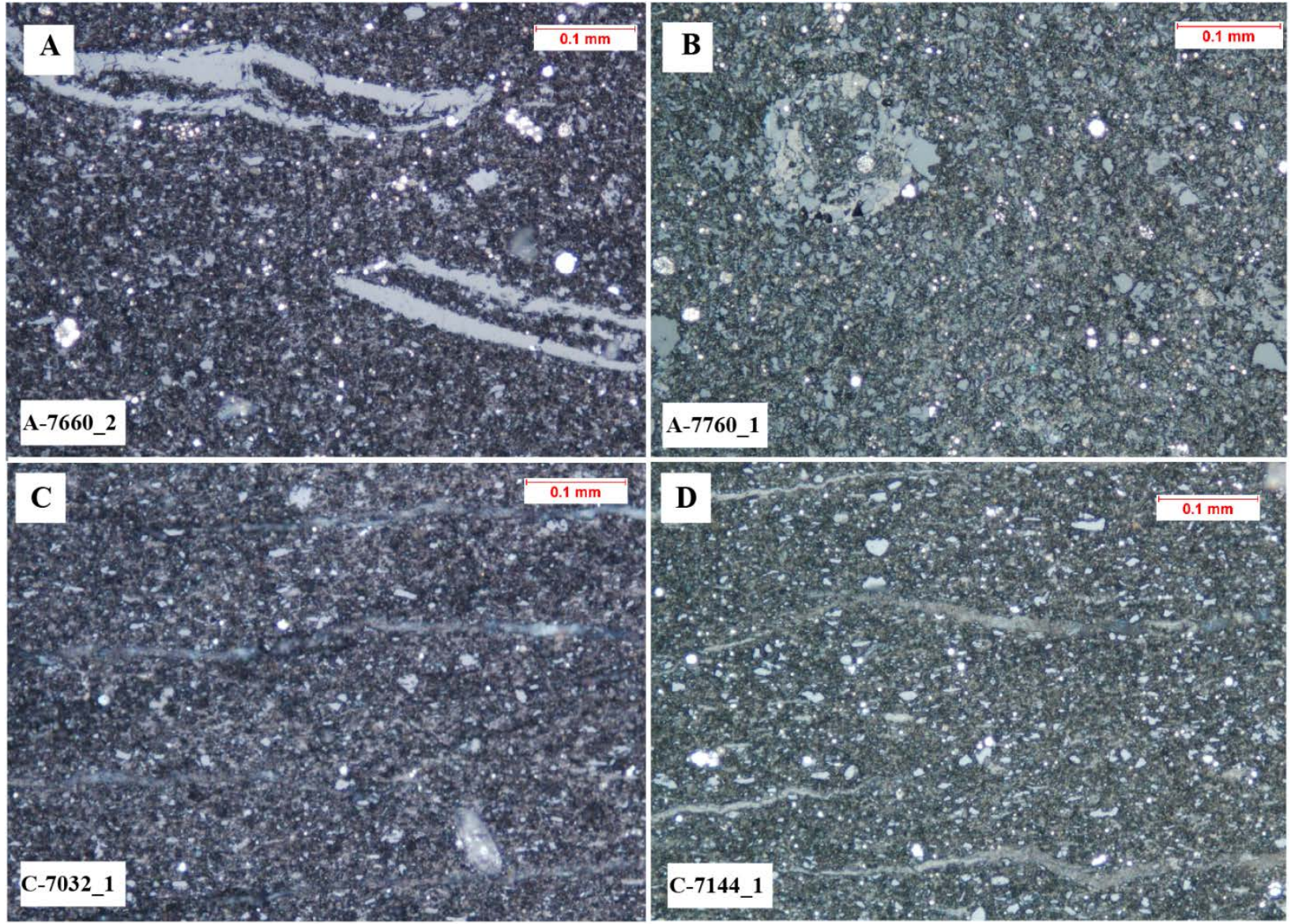

Figure 12. Thin sections from the Lower Mahantango (A \& C) and Union Springs Member (B \& D). A and B are from the Armstrong \#1 well and C and D are from the CSA well. 


\section{Discussion}

Four potential sources of the sediments make up the Hamilton group: the Acadian FoldThrust Belt, the Acadian Arc, the Superior Craton, and the southern Canadian Grenville Province, and (Fig. 1; Table 5).

\subsection{Geochemistry of Potential Sediment Sources}

Acadian Fold-Thrust Belt: The Acadian Fold-Thrust Belt formed to the east (modern coordinates) of the Acadian Basin and uplifted during the Acadian orogeny (Ettensohn, 1985). It contained late Proterozoic Grenvillian felsic orogenic rocks (Tollo et al., 2004), Early Paleozoic passive margin strata, and Ordovician to Early Devonian Taconic foreland basin strata (Ryder et al., 2012). Within the Grenville felsic orogenic rocks $\boldsymbol{\tau}_{\mathrm{DM}}$ ranges from 1.6 to $1.4 \mathrm{Ga}$ and $\varepsilon_{\mathrm{Nd}}$ ranges from -5 to -13 (Patchett et al., 1999). It is enriched in REE, especially the light REE. Trace and REE ratios are seen in Table 5. The Taconic foreland strata, which was folded and eroded during the Acadian Orogeny, consisted of clastic sedimentary sequences, mostly limestones/dolostones and shales, some sandstones (Ryder et al., 2012). The $\boldsymbol{\tau}_{\mathrm{DM}}$ ranged from 1.6 to $2.2 \mathrm{Ga}$ and $\varepsilon_{\mathrm{Nd}}$ ranged from -9 to -20 (Bock et al., 1996; Eriksson et al., 2004).

Acadian Arc: The Acadian magmatic arc formed to the east (modern coordinates) of the Acadian Basin during the Middle Devonian Acadian Orogeny and contains felsic and intermediate granitic igneous rocks (Parrish 2013). The $\boldsymbol{\tau}_{\mathrm{DM}}$ ranges from 403-417 Ma and $\varepsilon_{\mathrm{Nd}}$ ranges from 4-2 (Schoonmaker et al., 2011). High $\mathrm{Cr} / \mathrm{Ni}$ ratios are measured from the somewhat chemically primitive crustal rocks that comprised the arc, and $\Sigma$ REE are lower compared to the other potential sources (Table 5; D’Hulst et al., 2008). 
Superior Craton: The Superior Craton is an amalgamation of igneous and metamorphic rocks that form the core of the North American continent and is exposed to the northwest (modern coordinates) of the Devonian Acadian Basin. It has been tectonically stable since the Precambrian (Canil, 2008). The craton contains upper crustal igneous rocks (Taylor et al., 1986) with $\boldsymbol{\tau}_{\mathrm{DM}}$ ranging from 2.7 to $3.1 \mathrm{Ga}$ and $\varepsilon_{\mathrm{Nd}}$ less than -17 (Percival et al., 2006). $\mathrm{La} / \mathrm{Yb}$ ratios are higher than other source rocks, indicating an enrichment of LREE, and its Ti/Zr ratios are lower than other source rocks (Table 5).

Southern Canadian Grenville Province: The southern Canadian Grenville Province includes a series of accreted terranes northwest (modern coordinates) of the Devonian Acadian Basin. Lithologies consist of upper crustal igneous rocks and orthogneisses (Currie and Breemen, 1996; Prevec, 2004). The $\boldsymbol{\tau}_{\mathrm{DM}}$ ranges from 1.3-1.9 Ga and the $\varepsilon_{\mathrm{Nd}}$ ranges from -13 to -17 (Percival et al., 2006; McLelland et al., 2010). 2 REE and Zr/Sc are lowest and Ti/Zr are highest among all possible sources evaluated (Table 5).

\subsection{Hamilton Group Sediment Source Area Characterization: Lithology, and Geochemistry}

\subsubsection{Major, Trace, and REE Concentrations}

Results from this study indicate that the sediment source became more intermediate and less mature upsection (Table 6). The stratigraphic trends of $\mathrm{Si}$ and $\mathrm{Al}$ were used as proxies for quartz (Si) versus clay (Al) input in the lower Hamilton Group for the CSA, Armstrong \#1, and MSEEL wells (Fig. 13). Si/Al $<5$ indicates detrital dilution of sediments by clay-rich sediments instead of quartz grains (Ver Straeten et al., 2011). Results show that Si/Al slightly decreases upsection for all wells. The ratios of Si/Al are highest in the Union Springs Member and in the 
bottom of the Oatka Creek Member for the Armstrong \#1, CSA, and MSEEL wells, reflecting the lowest detrital dilution during most productive TOC (Fig. 14). This trend has been observed previously in Ver Straeten et al. (2011). Cross-plot of Si/Al vs. Zr/Al shows strong correlation, indicating no significant Si increases are due to biogenic silica (Fig. 15). To test for eolian influx, elemental trends of $\mathrm{Ti}$ and $\mathrm{Al}$ were used as proxies for eolian silt input. High values of $\mathrm{Ti} / \mathrm{Al}$ indicate eolian silt due to rutilated quartz being present in eolian deposits (Sageman et al., 2003). Results show that Ti/Al slightly decreases upsection (Fig. 13). Spikes of high Ti/Al are also seen in the Armstrong \#1 and CSA wells, which may also be instrumental collection errors.

REE abundances are consistent with a felsic, chemically evolved source rock lithology for the CSA and Armstrong \#1 wells. $\Sigma$ REE are around $200 \mathrm{ppm}$ for the Armstrong \#1 and CSA wells. La/Lu, which indicates the slope of REE from light REE to heavy REE, averages around 79, consistent with light REE enrichment. Furthermore, the Eu/Eu* (europium anomaly) averages around 0.23, which is typical for feldspathic felsic crustal rocks (McLennan et al., 1993). 
Table 5. Elemental and lithological descriptions of the Armstrong \#1, CSA, and source possibilities.

\begin{tabular}{|c|c|c|c|c|c|c|c|}
\hline & Armstrong \#1 & CSA & $\begin{array}{l}\text { Southern } \\
\text { Canadian } \\
\text { Grenville } \\
\text { Province }\end{array}$ & $\begin{array}{l}\text { Grenville } \\
\text { Inliers (b) }\end{array}$ & $\begin{array}{l}\text { Taconic } \\
\text { Foreland } \\
\text { Strata }(c)\end{array}$ & $\begin{array}{l}\text { Superior } \\
\text { Craton (d) }\end{array}$ & Acadian $\operatorname{Arc}^{(e)}$ \\
\hline$\tau \mathrm{TM}$ & $\begin{array}{c}1.65 \text { to } 1.91 \\
\mathrm{Ga}\end{array}$ & 1.62 to $1.88 \mathrm{Ga}$ & 1.3 to $1.9 \mathrm{Ga}$ & 1.4 to $1.6 \mathrm{Ga}$ & 1.6 to $2.2 \mathrm{Ga}$ & $>2.7 \mathrm{Ga}$ & $450 \mathrm{Ma}$ \\
\hline$\varepsilon N d$ & -9.56 to -11.83 & $\begin{array}{c}-11.12 \text { to }- \\
12.07 \\
\end{array}$ & -12 to -17 & -5 to -13 & -9 to -20 & $>-17$ & 4 to 2 \\
\hline $\begin{array}{c}\text { Discrimination } \\
\text { Plot }\end{array}$ & $\begin{array}{l}\text { quartzose to } \\
\text { intermediate }\end{array}$ & $\begin{array}{l}\text { quartzose to } \\
\text { intermediate }\end{array}$ & $\begin{array}{c}\text { felsic to } \\
\text { intermediate }\end{array}$ & felsic & quartzose & felsic & $\begin{array}{c}\text { felsic to } \\
\text { intermediate }\end{array}$ \\
\hline Ternary Plots & $\begin{array}{l}\text { moderate } \\
\text { chemical } \\
\text { alteration } \\
\end{array}$ & $\begin{array}{l}\text { moderate } \\
\text { chemical } \\
\text { alteration } \\
\end{array}$ & $\begin{array}{l}\text { low chemical } \\
\text { alteration }\end{array}$ & $\begin{array}{c}\text { low chemical } \\
\text { alteration }\end{array}$ & $\begin{array}{l}\text { high chemical } \\
\text { alteration }\end{array}$ & $\begin{array}{l}\text { low chemical } \\
\text { alteration }\end{array}$ & $\begin{array}{l}\text { low chemical } \\
\text { alteration }\end{array}$ \\
\hline Th/Sc vs. Zr/Sc & upper crustal & upper crustal & upper crustal & upper crustal & $\begin{array}{l}\text { sediment } \\
\text { recycling }\end{array}$ & upper crustal & $\begin{array}{l}\text { mid to upper } \\
\text { crustal }\end{array}$ \\
\hline$\varepsilon N d$ vs. Th/Sc & upper crustal & upper crustal & upper crustal & upper crustal & $\begin{array}{l}\text { sediment } \\
\text { recycling }\end{array}$ & older crust & arc andesite \\
\hline इREE & 208 & 189 & 40 & 268 & 164 & 132 & 48 \\
\hline La/Lu & 74 & 84 & 68 & 103 & 9.65 & 20 & 25 \\
\hline Eu/Eu* & 0.23 & 0.23 & 0.19 & 0.34 & 0.2 & 0.49 & 0.3 \\
\hline $\mathrm{Cr} / \mathrm{Ni}$ & 0.74 & 1.05 & 0.84 & 2.5 & 1.78 & 1.84 & 2.51 \\
\hline $\mathbf{T i} / \mathrm{Zr}$ & 0.0058 & 0.0061 & 0.075 & 0.0015 & 0.0041 & 0.0013 & 0.011 \\
\hline $\mathbf{L a} / \mathbf{Y b}$ & 11.4 & 12.8 & 10.2 & 19.8 & 9.65 & 20 & 3.8 \\
\hline $\mathrm{Zr} / \mathrm{Sc}$ & 5.64 & 6.11 & 1.21 & 30 & 24.8 & 33.86 & 4.03 \\
\hline
\end{tabular}

Notes: (a) Prevec (2004); (b) Volkert et al. (2000) \& Tollo et al. (2004); (c) Bock et al. (1998) and Eriksson et al. (2004); (d) Taylor et al. (1986) \& McLennan (2001); (e) D’hulst et al. (2008) 


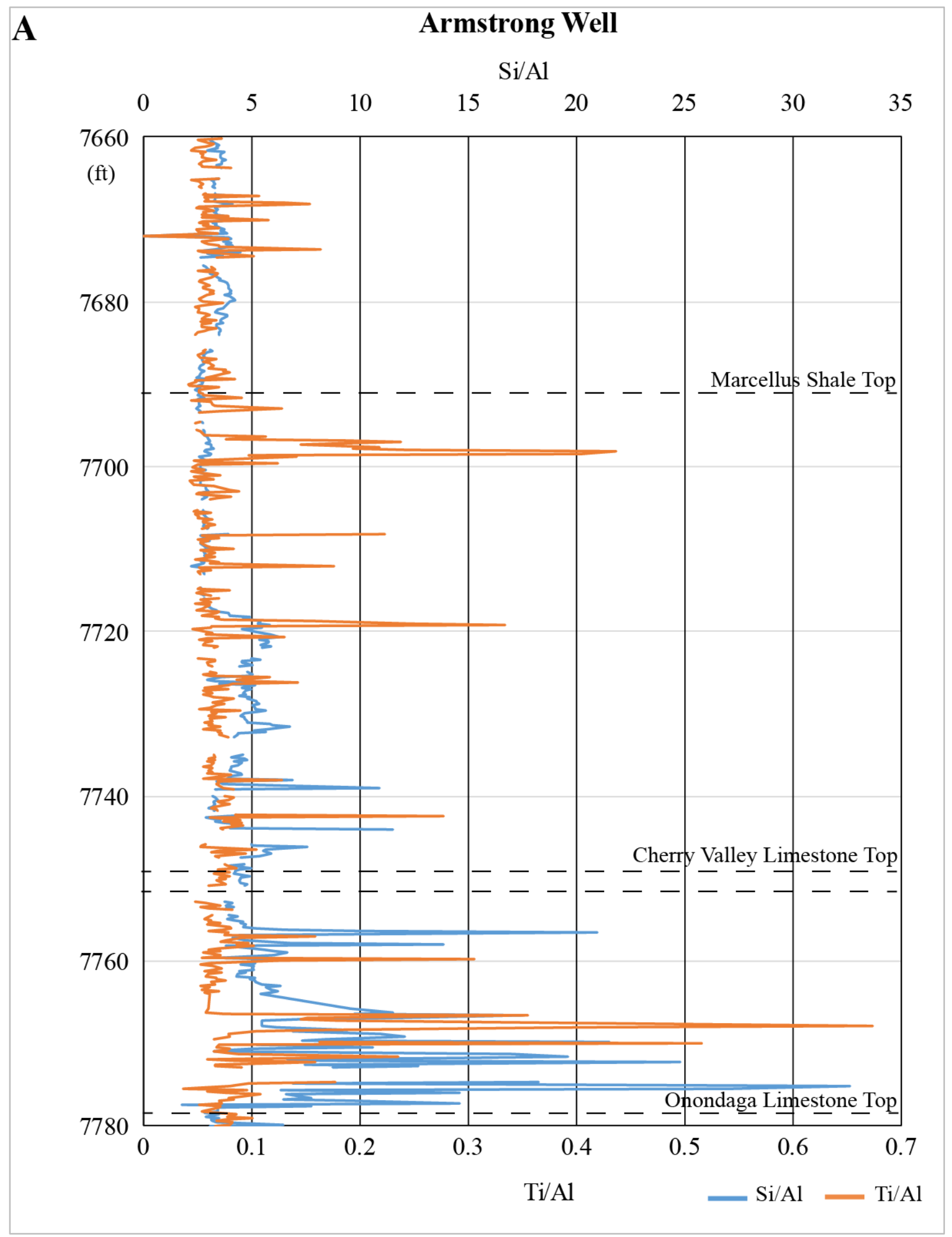

Figure 13a. Elemental ratios of $\mathrm{Si} / \mathrm{Al}$ and $\mathrm{Ti} / \mathrm{Al}$ from the handheld XRF on the Armstrong \#1 well. 
B

CSA Well

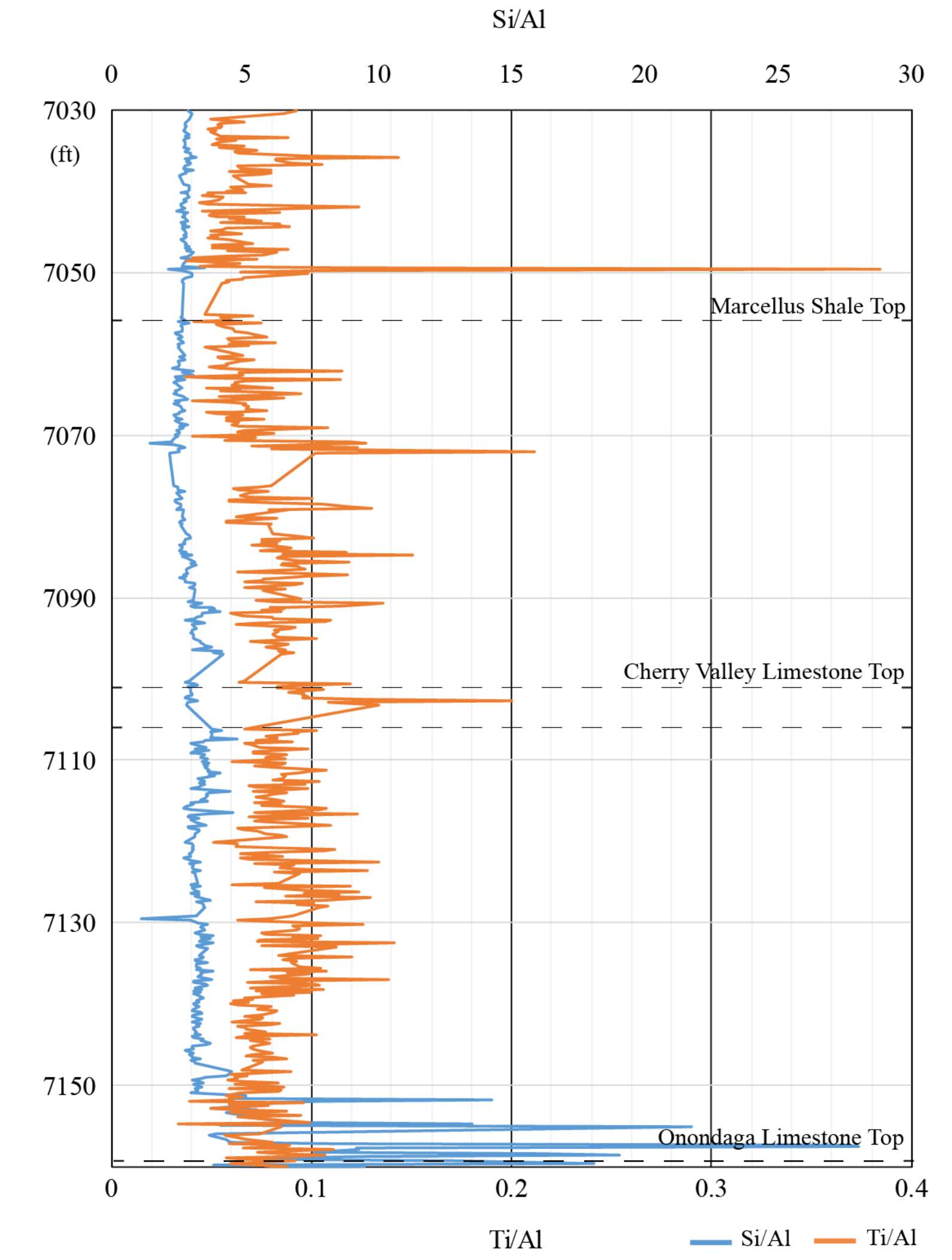

Figure 13b. Elemental ratios of $\mathrm{Si} / \mathrm{Al}$ and $\mathrm{Ti} / \mathrm{Al}$ from the handheld XRF on the CSA well. 


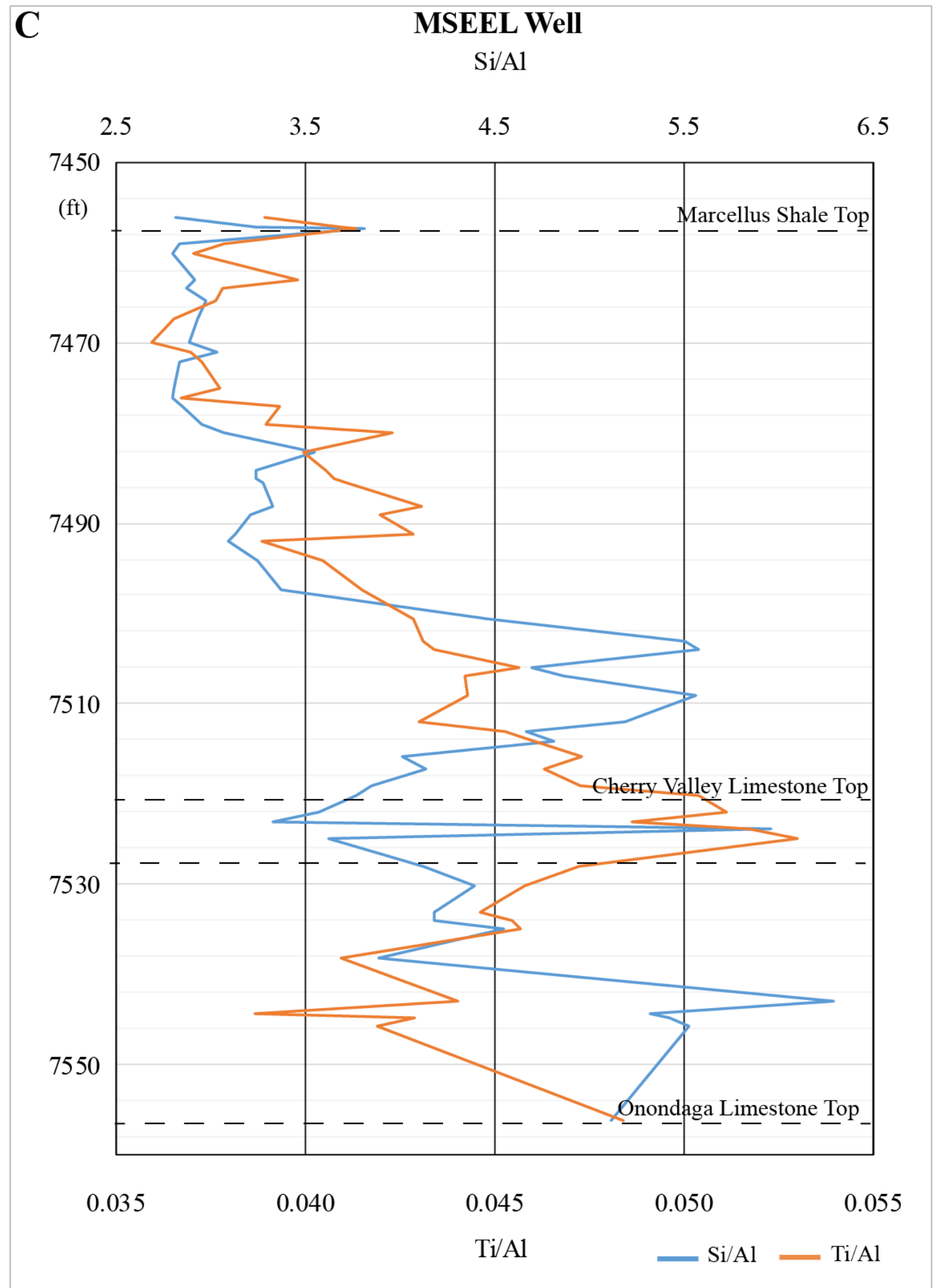

Figure 13c. Elemental ratios of $\mathrm{Si} / \mathrm{Al}$ and Ti/Al from the handheld XRF on the MSEEL well from Hupp (2017). 


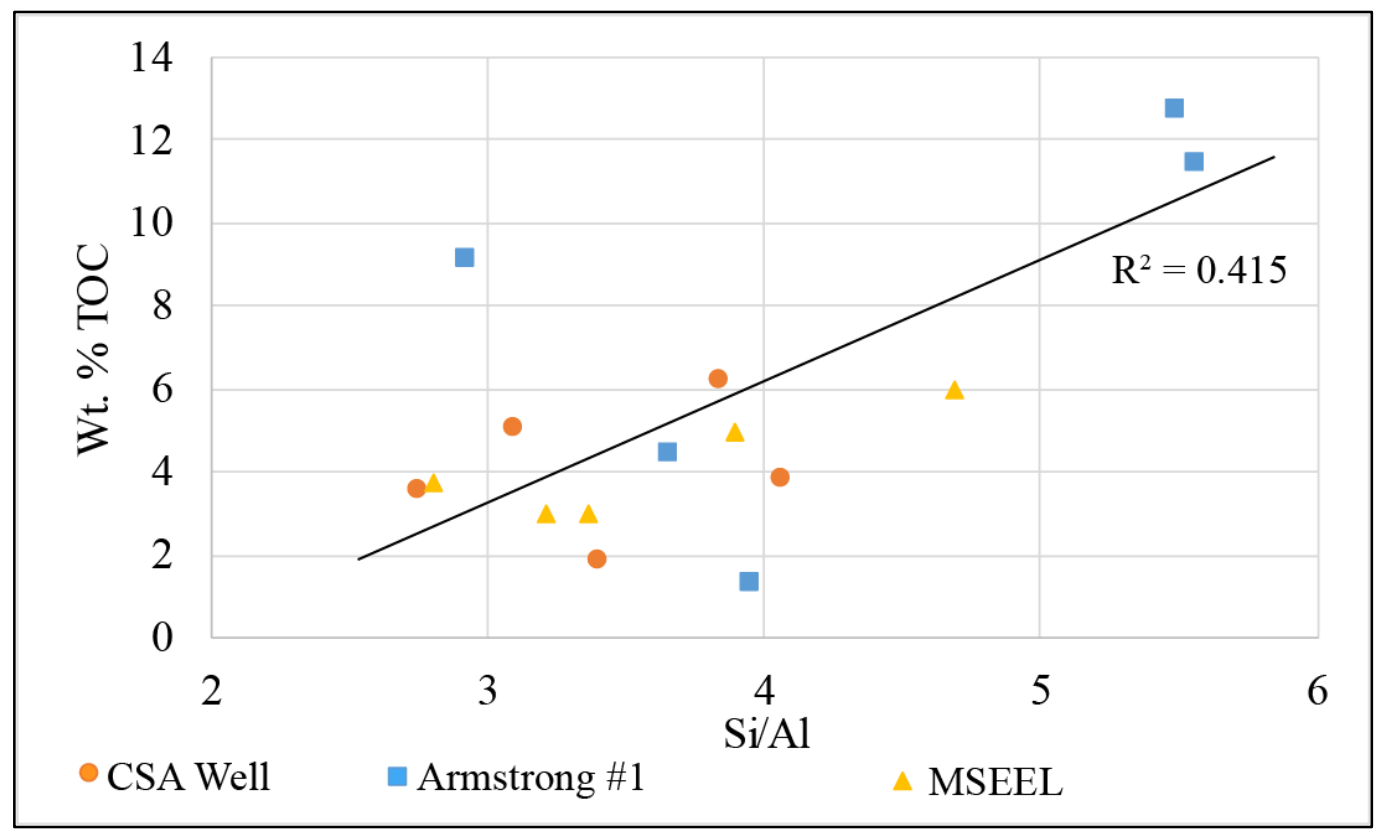

Figure 14. Cross plot between Wt. \% TOC and Si/Al for the CSA, Armstrong \#1, and MSEEL wells. TOC is high when $\mathrm{Si} / \mathrm{Al}$ is also high.

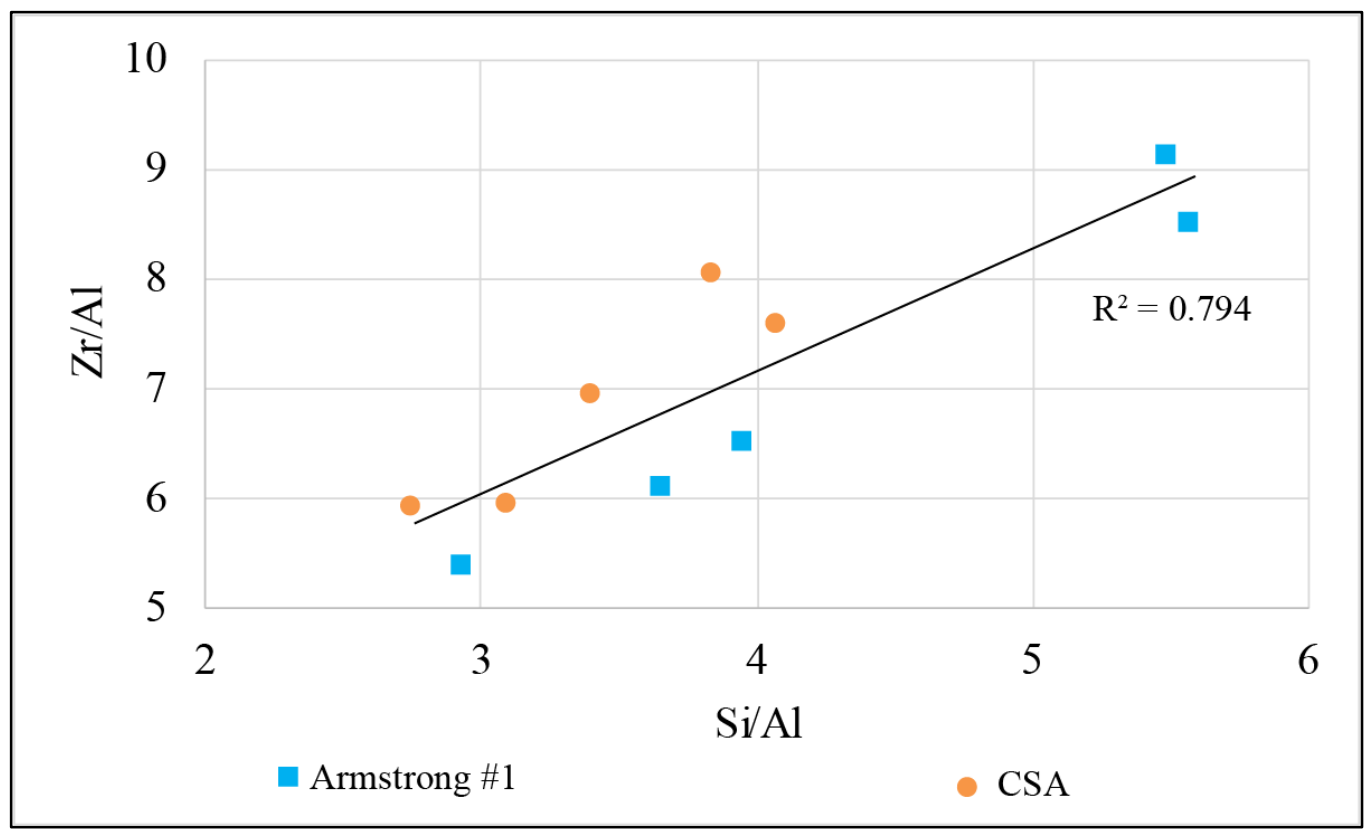

Figure 15. Zr and Si in the Armstrong \#1 and CSA wells are normalized to Al to show if biogenic Si is present. Due to the correlation, $\mathrm{Zr}$ and Si are influenced by the same sink mechanism. 
Table 6. Source classification interpretation for the sediments that make up the Armstrong \#1 and CSA wells using the cumulative data from Figures 5-9.

\begin{tabular}{|c|c|}
\hline Samples & Source Classification \\
\hline A-7660 & intermediate igneous \\
\hline A-7670 & recycled sedimentary \\
\hline A-7705 & felsic igneous \\
\hline A-7730 & recycled sedimentary \\
\hline A-7760 & intermediate igneous \\
\hline C-7032 & intermediate igneous \\
\hline C-7060 & intermediate igneous \\
\hline C-7075 & felsic igneous \\
\hline C-7110 & recycled sedimentary \\
\hline C-7144 & recycled sedimentary \\
\hline
\end{tabular}

\subsubsection{Sm-Nd Isotopic Composition: $\tau_{\mathrm{DM}}$ and $\varepsilon \mathrm{Nd}$}

Within the Armstrong \#1 and CSA wells, $\tau_{\mathrm{DM}}$ ranges from 1.62 to $1.91 \mathrm{Ga}$ and does not trend with depth. These $\tau_{\mathrm{DM}}$ ages are older than $\tau_{\mathrm{DM}}$ determined for Acadian Arc and younger than $\tau_{\mathrm{DM}}$ determined for the Superior Craton, but overlap with the other possible sources. The $\varepsilon_{\mathrm{Nd}}$ values range from -9.56 to -12.07 within the study wells, and becomes more negative upsection. These negative $\varepsilon_{\mathrm{Nd}}$ values are typical for chemically evolved upper crustal rocks (McLennan et al., 1993). The $\varepsilon_{\text {Nd }}$ values for the Armstrong \#1 and CSA wells overlap with all potential source areas except the Acadian Arc and Superior Craton.

\subsubsection{XRD Mineralogy}

XRD mineralogy within the Armstrong \#1, CSA, and MSEEL wells reveals that no major concentrations mafic minerals are present in XRD mineralogy results for the Armstrong \#1, CSA, or MSEEL wells. Quartz is the dominant mineral phase at base of the Marcellus Shale in all three wells. Clay mineral concentrations increase in relative abundance upsection compared to other phases (Fig. 16). Chlorite concentrations become more abundant in the Mahantango Formation in all wells. The base of the Union Springs Member does not contain any chlorite in 
Armstrong \#1 samples, whereas the CSA well Union Springs Member does contain a small percentage (<10\%). The lower Oatka Creek Member in both the Armstrong \#1 and MSEEL wells contains no chlorite but increases to 5-10\% in the upper Oatka Creek Member, signifying a change in extrabasinal detritus.

\subsection{Comparison to Various Source Compositions}

\subsubsection{Major, Trace, \& REE Geochemistry Abundances}

Trace (Fig. 17-21) and REEs (Fig. 22-25) were used to compare the results of this study with the possible provenances of the sediment (McLennan et al., 1993).

Acadian Fold-Thrust Belt: Within the Grenville felsic orogenic rocks, such as the Blue Ridge and New Jersey Highlands (Volkert et al., 1999; Tollo et al., 2004), concentrations of Ti, Co, and $\mathrm{Pb}$ (Fig. 17), as well as $\mathrm{REE}$ and La/Lu (Table 5) are similar to that of the Armstrong \#1 and CSA wells. Other comparisons in Table 5 do not form as strong of a relationship.

Within Taconic foreland strata (Bock et al., 1998), concentrations such as Sc and Cr (Fig. 18), as well as $\Sigma$ REE, Eu/Eu*, Ti/Zr, and La/Yb (Table 5) are similar to that of the Armstrong \#1 and CSA wells. Other comparisons in Table 5 do not form as strong of a relationship.

Acadian Arc: Within the Acadian Arc (D’Hulst et al., 2008), concentrations of Cr, Zr, and Hf (Fig. 19), as well as Zr/Sc (Table 5) are similar that of the Armstrong \#1 and CSA wells. However, all other comparisons in Table 5 do not form as strong of a relationship. This source was the least similar of all possibilities.

Superior Craton: Within the Superior Craton (Taylor et al., 1986; McLennan, 2001), concentrations such as Sc, Co, Pb, and Th (Fig. 20), as well as $\Sigma$ REE (Table 5) are similar to that of the Armstrong \#1 and CSA wells. Other comparisons in Table 5 do not form as strong of a relationship. 
A

Armstrong Mineralogy

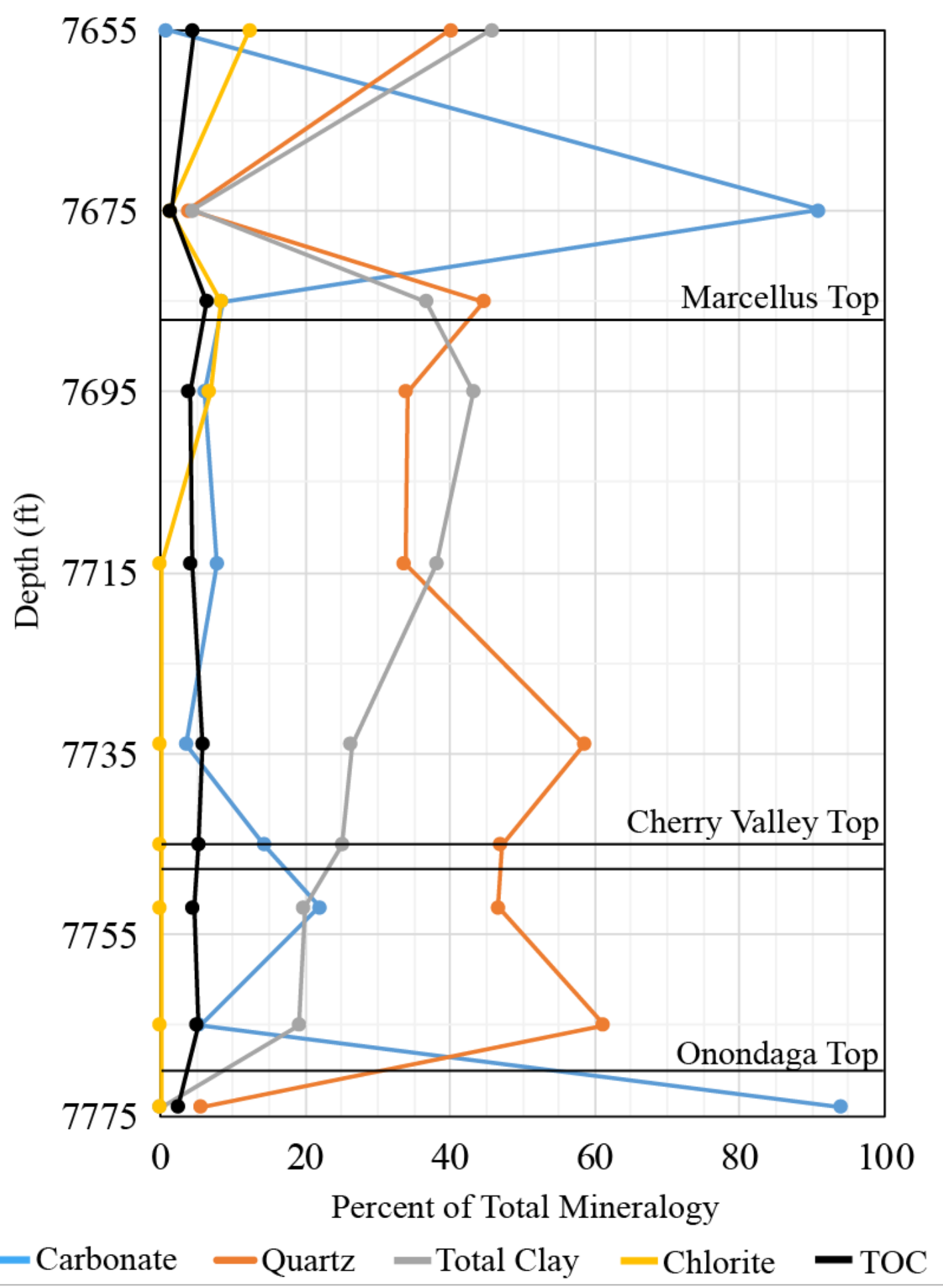

Figure 16a. XRD mineralogy of the Armstrong \#1, MSEEL, and CSA wells. Data from the Armstrong \#1 well collected by Core Laboratories. Chlorite is included in total clay. Carbonate includes calcite and dolomite. 


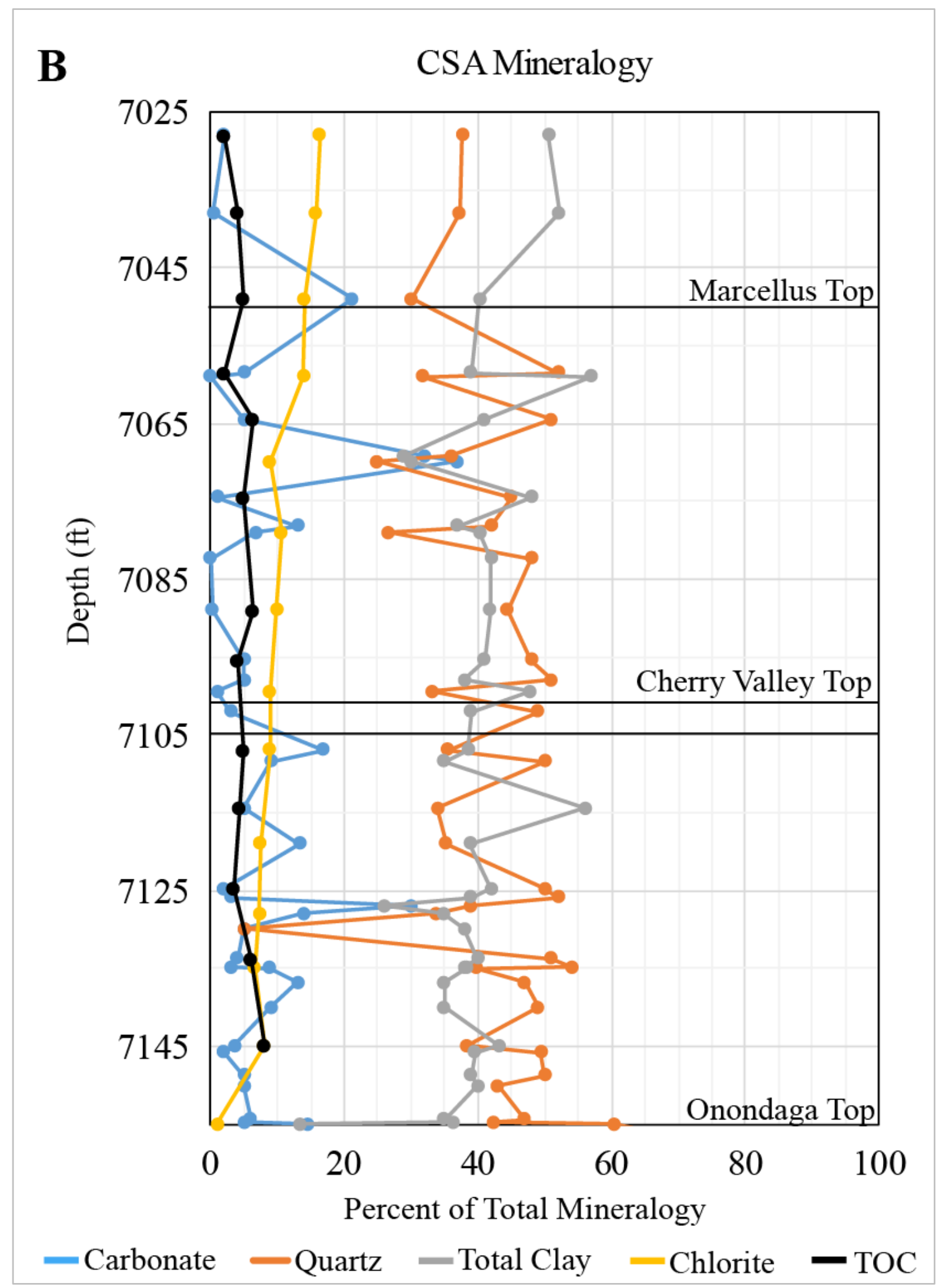

Figure 16b. XRD mineralogy of the CSA well. Data from the CSA well collected by Core Laboratories. Chlorite is included in total clay. Carbonate includes calcite and dolomite. 


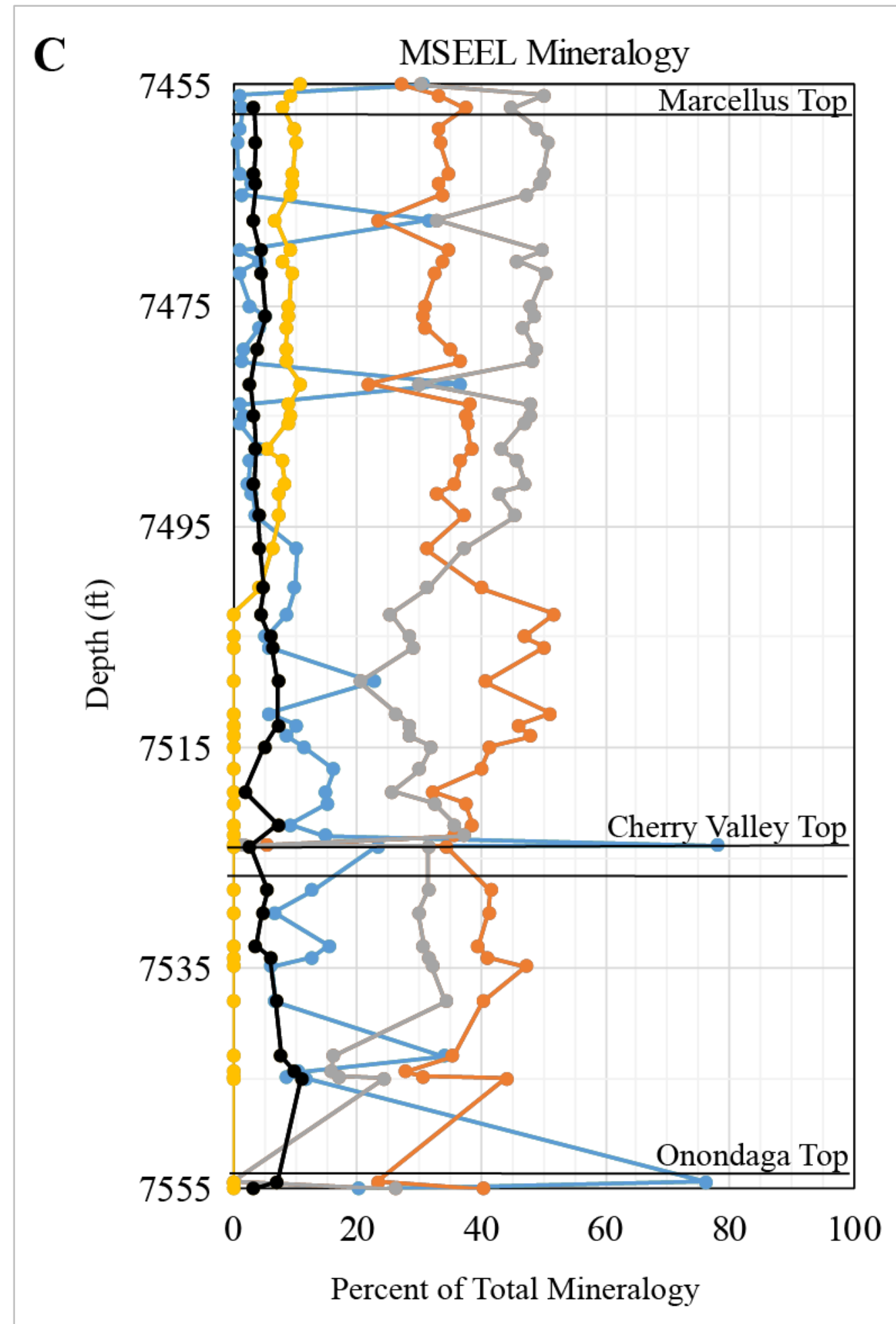

- Carbonate - Quartz - Total Clay - Chlorite - TOC

Figure 16c. XRD mineralogy of the MSEEL well. Data from the MSEEL well collected by Hupp (2017). Chlorite is included in total clay. Carbonate includes calcite and dolomite. 
Southern Canadian Grenville Province: Within the southern Canadian Grenville Province, specifically the accreted terranes of Algonquia and Barillia (Currie and Breemen, 1996; Prevec, 2004), concentrations such as Ti and Co (Fig. 21), as well as La/Lu, Eu/Eu*, $\mathrm{Cr} / \mathrm{Ni}, \mathrm{La} / \mathrm{Yb}$, and $\mathrm{Zr} / \mathrm{Sc}$ (Table 5) are similar to that of the Armstrong \#1 and CSA wells. Other comparisons in Table 5 do not form as strong of a relationship.

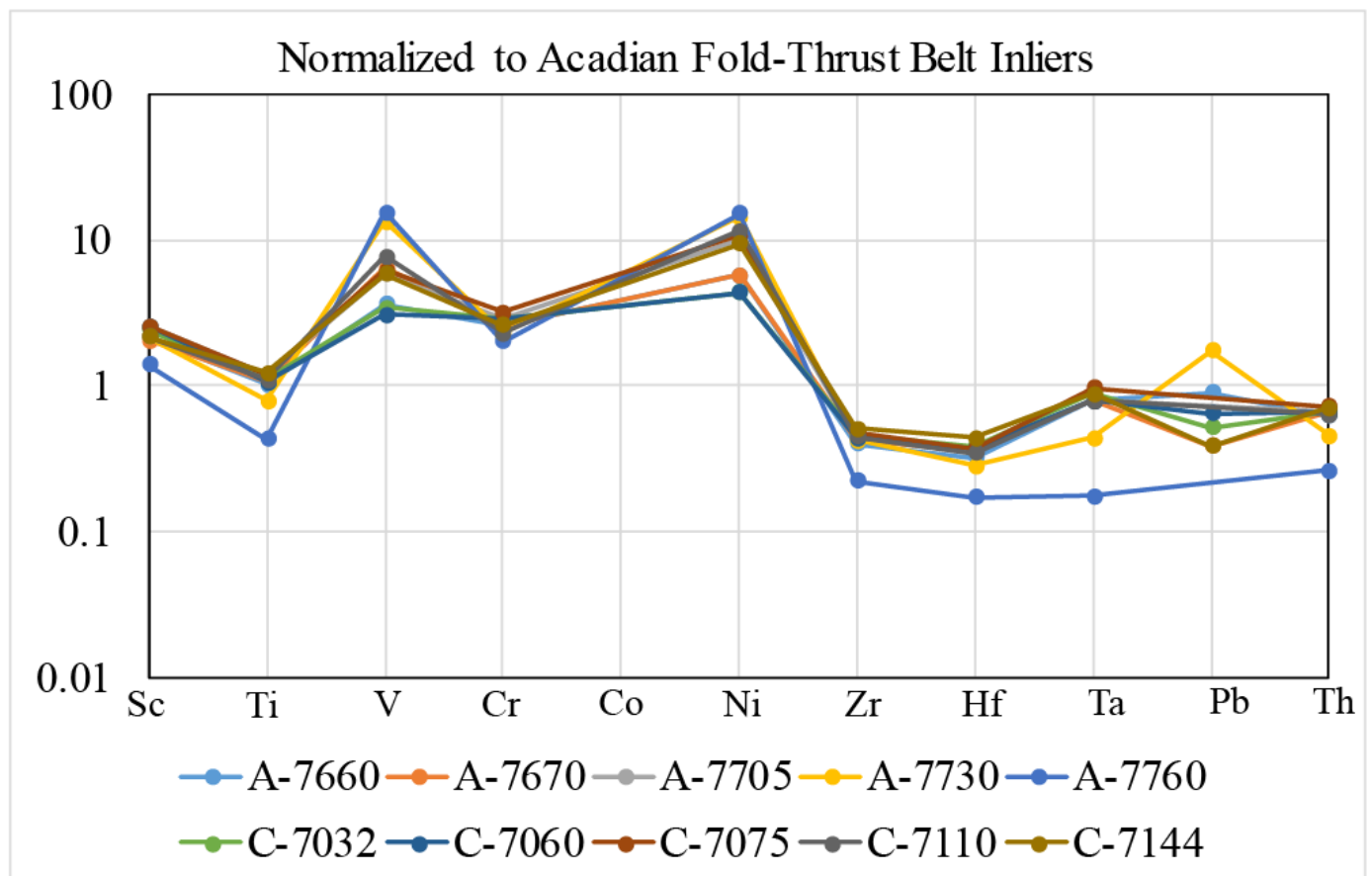

Figure 17. Major and trace element concentrations of the Armstrong \#1 (A) and CSA (C) wells normalized to average trace element concentrations of the grantitic Acadian Fold-Thrust Belt Inliers (Tollo et al., 2004). 


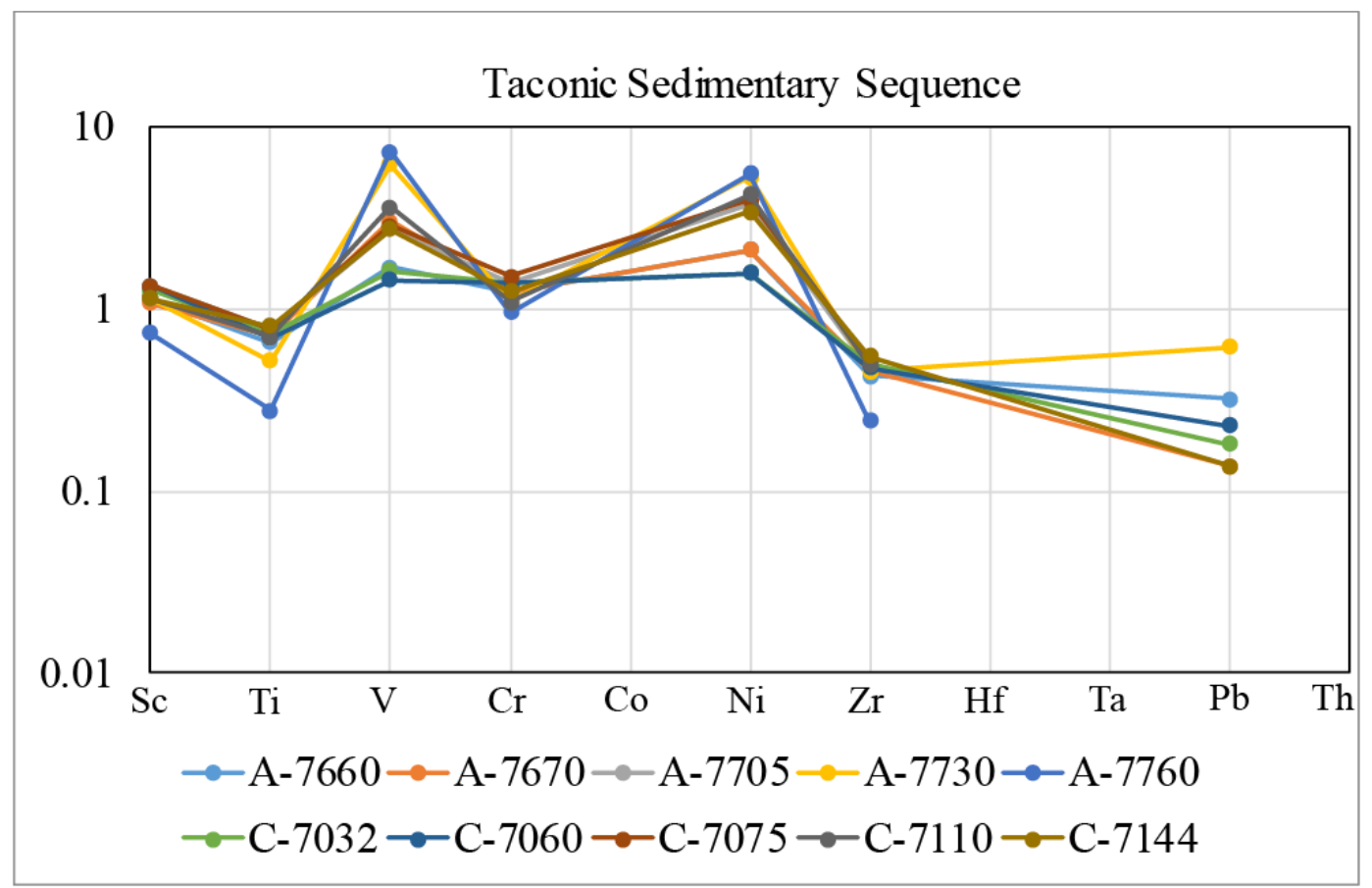

Figure 18. Major and trace element concentrations of the Armstrong \#1 (A) and CSA (C) wells normalized to average trace element concentrations of the Taconic Sedimentary Sequence (sedimentary fraction of Acadian Fold-Thrust Belt; Bock et al., 1998)

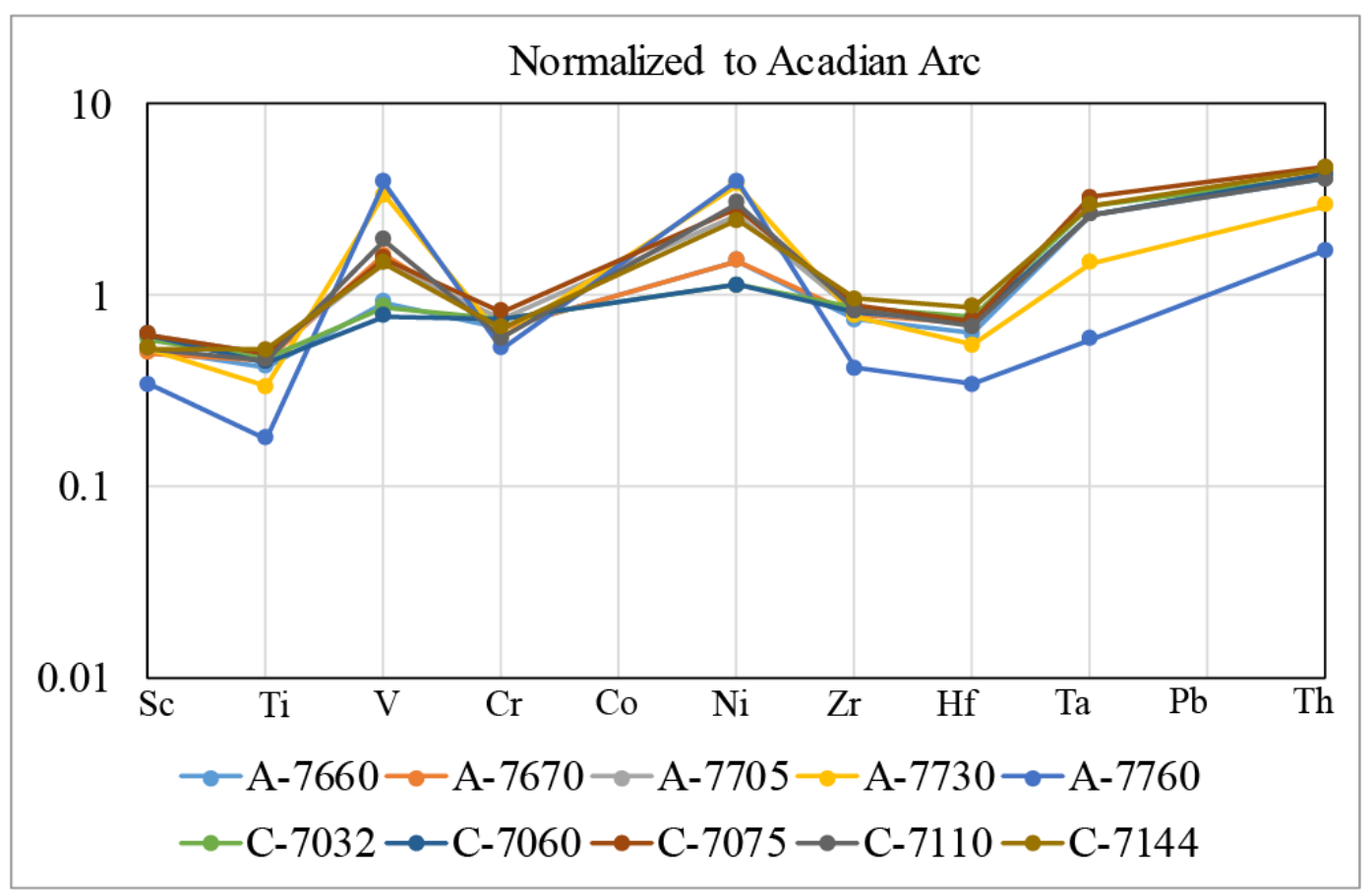

Figure 19. Major and trace element concentrations of the Armstrong \#1 (A) and CSA (C) wells normalized to average trace element concentrations of the Acadian Arc (D’Hulst et al., 2008). 


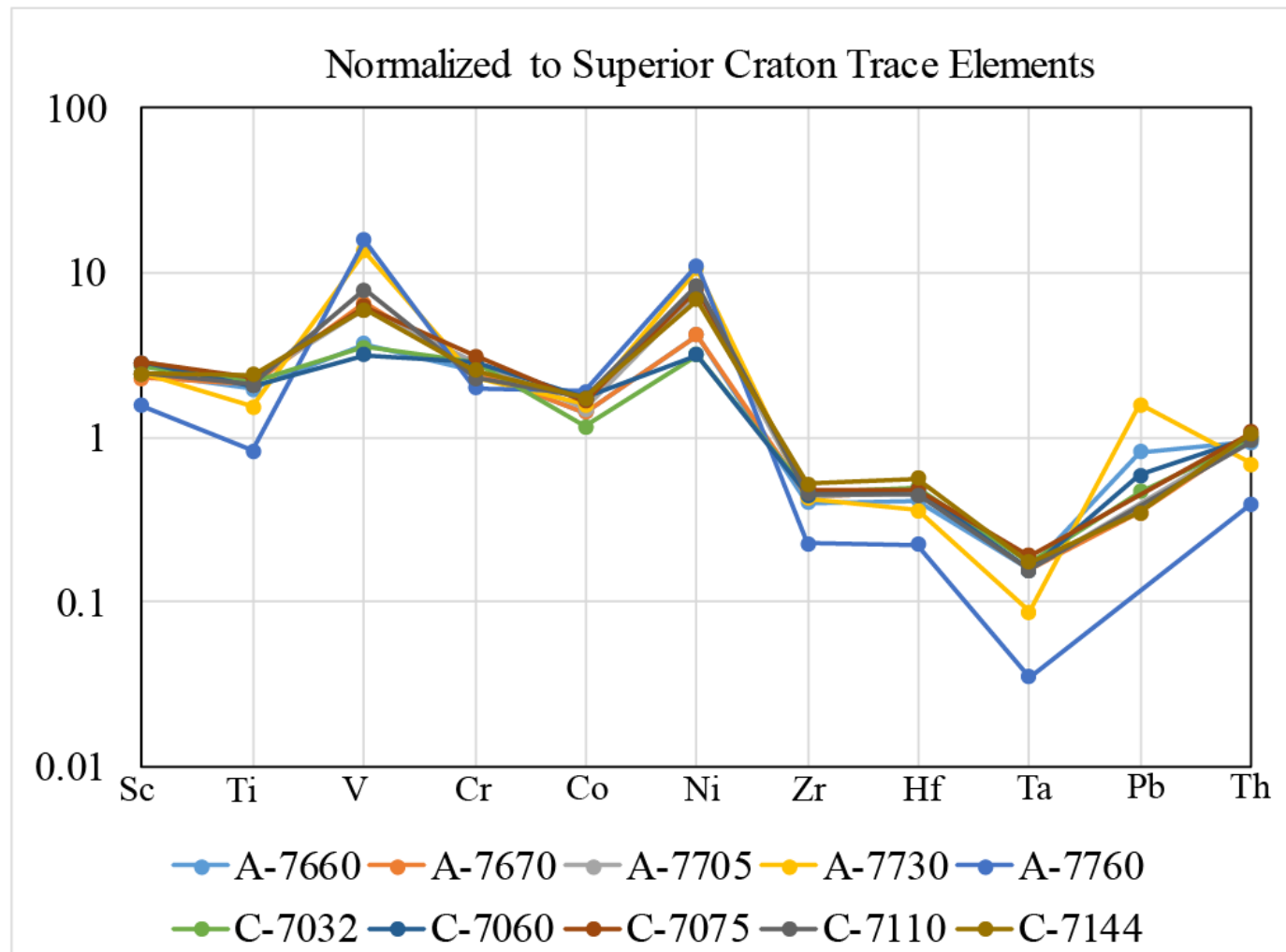

Figure 20. Major and trace element concentrations of the Armstrong \#1 (A) and CSA (C) wells normalized to average trace element concentrations of the Superior Craton (McLennan, 2001).

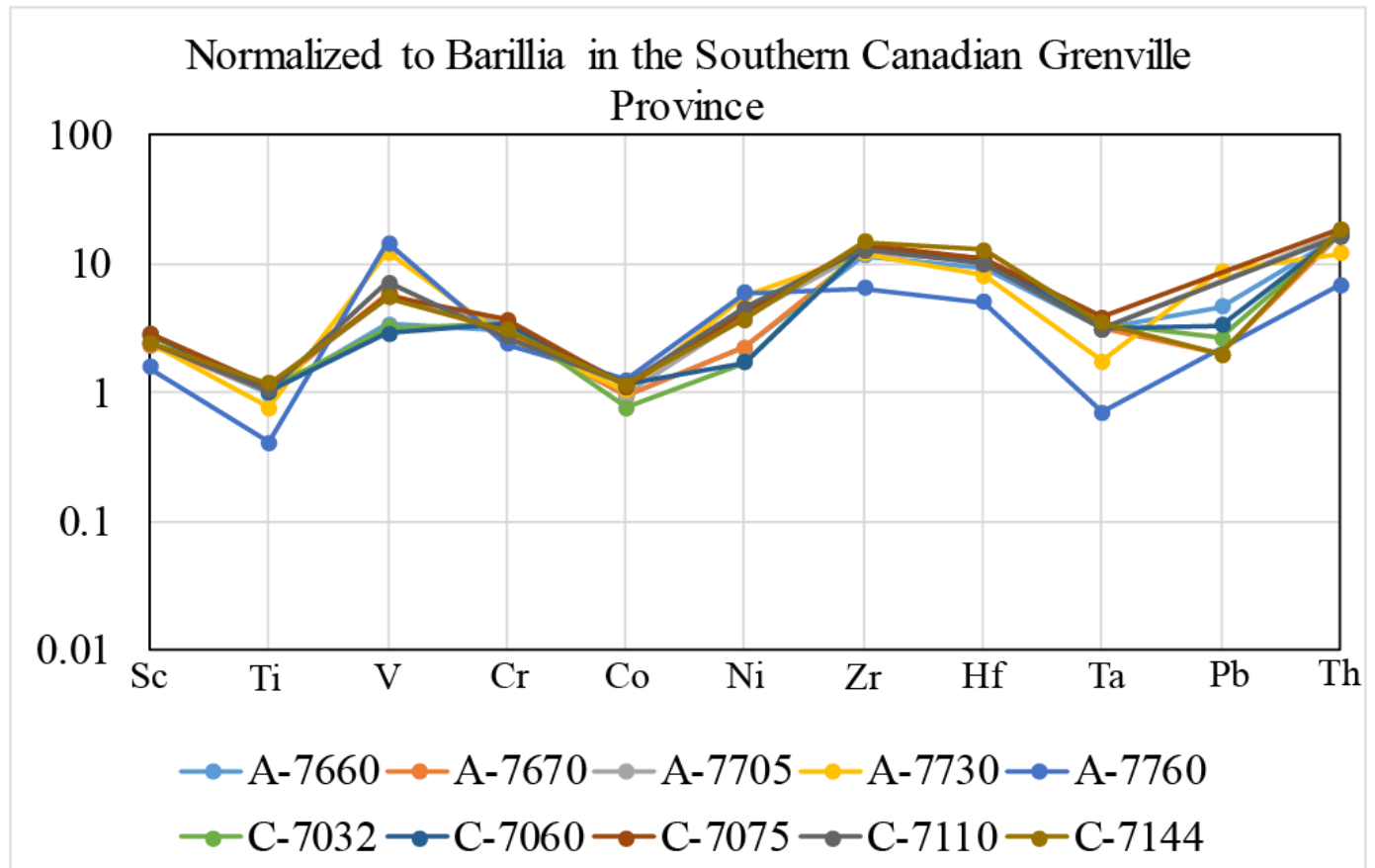

Figure 21. Major and trace element concentrations of the Armstrong \#1 (A) and CSA (C) wells normalized to average trace element concentrations of Barillia (Prevec, 2004). 


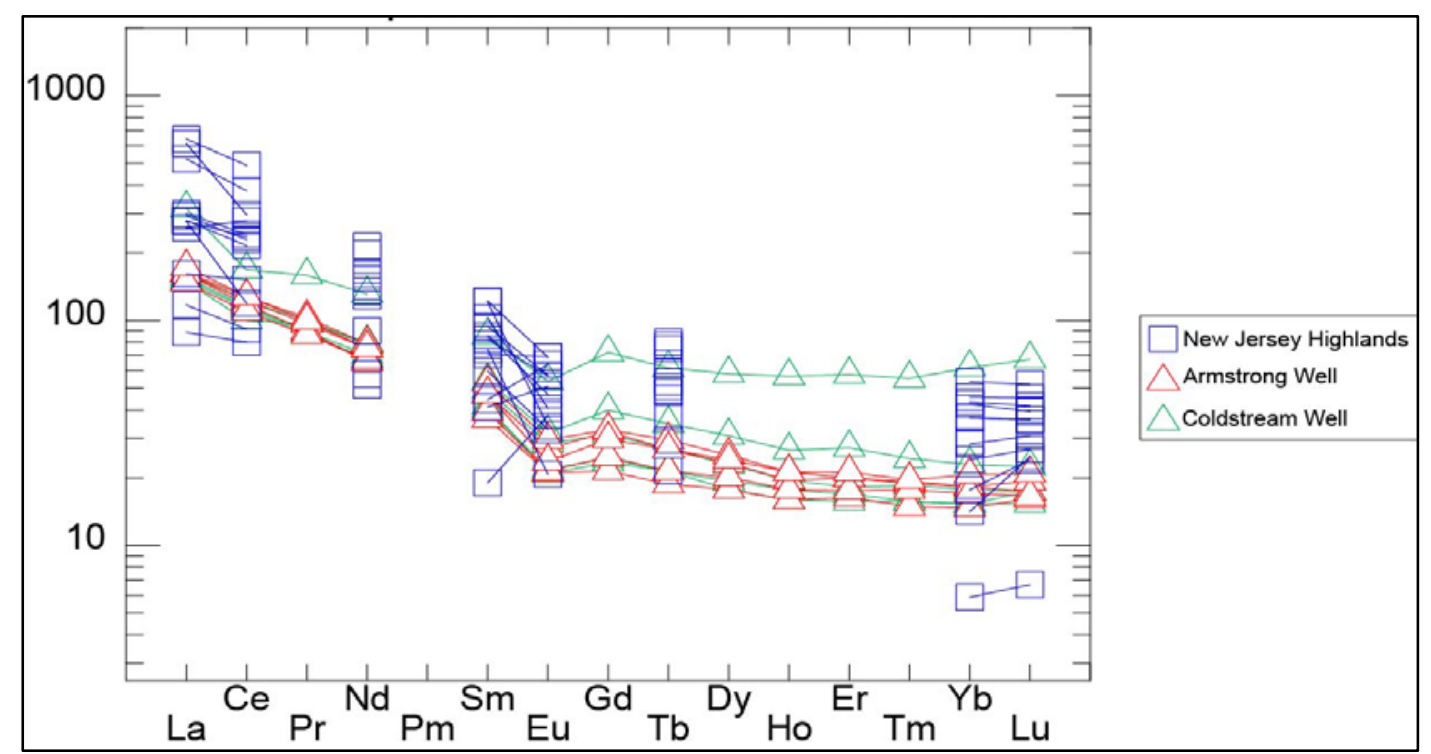

Figure 22. REE concentrations normalized to chondrite. Comparison is made between the Armstrong \#1 and CSA wells and the New Jersey Highlands (NJH) compositions (Volkert et al., 2000). La/Lu average from the Armstrong \#1 and CSA wells is 79 and the NJH La/Lu is 80 . $\mathrm{Eu} / \mathrm{Eu}^{*}$ average from the Armstrong \#1 and CSA wells is 0.23 and the $\mathrm{NJH} \mathrm{Eu/Eu*} \mathrm{is} 0.47$.

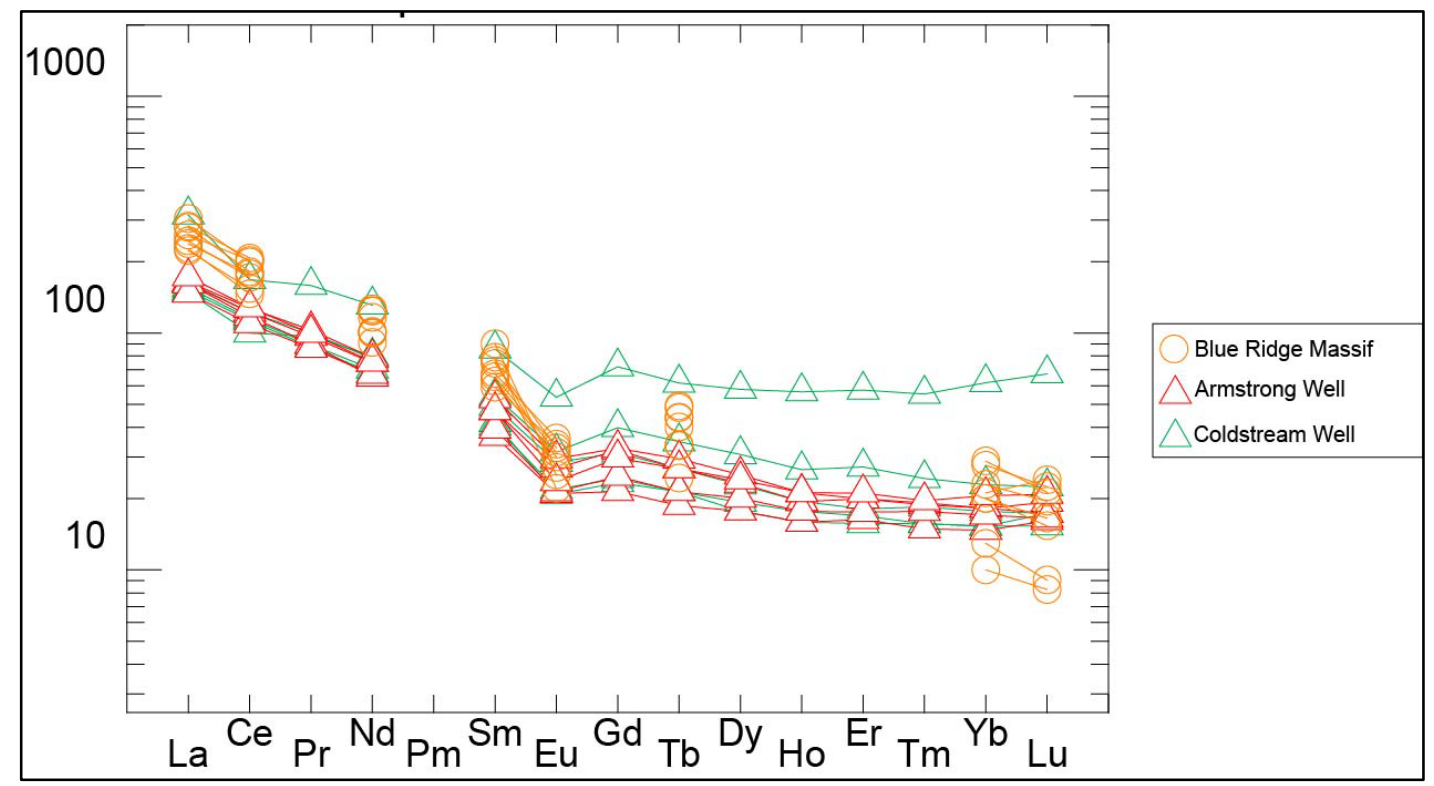

Figure 23. REE concentrations normalized to chondrite. Comparison is made between the Armstrong \#1 and CSA wells and the Blue Ridge Massif (BRM) compositions (Tollo et al., 2004). La/Lu average from the Armstrong \#1 and CSA wells is 79 and the BRM La/Lu is 139 . $\mathrm{Eu} / \mathrm{Eu}^{*}$ average from the Armstrong \#1 and CSA wells is 0.23 and the $\mathrm{BRM} \mathrm{Eu/Eu*} \mathrm{is} \mathrm{0.33.}$ 


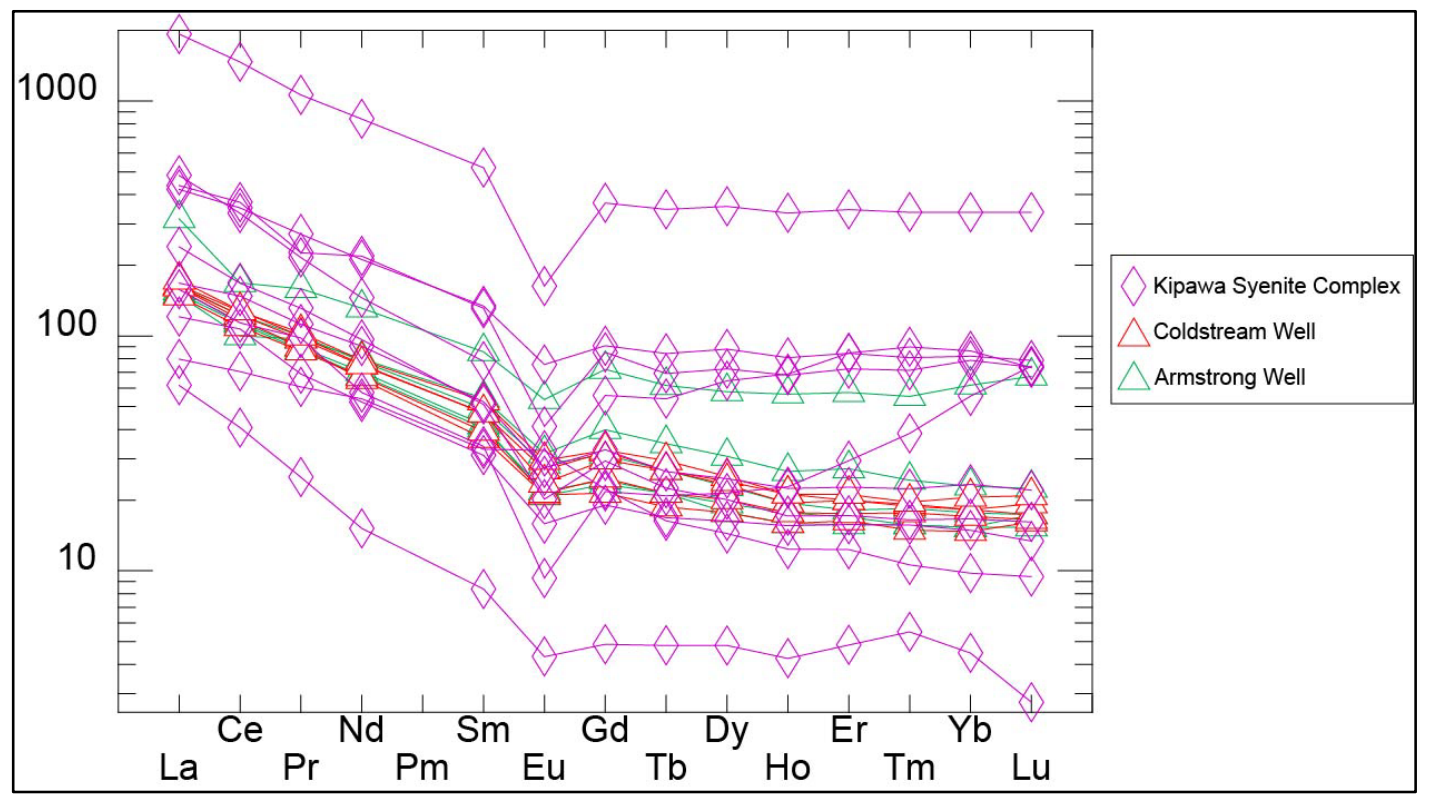

Figure 24. REE concentrations normalized to chondrite. Comparison is made between the Armstrong \#1 and CSA wells and Algonquia, specifically the Kipawa Syenite Complex (KSC), compositions (Currie and Breemen, 1996). La/Lu average from the Armstrong \#1 and CSA wells is 79 and the $\mathrm{KSC} \mathrm{La/Lu}$ is 82 . Eu/Eu* average from the Armstrong \#1 and CSA wells is 0.23 and the $\mathrm{KSC} \mathrm{Eu/Eu*} \mathrm{is} 0.19$.

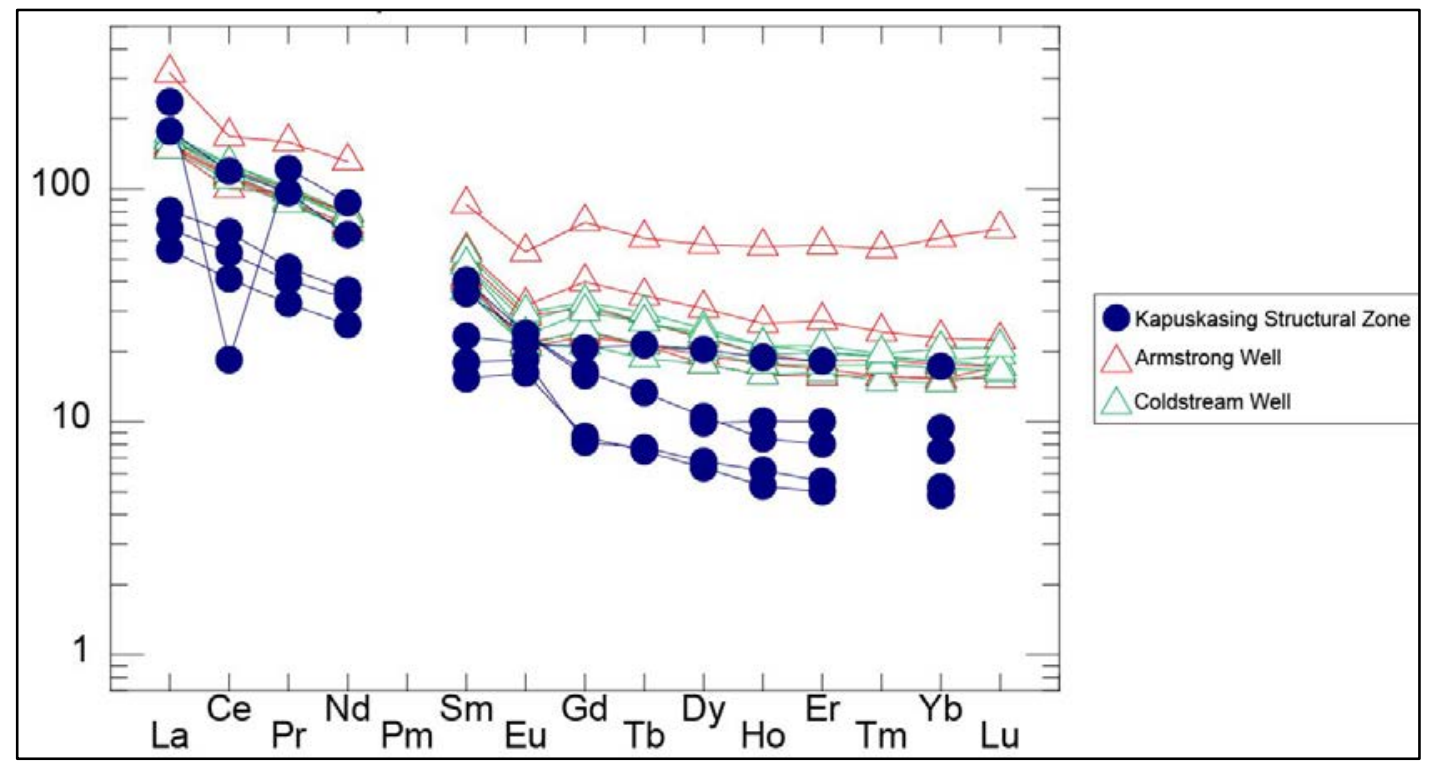

Figure 25. REE concentrations normalized to chondrite. Comparison is made between the Armstrong \#1 and Coldstream wells and Superior Craton, specifically the Kapuskasing Structural Zone (KSZ) compositions (Taylor et al., 1986). La/Lu average from the Armstrong \#1 and CSA wells is 79 and the KSZ La/Lu is 23. Eu/Eu* average from the Armstrong \#1 and CSA wells is 0.23 and the Kapuskasing Structural Zone Eu/Eu* is 0.37. 


\subsubsection{Signatures from Sm-Nd Radiogenic Isotopes}

The $\tau_{\mathrm{DM}}$ of any of the potential sources do not overlap the Armstrong \#1 and CSA wells' $\tau_{\mathrm{DM}}(1.62$ to $1.91 \mathrm{Ga})$ results seen (Table 5$)$. This necessitates a mixing of two or more of the potential sources to get the $\tau_{\mathrm{DM}}$ results observed in the Armstrong \#1 and CSA wells. At least one source with older $\tau_{\mathrm{DM}}$, such as the southern Canadian Grenville Province (up to $1.9 \mathrm{Ga}$ ), Superior Craton (>2.7 Ga), or Taconic foreland strata (up to $2.2 \mathrm{Ga}$ ), is essential to mix to create the results seen in the Armstrong \#1 and CSA wells.

The current $\varepsilon_{\mathrm{Nd}}$ of the Grenville Inliers and Taconic foreland strata mix overlap well with results seen in the Armstrong \#1 and CSA wells. Input from other sources such as the southern Canadian Grenville Province and Superior Craton are still possible, however the input needs to be lesser than that of the Grenville Inliers or Taconic foreland strata to keep the $\varepsilon_{\mathrm{Nd}}$ around -11 .

\subsection{Provenance Model}

\subsubsection{Sediment Source Area}

There is evidence to support that during deposition of the Hamilton Group, there was erosion from the Taconic foreland strata from the Acadian Fold-Thrust Belt with minor inputs from Superior and southern Canadian Grenville Province due to the older $\tau_{\mathrm{DM}}$ signatures and trace/REE compositions present in the Armstrong \#1 and CSA wells. However, during deposition of young $\tau_{\mathrm{DM}}$ rocks, the source of the sediments can be constrained to the Grenville Inliers within the Acadian Fold-Thrust Belt, with less input of the Taconic foreland strata. The younger $\tau_{\mathrm{DM}}$ is also seen by the shift to more intermediate igneous sources upsection in the Armstrong \#1 and CSA wells which may be the Acadian Arc contributing sediment. 


\subsubsection{Sediment Transport Pathway}

Erosion from older source material such as the southern Canadian Grenville Province and Superior Craton has been proposed for sediment supply for the Ordovician-aged Utica and Normanskill Formations, due to older $\boldsymbol{\tau}_{\text {DM }}$ signatures and more negative $\varepsilon_{\text {Nd }}$ values (Bock et al., 1998; Hurowitz and McLennan, 2005; Chakrabarti et al., 2007; Caesar et al., 2010). In order for the sediments to be eroded from the Canadian sources, there had to be uplift in this region. The Algonquin Arch was actively uplifted during the middle Paleozoic (Sanford et al., 1985). The uplift would allow for the Superior Craton and/or southern Canadian Grenville Province to be eroded. The Superior Craton has been exposed since 1.1 Ga (Queen et al., 1996; Canil, 2008) and the southern Canadian Grenville Province was exhumed around 1.0 Ga and has been exposed since then (Martignole and Reynolds, 1997). The sediments may have then traveled along river channels that are on basement structural lineaments that are preferentially oriented towards the Appalachian Basin (Fig. 26; Eyles et al., 1993) or along flanks of the Algonquin arch (Birchard et al., 2004). Erosional surfaces and sandy conglomeratic accumulations observed above the Onondaga equivalent in southern Ontario, Buffalo, New York, and north-central Ohio support this hypothesis (Hatfield et al., 1968; Armstrong, 2006; Brett et al., 2011). In Buffalo, New York the Union Springs and half of the Oatka Creek missing due to non-deposition (Brett et al., 2011 and Lash and Engelder, 2011). An argument can be made that the sediment was moving from the Superior Craton and/or southern Canadian Grenville Province into the Acadian Basin across this region.

Pinet (2016) posits a "fairway" developed due to extension in Silurian and Early Devonian in the northern Appalachian Basin. This “fairway” matches the Rome Trough orientation (Harper, 1989; Fig. 1). Sediment transport through “fairway” mixed sediment from 
various sources, causing the observed $\boldsymbol{\tau}_{\mathrm{DM}}$ and $\varepsilon_{\mathrm{Nd}}$ signatures of the Marcellus Shale (Fig. 27 and 28; Bock et al., 1998, Chakrabarti et al., 2007, Caesar et al., 2010, Phan et al., 2018, and Hupp and Weislogel, 2018). A study of Marcellus Sm-Nd by Caesar et al. (2010) was carried out near the Catskill Delta outside of this fairway, which could explain why its signatures were dominated by younger $\boldsymbol{\tau}_{\mathrm{DM}}$ ages and more immature $\varepsilon_{\mathrm{Nd}}$ signatures consistent with influx from mainly eroded Grenville rocks.

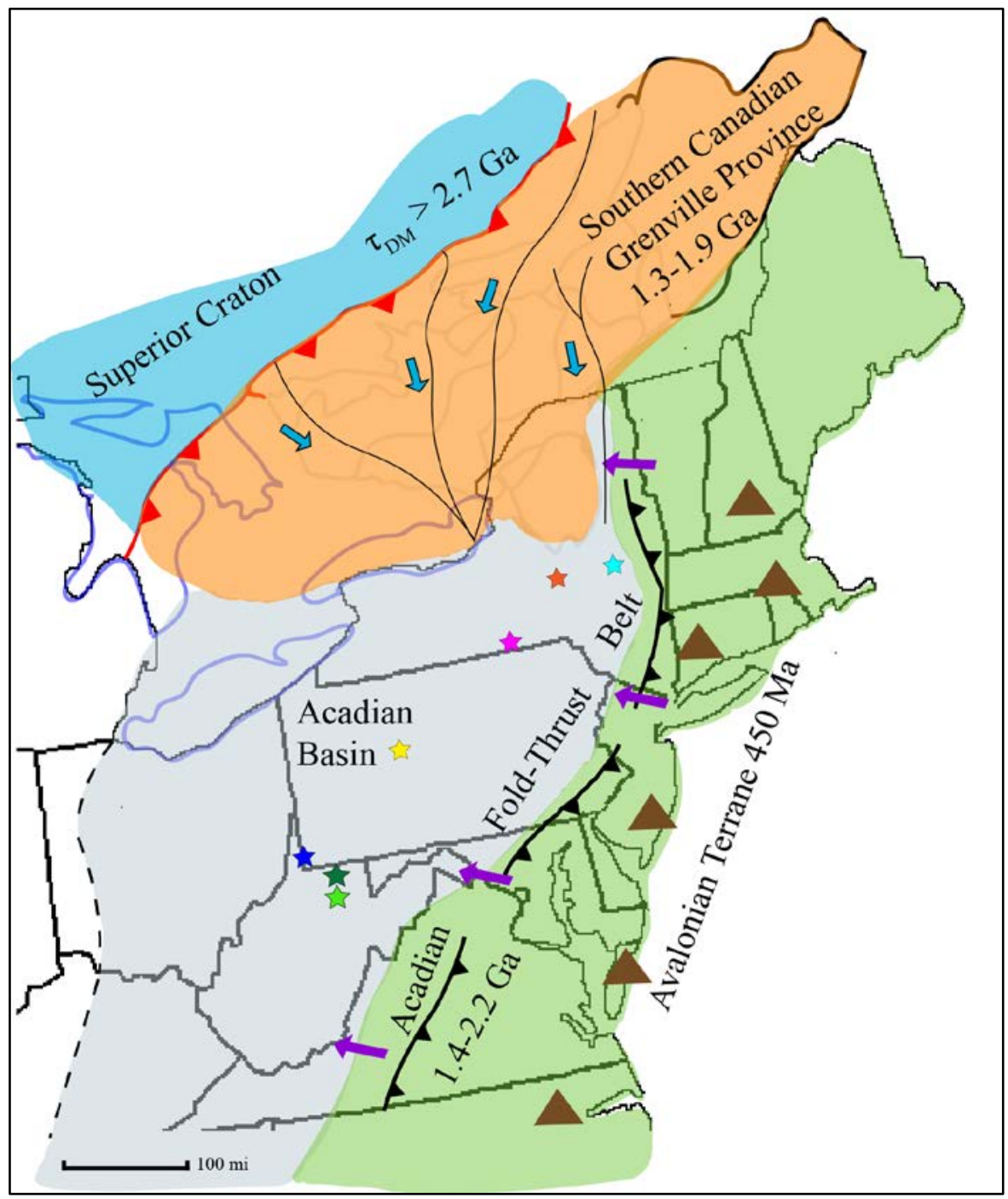

Figure 26. Map of the Middle Devonian Acadian Basin and generalized sediment sources. Blue and purple arrows display possible directions of sediment influx from the various sediment sources. Data combined from Patchett et al. (1999), Percival et al. (2006), and McLelland et al. (2010). 


\subsubsection{Temporal Provenance Evolution}

Overall, geochemical and petrographic evidence indicate that sources become more immature upsection (Table 4). No major concentrations mafic minerals are present in XRD mineralogy results for the Armstrong \#1, CSA, or MSEEL wells. Quartz is the dominant mineral phase at base of the Marcellus in all three wells. Clay mineral concentrations increase in relative abundance upsection compared to other phases (Fig. 16). Chlorite concentrations become more abundant in the Mahantango Formation, while the base of the Union Springs Member does not contain any chlorite. The petrographic results indicated that detrital quartz grains were subrounded in the Union Springs Member to sub-angular within the Mahantango Formation. Subrounded to rounded quartz grains are also noticed in detrital quartz grains of both the Onondaga Limestone equivalent and Union Springs Member in southern Ontario, western New York, and northern Ohio (Armstrong, 2006 and Brett et al., 2011). This may be evidence for sediment traveling from Superior Craton/Southern Canadian Grenville Province. Also, the change from sub-rounded to sub-angular grains and the increase in laminations with decreasing depth indicates that the source of the sediments became closer over time. This could be due to a change in sediment source or progradation of deltas, such as the Catskill, into the basin. 


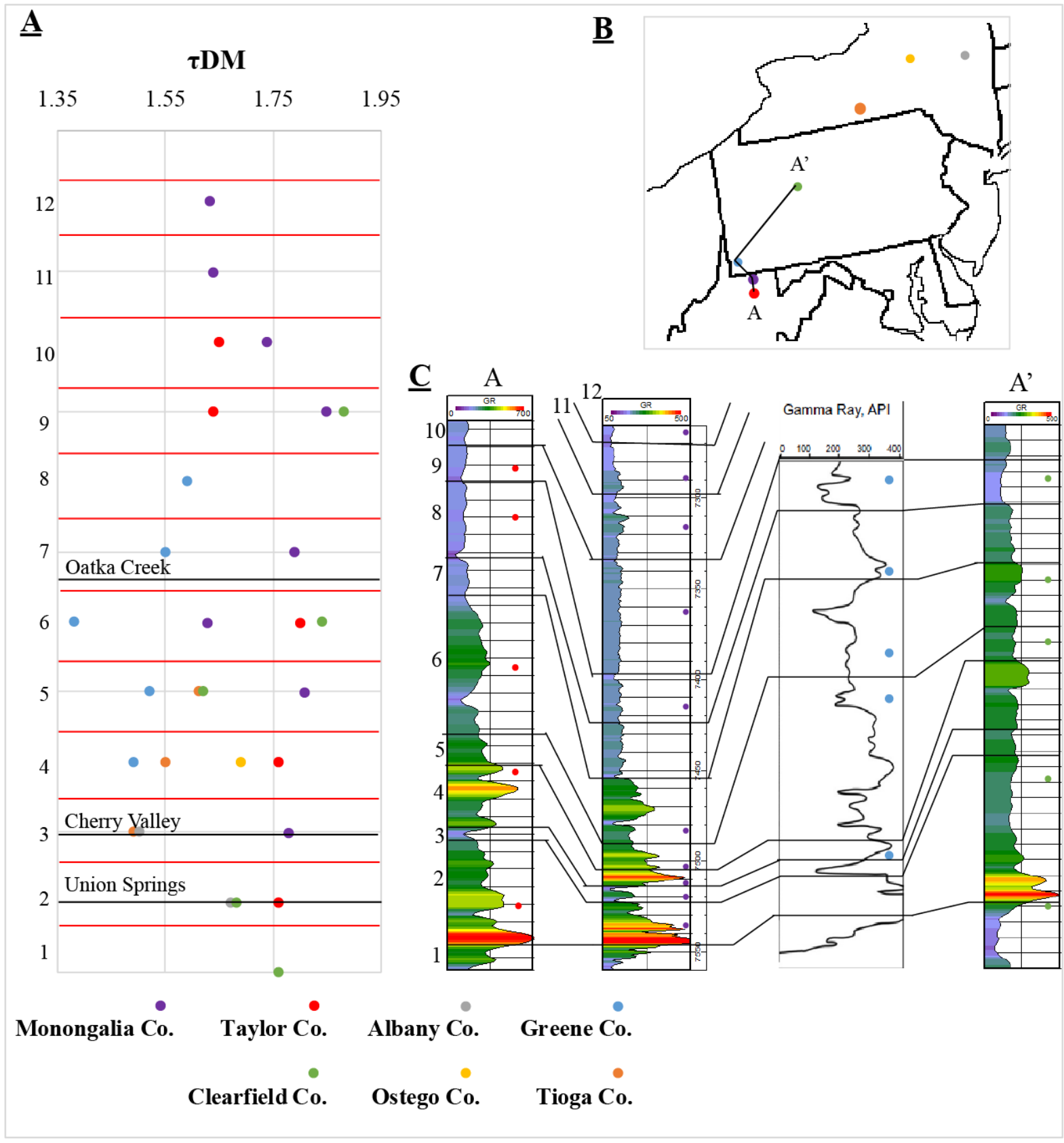

Figure 27. Collective provenance studies of $\boldsymbol{\tau}_{\mathrm{DM}}$ of the Hamilton Group using Sm-Nd isotopes. Monongalia County data from Hupp (2017), Albany and Ostego County from Caesar et al. (2010), Greene and Tioga County from Phan et al. (2018), and Taylor and Clearfield County data from this study. All data above the Oatka Creek is from the Mahantango Formation. (A) Lithostratigraphic horizons showing how $\boldsymbol{\tau}_{\mathrm{DM}}$ can vary in different areas of the basin. (B) Map showing the cross-section from A-A'. (C) Cross section using a Gamma Ray (GR) log from AA' showing the different horizons picked. 

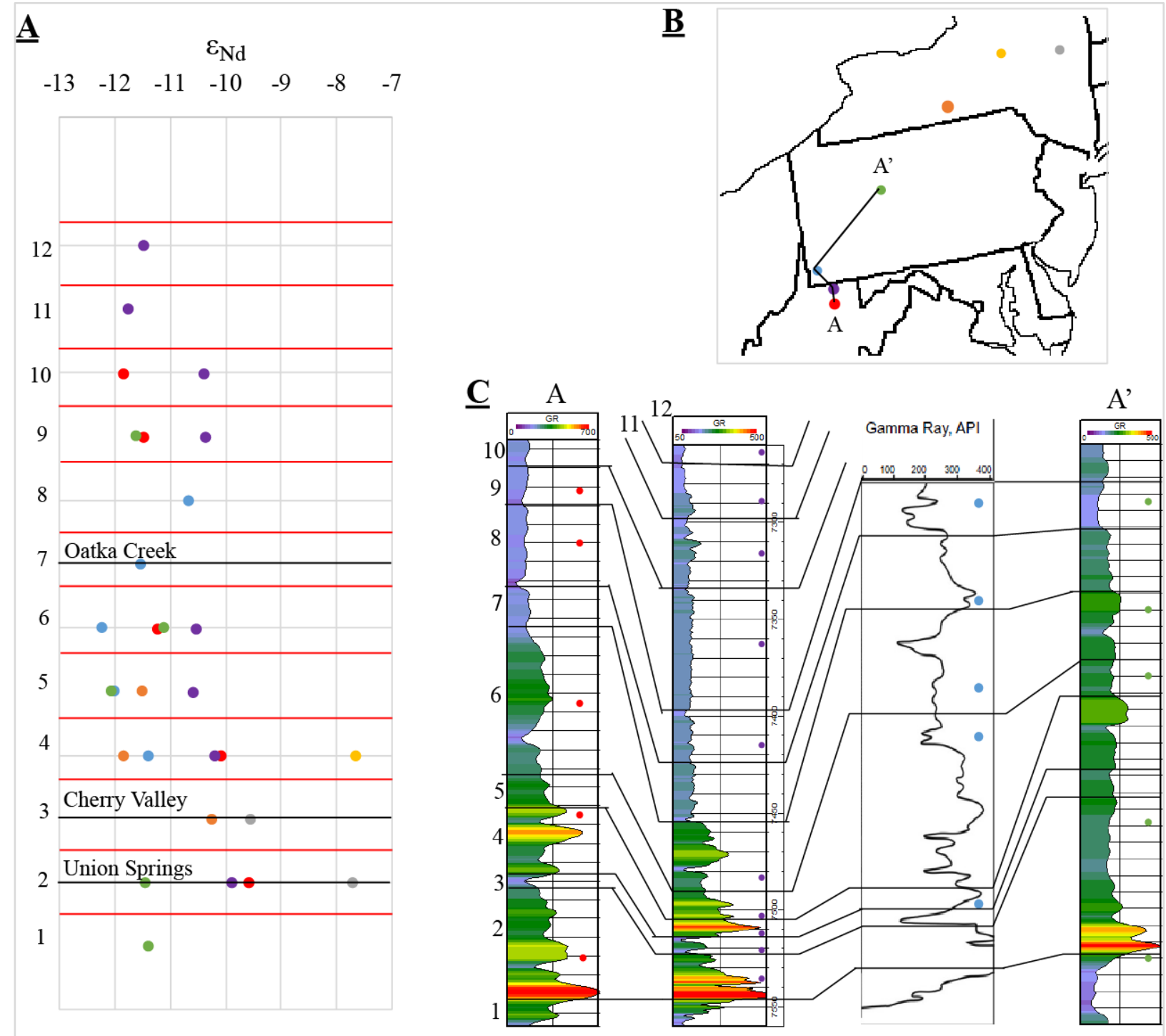

$\bullet \bullet$

Monongalia Co. Taylor Co. Albany Co. Greene Co.

\section{Clearfield Co. Ostego Co. Tioga Co.}

Figure 28. Collective provenance studies of $\varepsilon_{\mathrm{Nd}}$ of the of the Hamilton Group using Nd isotopes. Monongalia County data from Hupp (2017), Albany and Ostego County from Caesar et al. (2010), Greene and Tioga County from Phan et al. (2018), and Taylor and Clearfield County data from this study. All data above the Oatka Creek is from the Mahantango Formation. (A) Lithostratigraphic horizons showing how $\varepsilon_{\mathrm{Nd}}$ can vary in different areas of the basin. (B) Map showing the crosssection from A-A'. (C) Cross section using a Gamma Ray (GR) log from A-A' showing the different horizons picked. 


\subsection{Thermal Maturity from Laser Raman Spectroscopic Analysis}

Raman spectroscopic results confirmed the previous understanding about the thermal maturity differences amongst the three wells set by vitrinite reflectance data and thermal maturity mapping done by Repetski et al. (2008). This study mapped thermal maturity using vitrinite reflectance from approximately 425 well cuttings samples across the Appalachian basin, from the Cincinnati Arch to the Allegheny Structural Front. Repetski et al. (2008) has the CSA well as the most thermally mature in the basin with a $\mathrm{VR}_{0}$ at approximately $2 \%$ while the MSEEL and Armstrong \#1 wells are at approximately 1.6\%. The G- and D-band separations of the CSA well samples were greatest, converting to around $2.4 \% \mathrm{VR}_{0}$. The MSEEL well and the Armstrong \#1 well G- and D-band separations were less, converting to around $2 \% \mathrm{VR}_{0}$. Both previously measured by Core Laboratories, the CSA well had an averaged measured VRo of 2.72\% and the Armstrong \#1 well had an averaged measured VRo of 1.40\%. Although the conversion of G- and D-band separations to vitrinite reflectance was not exact, it still exemplifies thermal maturity and shows that the CSA well was the most mature, matching the outcomes seen in Repetski et al. (2008). 


\subsection{Relationship between Provenance and Controls on Organic-Matter Preservation}

A stratified water column allows for organic preservation because the bottom of the column will be anoxic (Sageman et al., 2003). The high molybdenum and uranium concentrations are evidence for anoxic to euxinic water (Appendix 1; Lash and Blood, 2014). The deeper water in fairway would have allowed for organic preservation. A warm, sunny climate enhances plankton productivity. Both of these conditions are existent today at the $30^{\circ}$ latitudes and are inferred in the past as well (Sageman et al., 2003). There is general positive correlation between TOC and $\boldsymbol{\tau}_{\mathrm{DM}} / \varepsilon N d$ (Fig. 29 and 30). This indicates that TOC $>6 \%$ is developed when sediment with $\boldsymbol{\tau}_{\mathrm{DM}}$ over $1.75 \mathrm{Ga}$ is being delivered to the basin; however, even when sediment with $\boldsymbol{\tau}_{\mathrm{DM}} \geq 1.75 \mathrm{Ga}$ is being delivered to the basin TOC may be $<6 \%$. This suggests that one condition for TOC $>6 \%$ was influx of $\boldsymbol{\tau}_{\mathrm{DM}} \geq 1.75$ Ga sediment, but that other conditions, such as perhaps water stratification, were also required for high TOC deposits to form and be preserved. 


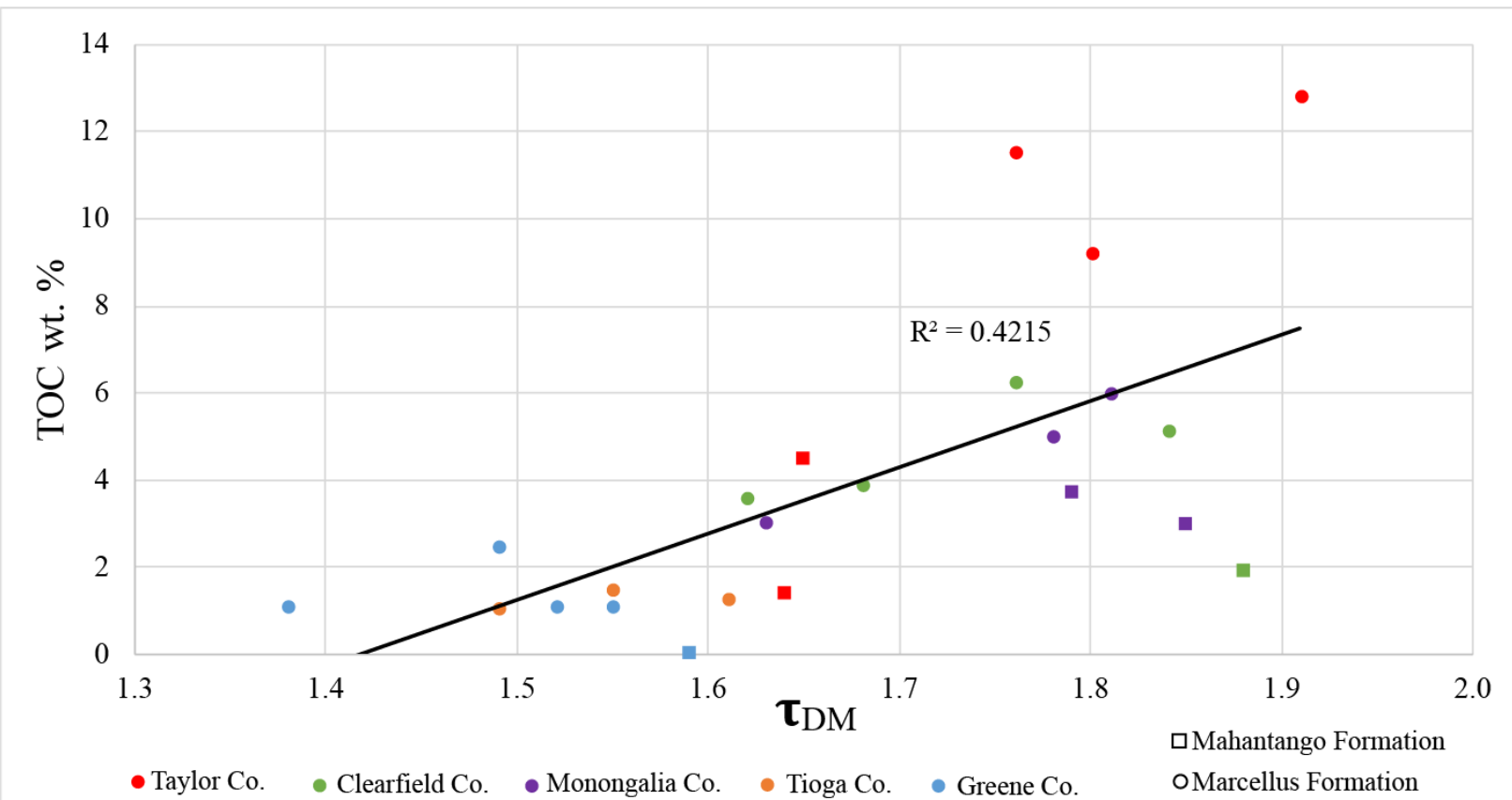

Figure 29. Wt. \% TOC versus $\boldsymbol{\tau}_{\mathrm{DM}}$. Monongalia County data from Hupp (2017), Greene and Tioga County from Phan et al. (2018), and Taylor and Clearfield County data from this study.

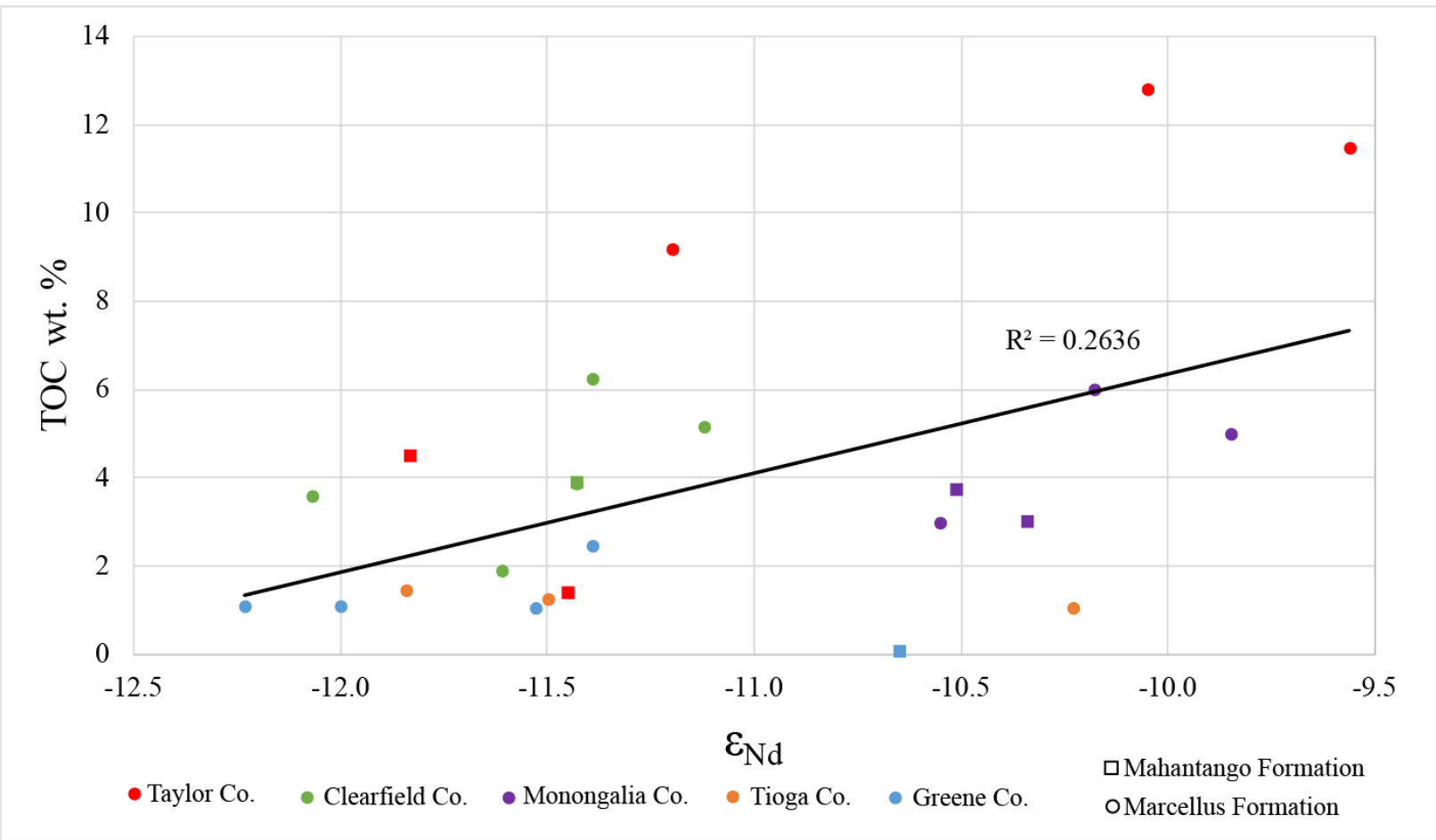

Figure 30. Wt. \% TOC versus $\varepsilon_{\text {Nd. }}$ Monongalia County data from Hupp (2017), Greene and Tioga County from Phan et al. (2018), and Taylor and Clearfield County data from this study. 


\section{CONCLUSIONS}

The geochemical data support the idea that the southern Canadian Grenville Province and/or Superior Craton was/were most likely the original source of some of the sediments for the Hamilton Group. The sediments that make up the Hamilton Group are mostly likely a mix from the Acadian Fold-Thrust Belt and an older source. Whether the older sediments are recycled or straight from the source is still not determined. Sediments that made up the sedimentary rocks in the Acadian Fold-Thrust Belt can contain a similar $\boldsymbol{\tau}_{\mathrm{DM}}$ signature to the southern Canadian Grenville Province and/or Superior Craton because the source of the sediments that made up the older sedimentary units is most likely an older source. The younger $\boldsymbol{\tau}_{\mathrm{DM}}$ ages can be explained by either erosion from the Grenville Inliers or erosion of the younger terranes in the southern Canadian Grenville Province such as the Central Metasedimentary Belt, Quebecia, Morin, Mekinac, or the Adirondacks.

Some future work includes more well locations tested for $\boldsymbol{\tau}_{\mathrm{DM}}$ ages across the basin. Wells in northeastern or northwestern Pennsylvania, central West Virginia, eastern Ohio, or southern Ontario would be helpful in developing a basin-wide model. More ICP-MS analysis could be done on the Coldstream and Armstrong \#1 wells. This would allow more analysis on the sediment recycling problem. It would also give a more in-depth look at the REE concentrations and changes at different intervals of the Marcellus Shale. Lastly, XRD could be done on the intervals sampled in this study to compare mineralogy to the elemental trends. 


\section{REFERENCES}

Armstrong, D.K., 2006, An updated guide to the subsurface Paleozoic stratigraphy of southern Ontario: Toronto, Ontario Geological Survey, Open File Report 6191.

Birchard, M.C., Rutka, M.A., and Brunton, F.R., 2004, Lithofacies and geochemistry of the Lucas Formation in the subsurface of southwestern Ontario: a high-purity limestone and potential high-purity dolostone resource: Sudbury, Ont., Ontario Geological Survey.

Blakey, R., 2009, Middle Devonian North American paleogeographic map, accessed Dec. 2018.

Bock, B., McLennan, S.M., and Hanson, G.N., 1996, The Taconian orogeny in southern New England: Nd-isotope evidence against addition of juvenile components: Canadian Journal of Earth Sciences, v. 33, p. 1612-1627, doi: 10.1139/e96-122.

Bock, B., McLennan, S.M., and Hanson, G.N., 1998, Geochemistry and provenance of the Middle Ordovician Austin Glen Member (Normanskill Formation) and the Taconian Orogeny in New England: Sedimentology, v. 45, p. 635-655, doi: 10.1046/j.13653091.1998.00168.x.

Bonoldi, L., Paolo, L.D., and Flego, C., 2016, Vibrational spectroscopy assessment of kerogen maturity in organic-rich source rocks: Vibrational Spectroscopy, v. 87, p. 14-19, doi: 10.1016/j.vibspec.2016.08.014.

Boswell, R., and Pool, S., 2018, Lithostratigraphy of Middle and Upper Devonian Organic-rich Shales in West Virginia: West Virginia Geological and Economic Survey Reports of Investigation no. 35.

Brett, C.E., Baird, G.C., Bartholomew, A.J., Desantis, M.K., and Straeten, C.A.V., 2011, Sequence stratigraphy and a revised sea-level curve for the Middle Devonian of eastern North America: Palaeogeography, Palaeoclimatology, Palaeoecology, v. 304, p. 21-53, doi: 10.1016/j.palaeo.2010.10.009.

Caesar, W., Mosher, D., Regan, S., Cousens, B., Aspler, L. Chiarenzelli, J., Chiarenzelli, J.R., 2010, Nd model ages and geochemistry of Devonian and Ordovician shales of western and central New York: Geological Society of America- Abstracts with Programs, v. 42, no. 1, p. 72.

Canil, D., 2008, Canada’s craton: a bottoms-up view: GSA Today, v. 18, p. 4-10.

Chakrabarti, R., Abanda, P.A., Hannigan, R.E., and Basu, A.R., 2007, Effects of diagenesis on the Nd-isotopic composition of black shales from the 420 Ma Utica Shale Magnafacies: Chemical Geology, v. 244, p. 221-231, doi: 10.1016/j.chemgeo.2007.06.017.

Chen, R., 2016, Dominant controls on organic-rich shale deposition: Geochemical evidences from the Marcellus Shale in the Appalachian basin [Ph.D. Dissertation]: West Virginia University, 119 p.

Currie, K.L., and Breemen, O.V., 1996, Data on the origin of the Kipawa Syenite Complex, northwestern Quebec: The Canadian Mineralogist, v. 34, p. 435-451, doi: $10.4095 / 209524$. 
DePaolo, D.J., 1981, Neodymium isotopes in the Colorado Front Range and crust-mantle evolution in the Proterozoic: Nature, v. 291, p. 193-196, doi: 10.1038/291193a0.

DePaolo, D.J., and Wasserburg, G.J., 1976, Nd isotopic variations and petrogenetic models: Geophysical Research Letters, v. 3, p. 249-252, doi: 10.1029/gl003i005p00249.

Drewry, G.E., Ramsay, A.T.S., and Smith, A.G., 1976, Climatically controlled sediments, the geomagnetic field, and trade wind belts in Phanerozoic time: A Reply: The Journal of Geology, v. 84, p. 374-375, doi: 10.1086/628203.

D’Hulst, A., Beaudoin, G., Malo, M., Constantin, M., and Pilote, P., 2008, Geochemistry of Sainte-Marguerite volcanic rocks: implications for the evolution of Silurian-Devonian volcanism in the Gaspé Peninsula: Canadian Journal of Earth Sciences, v. 45, p. 15-29, doi: 10.1139/e07-012.

Eriksson, K.A., Campbell, I.H., Palin, J.M., Allen, C.M., and Bock, B., 2004, Evidence for Multiple Recycling in Neoproterozoic through Pennsylvanian Sedimentary Rocks of the Central Appalachian Basin: The Journal of Geology, v. 112, p. 261-276, doi: $10.1086 / 382758$.

Ettensohn, F.R., 1985, Controls on development of Catskill Delta complex basin-facies: Geological Society of America Special Papers, p. 65-78, doi: 10.1130/spe201-p65.

Eyles, N., Boyce, J., and Mohajer, A.A., 1993, The bedrock surface of the western Lake Ontario region: Evidence of reactivated basement structures?: Géographie physique et Quaternaire, v. 47, p. 269, doi: 10.7202/032957ar.

Faill, R.T., 1985, The Acadian orogeny and the Catskill Delta: Geological Society of America Special Papers, p. 15-38, doi: 10.1130/spe201-p15.

Feng, J.L., Zhu, L.P., Zhen, X.L., and Hu, Z.G., 2009, Grain size effect on Sr and Nd isotopic compositions in eolian dust: Implications for tracing dust provenance and Nd model age: Geochemical Journal, v. 43, p. 123-131, doi: 10.2343/geochemj.1.0007.

Ferrari, A.C., and Robertson, J., 2000, Interpretation of Raman spectra of disordered and amorphous carbon: Physical Review B, v. 61, p. 14095-14107, doi: 10.1103/physrevb.61.14095.

Harper, J.A., and Piotrowski, R.G., 1978, Stratigraphy, extent, gas production, and future gas potential of the Devonian organic-rich shales in Pennsylvania: Second Eastern Gas Shales Symposium, p. 310-329.

Harper, J.A., 1989, Effects of recurrent tectonic patterns on the occurrence and development of oil and gas resources in western Pennsylvania: Northeastern Geology, v. 11, p. 225-245.

Hatfield, C.B., Rohrbacher, T.J., and Floyd, J.C., 1968, Directional properties, paleoslope, and source of the Sylvania Sandstone (Middle Devonian) of southeastern Michigan and northwestern Ohio: Journal of Sedimentary Petrology, v. 38, p. 224-228.

Horowitz, A.S., and Potter, P.E., 1971, Introductory petrography of fossils: Berlin, Springer. 
Hurowitz, J.A., and McLennan, S.M., 2005, Geochemistry of Cambro-Ordovician sedimentary rocks of the northeastern United States: Changes in sediment sources at the onset of Taconian orogenesis: The Journal of Geology, v. 113, p. 571-587, doi: 10.1086/431910.

Hupp, B.N., 2017, Provenance of the Hamilton Group: A study of source-to-sink relationships within the Middle Devonian central Appalachian Basin [Masters thesis]: West Virginia University, $128 \mathrm{p}$.

Hupp, B.N., and Weislogel, A.L., 2018, Geochemical insights into provenance of the Middle Devonian Hamilton Group of the central Appalachian Basin, U.S.A.: Journal of Sedimentary Research, v. 88, p. 1153-1165, doi: 10.2110/jsr.2018.62.

Kohl, D., Slingerland, R., Arthur, M., Bracht, R., and Engelder, T., 2014, Sequence stratigraphy and depositional environments of the Shamokin (Union Springs) Member, Marcellus Formation, and associated strata in the middle Appalachian Basin: AAPG Bulletin, v. 98, p. 483-513, doi: 10.1306/08231312124.

Lash, G.G., and Engelder, T., 2011, Thickness trends and sequence stratigraphy of the Middle Devonian Marcellus Formation, Appalachian Basin: Implications for Acadian foreland basin evolution: AAPG Bulletin, v. 95, p. 61-103, doi: 10.1306/06301009150.

Lash, G.G., and Blood, D.R., 2014, Organic matter accumulation, redox, and diagenetic history of the Marcellus Formation, southwestern Pennsylvania, Appalachian basin: Marine and Petroleum Geology, v. 57, p. 244-263, doi: 10.1016/j.marpetgeo.2014.06.001.

Laughrey, C., and Harper, J., 1986, Comparisons of Upper Devonian and Lower Silurian tight formations in Pennsylvania-Geological and Engineering Characteristics: Geology of Tight Gas Reservoirs, v. 24, p. 9-43.

Lipin, B.R., McKay, G.A., and Boynton, W.V., 1989, Geochemistry and mineralogy of rare earth elements: Washington, D.C., Mineralogical Society of America.

Liu, D., Xiao, X., Tian, H., Min, Y., Zhou, Q., Cheng, P., and Shen, J., 2012, Sample maturation calculated using Raman spectroscopic parameters for solid organics: Methodology and geological applications: Chinese Science Bulletin, v. 58, p. 1285-1298, doi: 10.1007/s11434-012-5535-y.

Lupoi, J.S., Fritz, L.P., Parris, T.M., Hackley, P.C., Solotky, L., Eble, C.F., and Schlaegle, S., 2017, Assessment of thermal maturity trends in Devonian-Mississippian source rocks using Raman spectroscopy: Limitations of peak-fitting method: Frontiers in Energy Research, v. 5, doi: 10.3389/fenrg.2017.00024.

Lupoi, J.S., Fritz, L.P., Hackley, P.C., Solotky, L., Weislogel, A., and Schlaegle, S., 2018, Quantitative evaluation of vitrinite reflectance and atomic O/C in coal using Raman spectroscopy and multivariate analysis: Fuel, v. 230, p. 1-8, doi: 10.1016/j.fuel.2018.04.172.

Martignole, J., and Reynolds, P., 1997, 40Ar/39Ar thermochronology along a western Québec transect of the Grenville Province, Canada: Journal of Metamorphic Geology, v. 15, p. 283-296, doi: 10.1111/j.1525-1314.1997.00018.x. 
McDonough, W.F., and Sun, S.S., 1995, The Composition of the Earth: Chemical Geology, v. 120, p. 223-253, doi: 10.1016/0009-2541(94)00140-4.

McLelland, J.M., Selleck, B.W., and Bickford, M., 2010, Review of the Proterozoic evolution of the Grenville Province, its Adirondack outlier, and the Mesoproterozoic inliers of the Appalachians: Geological Society of America Memoirs From Rodinia to Pangea: The Lithotectonic Record of the Appalachian Region, p. 21-49, doi: 10.1130/2010.1206(02).

McLennan, S.M., 2001, Relationships between the trace element composition of sedimentary rocks and upper continental crust: Geochemistry, Geophysics, Geosystems, v. 2, doi: 10.1029/2000gc000109.

McLennan, S.M., Taylor, M.T., McCulloch, M.T., and Maynard, J.B., 1990, Geochemical and Nd-Sm isotopic composition of deep-sea turbidites: Crustal evolution and plate tectonic associations: Geochimica et Cosmochimica Acta, v. 54, p. 2015-2050

McLennan, S.M., Hemming, S., McDaniel, D.K., and Hanson, G.N., 1993, Geochemical approaches to sedimentation, provenance, and tectonics: processes controlling the composition of clastic sediments: Geological Society of America Special Papers, p. 2140, doi: 10.1130/spe284-p21.

Milliken, K.L., 2014, A compositional classification for grain assemblages in fine-grained sediments and sedimentary rocks-Reply: Journal of Sedimentary Research, v. 84, p. 1185-1199, doi: 10.2110/jsr.2016.2.

Mintz, J.S., Driese, S.G., and White, J.D., 2010, Environmental and ecological variability of Middle Devonian (Givetian) forests in Appalachian Basin paleosols, New York, United States: Palaios, v. 25, p. 85-96, doi: 10.2110/palo.2009.p09-086r.

MSEEL Gas Production for MIP-3H, Marcellus Shale Energy and Environment Laboratory, http://mseel.org/ (accessed March 2019).

Murphy, A.E., Sageman, B.B., Straeten, C.A.V., and Hollander, D.J., 2000, Organic carbon burial and faunal dynamics in the Appalachian Basin during the Devonian (GivetianFamennian) greenhouse: an integrated paleoecological and biogeochemical approach: warm climates in Earth History, p. 351-385, doi: 10.1017/cbo9780511564512.013

Murphy, J.B., Staal, C.R.V., and Keppie, J.D., 1999, Middle to late Paleozoic Acadian orogeny in the northern Appalachians: A Laramide-style plume-modified orogeny?: Geology, v. 27, p. 653, doi: 10.1130/0091-7613(1999)027<0653:mtlpao>2.3.co;2.

Nelson, B.K., and DePaolo, D.J., 1988, Comparison of Isotopic and Petrographic Provenance Indicators in Sediments from Tertiary Continental Basins of New Mexico: SEPM Journal of Sedimentary Research, v. Vol. 58, doi: 10.1306/212f8d91-2b24-11d78648000102c1865d.

Nesbitt, H.W., and Young, G.M., 1982, Early Proterozoic climates and plate motions inferred from major element chemistry of lutites: Nature, v. 299, p. 715-717, doi: 10.1038/299715a0. 
Ohr, M., Halliday, A.N., and Peacor, D.R., 1994, Mobility and fractionation of rare earth elements in argillaceous sediments: Implications for dating diagenesis and low-grade metamorphism: Geochimica et Cosmochimica Acta, v. 58, p. 289-312, doi: 10.1016/0016-7037(94)90465-0.

Oil and Gas Reports, Pennsylvania Department of Environmental Protection, https://www.dep.pa.gov/DataandTools/Reports/Oil and Gas reports/Pages/default.aspx (accessed March 2019).

Park, H., Barbeau, D.L.B., Rickenbaker, A., Bachmann-Krug, D., and Gehrels, G., 2010, Application of foreland basin detrital-zircon geochronology to the reconstruction of the southern and central Appalachian Orogen: The Journal of Geology, v. 118, p. 23-44, doi: 10.1086/648400.

Paronish, T.J., 2018, Meso- and macro-Scale facies and chemostratigraphic analysis of Middle Devonian Marcellus Shale in northern West Virginia, USA [Masters thesis]: West Virginia University, 383 p.

Parrish, C.B., 2013, Insights into the Appalachian Basin Middle Devonian depositional system from U-Pb zircon geochronology of volcanic ashes in the Marcellus Shales and Onondaga Limestone [Masters Thesis]: West Virginia University, Morgantown, West Virginia, 149 p.

Patchett, P.J., Ross, G.M., and Gleason, J.D., 1999, Continental drainage in North America during the Phanerozoic from Nd Isotopes: Science, v. 283, p. 671-673, doi: 10.1126/science.283.5402.671.

Percival, J.A., Sanborn-Barrie, M., Skulski, T., Stott, G.M., Helmstaedt, H., and White, D.J., 2006, Tectonic evolution of the western Superior Province from NATMAP and Lithoprobe studies: Canadian Journal of Earth Sciences, v. 43, p. 1085-1117, doi: 10.1139/e06-062.

Phan, T.T., Gardiner, J.B., Capo, R.C., and Stewart, B.W., 2018, Geochemical and multi-isotopic (87 Sr/ 86 Sr, 143 Nd/ 144 Nd, 238 U/ 235 U) perspectives of sediment sources, depositional conditions, and diagenesis of the Marcellus Shale, Appalachian Basin, USA: Geochimica et Cosmochimica Acta, v. 222, p. 187-211, doi: 10.1016/j.gca.2017.10.021.

Pinet, N., 2016, Far-field effects of Appalachian orogenesis: A view from the craton: Geology, v. 44, p. 83-86, doi: 10.1130/g37356.1.

Prevec, S.A., 2004, Basement tracing using Mid-Proterozoic anorthosites straddling a palaeoterrane boundary, Ontario, Canada: Precambrian Research, v. 129, p. 169-184, doi: 10.1016/j.precamres.2003.10.009.

Queen, M., Hanes, J.A., Archibald, D.A., Farrar, E., and Heaman, L.M., 1996, 40Ar/39Ar phlogopite and $\mathrm{U}-\mathrm{Pb}$ perovskite dating of lamprophyre dykes from the eastern Lake Superior region: evidence for a 1.14 Ga magmatic precursor to Midcontinent Rift volcanism: Canadian Journal of Earth Sciences, v. 33, p. 958-965, doi: 10.1139/e96-072. 
Rahl, J., Anderson, K., Brandon, M., and Fassoulas, C., 2005, Raman spectroscopic carbonaceous material thermometry of low-grade metamorphic rocks: Calibration and application to tectonic exhumation in Crete, Greece: Earth and Planetary Science Letters, v. 240, p. 339-354, doi: 10.1016/j.epsl.2005.09.055.

Repetski, J.E., Ryder, R.T., Weazy, D.J., Harris, A.G., and Trippi, M.H., 2008, Thermal maturity patterns (CAI and \% Ro) in Ordovician and Devonian rocks of the Appalachian Basin: A major revision of U.S. Geological Survey Map I-917 using new subsurface collections: U.S. Geological Survey Scientific Investigations Map 3006.

Roser, B.P., and Korsch, R.J., 1988, Provenance signatures of sandstone-mudstone suites determined using discriminant function analysis of major-element data: Chemical Geology, v. 67, p. 119-139.

Ryder, R.T., Trippi, M.H., Swezey, C.S., Crangle, R.D., Jr., Hope, R.S., Rowan, E.L., and Lentz, E.E., 2012, Geologic cross section C-C' through the Appalachian Basin from Erie County, north-central Ohio, to the Valley and Ridge province, Bedford County, southcentral Pennsylvania: U.S. Geological Survey Scientific Investigations Map 3172, 2 sheets, 70 p. pamphlet.

Sageman, B.B., Murphy, A.E., Werne, J.P., Straeten, C.A.V., Hollander, D.J., and Lyons, T.W., 2003, A tale of shales: the relative roles of production, decomposition, and dilution in the accumulation of organic-rich strata, Middle-Upper Devonian, Appalachian basin: Chemical Geology, v. 195, p. 229-273, doi: 10.1016/s0009-2541(02)00397-2.

Sanford, B.V., Thompson, F.J., and McFall, G.H., 1985, Plate tectonics -- A possible controlling mechanism in the development of hydrocarbon traps in Southwestern Ontario: Bulletin of Canadian Petroleum Geology, v. 33, p. 52-71.

Sauerer, B., Craddock, P.R., Aljohani, M.D., Alsamadony, K.L., and Abdallah, W., 2017, Fast and accurate shale maturity determination by Raman spectroscopy measurement with minimal sample preparation: International Journal of Coal Geology, v. 173, p. 150-157, doi: 10.1016/j.coal.2017.02.008.

Schito, A., Romano, C., Corrado, S., Grigo, D., and Poe, B., 2017, Diagenetic thermal evolution of organic matter by Raman spectroscopy: Organic Geochemistry, v. 106, p. 57-67, doi: 10.1016/j.orggeochem.2016.12.006.

Schoonmaker, A., Kidd, W.S.F., Reusch, D.N., Dorias, M.J., Gregg, T., and Spencer, C., 2011, Stratigraphic context, geochemical, and isotopic properties of magmatism in the SiluroDevonian inliers of northern Maine: implications for the Acadian Orogeny: American Journal of Science, v. 311, p. 528-572.

Selleck, B.W., Chiarenzelli, J., Kratzmann, D.J., Christoffersen, P., and Durham, A., 2014, Detrital zircon geochronology and provenance of Middle and Upper Devonian strata, northern Appalachian Basin of New York State: Geological Society of AmericaAbstracts with Programs, v. 46, no. 2, p. 98. 
Taylor, S.R., Rudnick, R.L., Mclennan, S.M., and Eriksson, K.A., 1986, Rare earth element patterns in Archean high-grade metasediments and their tectonic significance: Geochimica et Cosmochimica Acta, v. 50, p. 2267-2279, doi: 10.1016/00167037(86)90081-5.

Tollo, R.P., Aleinikoff, J.N., Borduas, E.A., Hackley, P.C., and Fanning, C.M., 2004, Petrologic and geochronologic evolution of the Grenville orogen, northern Blue Ridge Province, Virginia: Memoir 197: Proterozoic Tectonic Evolution of the Grenville Orogen in North America, p. 647-677, doi: 10.1130/0-8137-1197-5.647.

Ver Straeten, C.A., Brett, C.E., and Sageman, B.B., 2011, Mudrock sequence stratigraphy: A multi-proxy (sedimentological, paleobiological and geochemical) approach, Devonian Appalachian Basin: Palaeogeography, Palaeoclimatology, Palaeoecology, v. 304, p. 5473, doi: 10.1016/j.palaeo.2010.10.010.

Volkert, R.A., Feigenson, M.D., Patino, L.C., Delaney, J.S., and Drake, A.A., 2000, Sr and Nd isotopic compositions, age and petrogenesis of A-type granitoids of the Vernon Supersuite, New Jersey Highlands, USA: Lithos, v. 50, p. 325-347, doi: 10.1016/s00244937(99)00065-1.

Weicht, D., 2015, 3D Seismic, Mechanical Stratigraphy, and Petrophysical Analysis of the Marcellus Shale in Taylor County, West Virginia [Masters thesis]: West Virginia University, 77 p..

Wendell, C., Mosher, D., Regan, S., Cousens, B.L., Aspler L.B., Chiarenzelli, J. and Chiarenzelli J.R., 2010, Geochemical and Isotopic Characterization of Potential Gas Bearing Units of the Utica and Marcellus Shale, New York: Geological Society of America- Abstracts with Programs, v. 42, no. 1, p. 63.

Werne, J.P., Sageman, B.B., Lyons, T.W., and Hollander, D., 2002, An integrated assessment of a "type euxinic" deposit: Evidence for multiple controls on black shale deposition in the middle Devonian Oatka Creek Formation: American Journal of Science, v. 302, p. 110 143, doi: 10.2475/ajs.302.2.110.

Wonnell, C.S., 2015, Lithofacies and sequence stratigraphy of the Middle Devonian Marcellus Formation for a cored well in Clearfield County, Pennsylvania using core analysis methods [Masters thesis]: West Virginia University, 114 p.

Woodrow, D.L., 1985, Paleogeography, paleoclimate, and sedimentary processes of the Late Devonian Catskill Delta: Geological Society of America Special Papers, p. 51-64, doi: 10.1130/spe201-p51.

WVDEP Office of Oil \& Gas Well Information, http://tagis.dep.wv.gov/oog/ (accessed March 2019).

Zagorski, William A., Emery, M., and Ventura, J. L., 2017, The Marcellus Shale Play: Its discovery and emergence as a major global hydrocarbon accumulation, in R. K. Merrill and C. A. Sternbach, eds., Giant fields of the decade 2000-2010: AAPG Memoir 113, p. 55-90. 


\section{APPENDICES}

APPENDIX I. ICP-MS elemental concentrations (weight percent and parts per million) of the samples collected from the Armstrong (A) and Coldstream (C) wells. $\mathrm{Fe}_{2} \mathrm{O}_{3}$ represents total iron.

\begin{tabular}{|c|c|c|c|c|c|c|c|c|c|c|c|c|}
\hline Element & $\begin{array}{c}\text { Unit } \\
\text { Symbol }\end{array}$ & $\begin{array}{c}\text { Detection } \\
\text { Limit }\end{array}$ & $\begin{array}{c}\text { A- } \\
7660\end{array}$ & $\begin{array}{c}\text { A- } \\
7670\end{array}$ & $\begin{array}{c}\text { A- } \\
7705 \\
\end{array}$ & $\begin{array}{c}\text { A- } \\
7730 \\
\end{array}$ & $\begin{array}{c}\text { A- } \\
7760 \\
\end{array}$ & $\begin{array}{c}\text { C- } \\
7032 \\
\end{array}$ & $\begin{array}{c}\text { C- } \\
7060\end{array}$ & $\begin{array}{c}\text { C- } \\
7075\end{array}$ & $\begin{array}{c}\text { C- } \\
7110 \\
\end{array}$ & $\begin{array}{c}\text { C- } \\
7144 \\
\end{array}$ \\
\hline $\mathrm{SiO}_{2}$ & $\%$ & 0.01 & 56.93 & 62.04 & 56.4 & 60.39 & 35.13 & 54.42 & 54.65 & 52.83 & 57.47 & 58.31 \\
\hline $\mathbf{A l}_{2} \mathbf{O}_{3}$ & $\%$ & 0.01 & 15.61 & 15.74 & 19.32 & 11.02 & 6.32 & 16.05 & 17.71 & 19.29 & 14.16 & 15.22 \\
\hline $\mathrm{Fe}_{2} \mathrm{O}_{3}(\mathrm{~T})$ & $\%$ & 0.01 & 6.46 & 5.77 & 5.62 & 4.12 & 4.17 & 6.25 & 6.07 & 5.99 & 6.06 & 5.67 \\
\hline MnO & $\%$ & 0.001 & 0.071 & 0.039 & 0.029 & 0.021 & 0.027 & 0.061 & 0.043 & 0.027 & 0.028 & 0.028 \\
\hline MgO & $\%$ & 0.01 & 1.63 & 1.33 & 1.42 & 0.95 & 0.83 & 2.08 & 1.69 & 1.49 & 1.26 & 1.34 \\
\hline $\mathrm{CaO}$ & $\%$ & 0.01 & 3.07 & 1.01 & 0.7 & 2.34 & 22.08 & 5.03 & 3.51 & 0.49 & 2.69 & 2.01 \\
\hline $\mathrm{Na}_{2} \mathrm{O}$ & $\%$ & 0.01 & 0.57 & 0.58 & 0.62 & 0.52 & 0.36 & 0.59 & 0.68 & 0.71 & 0.66 & 0.69 \\
\hline $\mathrm{K}_{2} \mathrm{O}$ & $\%$ & 0.01 & 3.8 & 3.82 & 4.57 & 2.76 & 1.6 & 3.72 & 4.09 & 4.61 & 3.46 & 3.8 \\
\hline $\mathrm{TiO}_{2}$ & $\%$ & 0.001 & 0.61 & 0.652 & 0.708 & 0.479 & 0.258 & 0.677 & 0.642 & 0.718 & 0.657 & 0.745 \\
\hline $\mathbf{P}_{2} \mathbf{O}_{5}$ & $\%$ & 0.01 & 0.06 & 0.06 & 0.07 & 0.09 & 0.07 & 0.1 & 0.1 & 0.07 & 0.06 & 0.08 \\
\hline LOI & $\%$ & - & 9.78 & 8.92 & 10.79 & 17.66 & 24.23 & 10.46 & 9.86 & 13.43 & 11.82 & 11.69 \\
\hline Total & $\%$ & 0.01 & 98.59 & 99.98 & 100.2 & 100.3 & 95.7 & 99.44 & 99.05 & 99.66 & 98.32 & 99.58 \\
\hline Sc & ppm & 1 & 17 & 16 & 20 & 17 & 11 & 19 & 20 & 20 & 17 & 17 \\
\hline $\mathbf{B e}$ & ppm & 1 & 3 & 3 & 4 & 3 & 2 & 3 & 3 & 4 & 3 & 3 \\
\hline V & $\mathrm{ppm}$ & 5 & 197 & 349 & 318 & 720 & 841 & 187 & 167 & 333 & 418 & 317 \\
\hline $\mathrm{Cr}$ & $\mathrm{ppm}$ & 20 & 90 & 90 & 100 & 80 & 70 & 100 & 100 & 110 & 80 & 90 \\
\hline Co & $\mathrm{ppm}$ & 1 & 17 & 17 & 18 & 19 & 23 & 14 & 21 & 20 & 21 & 21 \\
\hline $\mathbf{N i}$ & $\mathrm{ppm}$ & 20 & 80 & 80 & 140 & 200 & 210 & 60 & 60 & 150 & 160 & 130 \\
\hline $\mathrm{Cu}$ & ppm & 10 & 100 & 80 & 110 & 180 & 170 & 50 & 90 & 110 & 90 & 100 \\
\hline Zn & $\mathrm{ppm}$ & 30 & 80 & $<30$ & 100 & 1880 & 190 & 80 & 40 & 220 & 120 & 60 \\
\hline Ga & ppm & 1 & 22 & 22 & 25 & 15 & 10 & 23 & 23 & 26 & 20 & 21 \\
\hline Ge & $\mathrm{ppm}$ & 1 & $<1$ & $<1$ & $<1$ & 2 & $<1$ & $<1$ & $<1$ & $<1$ & $<1$ & $<1$ \\
\hline As & $\mathrm{ppm}$ & 5 & 16 & 6 & 17 & 29 & 37 & $<5$ & $<5$ & 16 & 19 & 11 \\
\hline Rb & $\mathrm{ppm}$ & 2 & 177 & 181 & 213 & 120 & 64 & 174 & 196 & 227 & 160 & 169 \\
\hline
\end{tabular}




\begin{tabular}{|c|c|c|c|c|c|c|c|c|c|c|c|c|}
\hline Element & \begin{tabular}{|c|} 
Unit \\
Symbol
\end{tabular} & $\begin{array}{c}\text { Detection } \\
\text { Limit }\end{array}$ & $\begin{array}{c}\text { A- } \\
7660\end{array}$ & $\begin{array}{c}\text { A- } \\
7670\end{array}$ & $\begin{array}{c}\text { A- } \\
7705\end{array}$ & $\begin{array}{c}\text { A- } \\
7730\end{array}$ & $\begin{array}{c}\text { A- } \\
7760\end{array}$ & $\begin{array}{c}\text { C- } \\
7032\end{array}$ & $\begin{array}{c}\text { C- } \\
7060\end{array}$ & $\begin{array}{c}\text { C- } \\
7075\end{array}$ & $\begin{array}{c}\text { C- } \\
7110\end{array}$ & $\begin{array}{c}\text { C- } \\
7144\end{array}$ \\
\hline $\mathrm{Sr}$ & ppm & 2 & 118 & 108 & 122 & 120 & 392 & 275 & 283 & 218 & 248 & 297 \\
\hline $\mathbf{Y}$ & ppm & 2 & 26 & 27 & 32 & 42 & 103 & 31 & 30 & 24 & 28 & 35 \\
\hline $\mathrm{Zr}$ & $\mathrm{ppm}$ & 4 & 96 & 103 & 105 & 101 & 54 & 112 & 106 & 115 & 108 & 123 \\
\hline $\mathbf{N b}$ & $\mathrm{ppm}$ & 1 & 9 & 9 & 10 & 7 & 4 & 11 & 10 & 11 & 8 & 10 \\
\hline Mo & $\mathrm{ppm}$ & 2 & 30 & 35 & 86 & 193 & 101 & 13 & 7 & 103 & 84 & 73 \\
\hline Ag & $\mathrm{ppm}$ & 0.5 & $<0.5$ & $<0.5$ & $<0.5$ & 0.6 & 0.9 & $<0.5$ & $<0.5$ & 0.5 & $<0.5$ & 0.9 \\
\hline In & $\mathrm{ppm}$ & 0.2 & $<0.2$ & $<0.2$ & $<0.2$ & $<0.2$ & $<0.2$ & $<0.2$ & $<0.2$ & $<0.2$ & $<0.2$ & $<0.2$ \\
\hline Sn & ppm & 1 & 2 & 1 & 2 & 2 & $<1$ & 2 & 2 & 1 & $<1$ & 1 \\
\hline Sb & $\mathrm{ppm}$ & 0.5 & 2.3 & 1.4 & 3.8 & 9.4 & 5.3 & 0.8 & $<0.5$ & 2.5 & 2.6 & 2.7 \\
\hline Cs & $\mathrm{ppm}$ & 0.5 & 9.5 & 9.7 & 13.3 & 9.2 & 4.2 & 9.3 & 11 & 13.7 & 9.1 & 9.7 \\
\hline Ba & ppm & 3 & 786 & 862 & 1089 & 764 & 550 & 788 & 846 & 1155 & 820 & 874 \\
\hline $\mathbf{B i}$ & $\mathrm{ppm}$ & 0.4 & $<0.4$ & $<0.4$ & $<0.4$ & $<0.4$ & $<0.4$ & $<0.4$ & $<0.4$ & $<0.4$ & $<0.4$ & $<0.4$ \\
\hline La & ppm & 0.1 & 35.9 & 36.9 & 38.8 & 35.3 & 74.7 & 38.4 & 39 & 38.3 & 35 & 41 \\
\hline Ce & $\mathrm{ppm}$ & 0.1 & 69.1 & 70.4 & 74.7 & 61.2 & 103 & 75.1 & 77.9 & 72 & 67 & 78.4 \\
\hline Pr & $\mathrm{ppm}$ & 0.05 & 8.28 & 8.49 & 9.52 & 9.23 & 15.1 & 9.2 & 9.8 & 8.54 & 8.19 & 9.48 \\
\hline Nd & ppm & 0.1 & 31.7 & 32.9 & 36.4 & 37.3 & 61.3 & 35 & 36.8 & 30.5 & 31.3 & 35.2 \\
\hline $\mathrm{Sm}$ & $\mathrm{ppm}$ & 0.1 & 6.2 & 6.4 & 7.5 & 8.3 & 13.1 & 7.2 & 8.1 & 5.6 & 6 & 7.2 \\
\hline Eu & $\mathrm{ppm}$ & 0.05 & 1.27 & 1.21 & 1.65 & 1.83 & 3.11 & 1.56 & 1.71 & 1.22 & 1.24 & 1.37 \\
\hline Gd & ppm & 0.1 & 5 & 4.8 & 6.4 & 8.2 & 14.8 & 6.6 & 6.7 & 4.4 & 5.1 & 6.1 \\
\hline Tb & $\mathrm{ppm}$ & 0.1 & 0.8 & 0.8 & 1 & 1.3 & 2.3 & 1 & 1.1 & 0.7 & 0.8 & 1 \\
\hline Dy & $\mathrm{ppm}$ & 0.1 & 4.5 & 4.9 & 5.8 & 7.8 & 14.7 & 5.9 & 6.4 & 4.5 & 5.1 & 6.1 \\
\hline Ho & $\mathrm{ppm}$ & 0.1 & 0.9 & 1 & 1.1 & 1.5 & 3.2 & 1.1 & 1.2 & 0.9 & 1 & 1.2 \\
\hline Er & ppm & 0.1 & 2.6 & 2.8 & 3 & 4.5 & 9.5 & 3.3 & 3.3 & 2.7 & 2.9 & 3.5 \\
\hline Tm & $\mathrm{ppm}$ & 0.05 & 0.4 & 0.4 & 0.47 & 0.62 & 1.41 & 0.48 & 0.49 & 0.38 & 0.45 & 0.5 \\
\hline $\mathbf{Y b}$ & $\mathrm{ppm}$ & 0.1 & 2.6 & 2.6 & 3 & 3.9 & 10.5 & 3.1 & 3.1 & 2.5 & 2.9 & 3.5 \\
\hline $\mathbf{L u}$ & ppm & 0.04 & 0.39 & 0.44 & 0.44 & 0.57 & 1.71 & 0.44 & 0.49 & 0.41 & 0.42 & 0.53 \\
\hline Hf & ppm & 0.2 & 2.4 & 2.7 & 2.7 & 2.1 & 1.3 & 2.9 & 2.8 & 2.8 & 2.6 & 3.3 \\
\hline
\end{tabular}




\begin{tabular}{|c|c|c|c|c|c|c|c|c|c|c|c|c|}
\hline Element & $\begin{array}{c}\text { Unit } \\
\text { Symbol }\end{array}$ & $\begin{array}{c}\text { Detection } \\
\text { Limit }\end{array}$ & $\begin{array}{c}\text { A- } \\
7660\end{array}$ & $\begin{array}{c}\text { A- } \\
7670\end{array}$ & $\begin{array}{c}\text { A- } \\
7705\end{array}$ & $\begin{array}{c}\text { A- } \\
7730\end{array}$ & $\begin{array}{c}\text { A- } \\
7760\end{array}$ & $\begin{array}{c}\text { C- } \\
7032\end{array}$ & $\begin{array}{c}\text { C- } \\
7060\end{array}$ & $\begin{array}{c}\text { C- } \\
7075\end{array}$ & $\begin{array}{c}\text { C- } \\
7110\end{array}$ & $\begin{array}{c}\text { C- } \\
7144 \\
\end{array}$ \\
\hline Ta & $\mathrm{ppm}$ & 0.1 & 0.9 & 0.9 & 0.9 & 0.5 & 0.2 & 1 & 0.9 & 1.1 & 0.9 & 1 \\
\hline $\mathbf{W}$ & ppm & 1 & $<1$ & $<1$ & $<1$ & 6 & $<1$ & $<1$ & $<1$ & 6 & $<1$ & $<1$ \\
\hline Tl & $\mathrm{ppm}$ & 0.1 & 1.4 & 2.4 & 3.2 & 6.2 & 3.7 & 1.3 & 1.2 & 2.1 & 1.6 & 1.5 \\
\hline $\mathbf{P b}$ & $\mathrm{ppm}$ & 5 & 14 & 6 & $<5$ & 27 & $<5$ & 8 & 10 & $<5$ & $<5$ & 6 \\
\hline Th & $\mathrm{ppm}$ & 0.1 & 9.7 & 10.4 & 10.5 & 7.1 & 4.1 & 10.2 & 10.3 & 11.2 & 9.8 & 11 \\
\hline $\mathbf{U}$ & $\mathrm{ppm}$ & 0.1 & 5.8 & 6.3 & 17.1 & 46.6 & 49.5 & 5.1 & 5.7 & 25.6 & 15.9 & 13.9 \\
\hline
\end{tabular}


APPENDIX II. Thin section petrography results. Armstrong \#1 well samples abbreviated “A” and CSA well samples “C”.

\begin{tabular}{|c|c|c|c|c|c|c|c|c|c|}
\hline Sample & $\begin{array}{c}\text { Picture } \\
\#\end{array}$ & $\begin{array}{c}\text { Quartz } \\
\text { Grain } \\
\text { Size }\end{array}$ & $\begin{array}{l}\text { Quartz } \\
\text { Grain } \\
\text { Shape }\end{array}$ & $\begin{array}{c}\text { Sedimentary } \\
\text { Structures }\end{array}$ & Fossils & $\begin{array}{l}\text { Other } \\
\text { Details }\end{array}$ & Objective & Light Type & $\begin{array}{c}\text { Milliken } \\
\text { (2014) } \\
\text { Classification } \\
\end{array}$ \\
\hline $\begin{array}{c}\text { A-7660 } \\
\text { (A) }\end{array}$ & 1 & $\begin{array}{c}\text { silt } \\
(0.012 \\
\mathrm{mm})\end{array}$ & sub-angular & laminations & $\begin{array}{l}\text { compressed } \\
\text { longitudinal } \\
\text { benthic } \\
\text { foraminifera } \\
\text { (1) }\end{array}$ & $\begin{array}{c}\text { less } \\
\text { framboids, } \\
\text { more } \\
\text { euhedral } \\
\text { pyrite }\end{array}$ & $20 x$ & transmitted & calcareous tarl \\
\hline $\begin{array}{c}\text { A-7660 } \\
\text { (B) }\end{array}$ & 2 & $\begin{array}{c}\text { silt } \\
(0.012 \\
\mathrm{mm})\end{array}$ & sub-angular & laminations & $\begin{array}{l}\text { compressed } \\
\text { longitudinal } \\
\text { benthic } \\
\text { foraminifera } \\
\text { (1) }\end{array}$ & & $20 \mathrm{x}$ & reflected & calcareous tarl \\
\hline $\begin{array}{l}\text { A-7670 } \\
\text { (C) }\end{array}$ & 1 & $\begin{array}{c}\text { silt } \\
(0.012 \\
\mathrm{mm})\end{array}$ & sub-angular & $\begin{array}{c}\text { faint } \\
\text { laminations }\end{array}$ & & $\begin{array}{c}\text { some } \\
\text { euhedral } \\
\text { pyrite }\end{array}$ & $20 \mathrm{x}$ & reflected & siliceous tarl \\
\hline $\begin{array}{c}\text { A-7670 } \\
\text { (D) }\end{array}$ & 2 & $\begin{array}{c}\text { silt } \\
(0.012 \\
\mathrm{mm})\end{array}$ & sub-angular & $\begin{array}{c}\text { faint } \\
\text { laminations }\end{array}$ & & $\begin{array}{l}\text { elongated } \\
\text { grains in } \\
\text { bedding } \\
\text { orientation }\end{array}$ & $20 \mathrm{x}$ & transmitted & siliceous tarl \\
\hline $\begin{array}{c}\text { A-7705 } \\
\text { (E) }\end{array}$ & 1 & $\begin{array}{c}\text { silt } \\
(0.009 \\
\mathrm{mm})\end{array}$ & $\begin{array}{c}\text { sub- } \\
\text { rounded - } \\
\text { sub-angular }\end{array}$ & & $\begin{array}{l}\text { thin-walled } \\
\text { brachiopod } \\
(2)\end{array}$ & & $20 \mathrm{x}$ & reflected & siliceous tarl \\
\hline $\begin{array}{c}\text { A-7705 } \\
\text { (F) }\end{array}$ & 2 & $\begin{array}{c}\text { silt } \\
(0.009 \\
\mathrm{mm})\end{array}$ & $\begin{array}{c}\text { sub- } \\
\text { rounded - } \\
\text { sub-angular }\end{array}$ & & $\begin{array}{c}\text { fragmented } \\
\text { radiolarians } \\
(2) \\
\end{array}$ & $\begin{array}{c}\text { some } \\
\text { framboids }\end{array}$ & $20 \mathrm{x}$ & reflected & siliceous tarl \\
\hline $\begin{array}{c}\text { A-7730 } \\
\text { (G) }\end{array}$ & 1 & $\begin{array}{c}\text { silt } \\
(0.009 \\
\mathrm{mm})\end{array}$ & $\begin{array}{c}\text { sub- } \\
\text { rounded - } \\
\text { sub-angular }\end{array}$ & & $\begin{array}{c}\text { pyritized } \\
\text { radiolarian } \\
(2) \\
\end{array}$ & framboids & $20 x$ & reflected & siliceous tarl \\
\hline
\end{tabular}




\begin{tabular}{|c|c|c|c|c|c|c|c|c|c|}
\hline Sample & $\begin{array}{c}\text { Picture } \\
\#\end{array}$ & $\begin{array}{c}\text { Quartz } \\
\text { Grain } \\
\text { Size }\end{array}$ & $\begin{array}{l}\text { Quartz } \\
\text { Grain } \\
\text { Shape }\end{array}$ & $\begin{array}{c}\text { Sedimentary } \\
\text { Structures }\end{array}$ & Fossils & $\begin{array}{l}\text { Other } \\
\text { Details }\end{array}$ & Objective & Light Type & $\begin{array}{c}\text { Milliken } \\
\text { (2014) } \\
\text { Classification }\end{array}$ \\
\hline $\begin{array}{c}\text { A-7730 } \\
\text { (H) }\end{array}$ & 2 & $\begin{array}{c}\text { silt } \\
(0.009 \\
\mathrm{mm})\end{array}$ & $\begin{array}{c}\text { sub- } \\
\text { rounded - } \\
\text { sub-angular }\end{array}$ & & & $\begin{array}{c}\text { framboids } \\
\text { and organic } \\
\text { matter }\end{array}$ & $20 x$ & reflected & siliceous tarl \\
\hline $\begin{array}{c}\text { A-7760 } \\
\text { (I) }\end{array}$ & 1 & $\begin{array}{c}\text { silt } \\
(0.011 \\
\mathrm{mm})\end{array}$ & $\begin{array}{c}\text { sub- } \\
\text { rounded }\end{array}$ & no bedding & $\underset{\text { (2) }}{\text { radiolarian }}$ & framboids & $20 \mathrm{x}$ & reflected & $\begin{array}{l}\text { argillaceous } \\
\text { sarl }\end{array}$ \\
\hline $\begin{array}{c}\text { A-7760 } \\
\text { (J) }\end{array}$ & 2 & $\begin{array}{c}\text { silt } \\
(0.011 \\
\mathrm{mm})\end{array}$ & $\begin{array}{l}\text { sub- } \\
\text { rounded }\end{array}$ & no bedding & & framboids & $20 \mathrm{x}$ & transmitted & $\begin{array}{l}\text { argillaceous } \\
\text { sarl }\end{array}$ \\
\hline $\begin{array}{c}\mathrm{C}-7032 \\
\text { (K) }\end{array}$ & 1 & $\begin{array}{c}\text { silt } \\
(0.015 \\
\mathrm{mm})\end{array}$ & sub-angular & laminations & & $\begin{array}{l}\text { little pyrite, } \\
\text { zircon } \\
\text { crystal }\end{array}$ & $20 \mathrm{x}$ & reflected & siliceous tarl \\
\hline $\begin{array}{c}\text { C-7032 } \\
\text { (L) }\end{array}$ & 2 & $\begin{array}{c}\text { silt } \\
(0.015 \\
\mathrm{mm})\end{array}$ & sub-angular & laminations & & & $20 \mathrm{x}$ & reflected & siliceous tarl \\
\hline $\begin{array}{c}\text { C-7060 } \\
\text { (M) }\end{array}$ & 1 & $\begin{array}{c}\text { silt } \\
(0.014 \\
\mathrm{mm})\end{array}$ & sub-angular & $\begin{array}{c}\text { few faint } \\
\text { laminations }\end{array}$ & $\begin{array}{l}\text { foraminifera } \\
\text { wall } \\
\text { fragment }\end{array}$ & $\begin{array}{c}\text { calcite } \\
\text { filled veins }\end{array}$ & $20 \mathrm{x}$ & reflected & calcareous tarl \\
\hline $\begin{array}{c}\text { C-7060 } \\
(\mathrm{N})\end{array}$ & 2 & $\begin{array}{l}\text { silt } \\
(0.014 \\
\mathrm{mm})\end{array}$ & sub-angular & $\begin{array}{c}\text { few faint } \\
\text { laminations }\end{array}$ & $\begin{array}{c}\text { euhedral } \\
\text { pyrite in } \\
\text { foraminifera } \\
(1)\end{array}$ & $\begin{array}{c}\text { calcite } \\
\text { filled veins }\end{array}$ & $20 \mathrm{x}$ & transmitted & calcareous tarl \\
\hline $\begin{array}{c}\mathrm{C}-7075 \\
(\mathrm{O})\end{array}$ & 1 & $\begin{array}{c}\text { silt } \\
(0.015 \\
\mathrm{mm})\end{array}$ & sub-angular & $\begin{array}{l}\text { few faint } \\
\text { laminations }\end{array}$ & & & $20 \mathrm{x}$ & reflected & $\begin{array}{l}\text { argillaceous } \\
\text { sarl }\end{array}$ \\
\hline $\begin{array}{c}\text { C-7075 } \\
\text { (P) }\end{array}$ & 2 & $\begin{array}{c}\text { silt } \\
(0.015 \\
\mathrm{mm})\end{array}$ & sub-angular & $\begin{array}{c}\text { few faint } \\
\text { laminations }\end{array}$ & & $\begin{array}{l}\text { euhedral } \\
\text { pyrite }\end{array}$ & $20 \mathrm{x}$ & reflected & $\begin{array}{l}\text { argillaceous } \\
\text { sarl }\end{array}$ \\
\hline
\end{tabular}




\begin{tabular}{|c|c|c|c|c|c|c|c|c|c|}
\hline Sample & $\begin{array}{c}\text { Picture } \\
\#\end{array}$ & $\begin{array}{c}\text { Quartz } \\
\text { Grain } \\
\text { Size }\end{array}$ & $\begin{array}{l}\text { Quartz } \\
\text { Grain } \\
\text { Shape }\end{array}$ & $\begin{array}{c}\text { Sedimentary } \\
\text { Structures }\end{array}$ & Fossils & $\begin{array}{l}\text { Other } \\
\text { Details }\end{array}$ & Objective & Light Type & $\begin{array}{c}\text { Milliken } \\
\text { (2014) } \\
\text { Classification }\end{array}$ \\
\hline $\begin{array}{c}C-7110 \\
(Q)\end{array}$ & 1 & $\begin{array}{c}\text { silt } \\
(0.011 \\
\mathrm{mm})\end{array}$ & $\begin{array}{c}\text { sub- } \\
\text { rounded }\end{array}$ & $\begin{array}{l}\text { very few } \\
\text { laminations }\end{array}$ & & $\begin{array}{l}\text { calcite } \\
\text { filled veins }\end{array}$ & $20 \mathrm{x}$ & reflected & $\begin{array}{l}\text { argillaceous } \\
\text { sarl }\end{array}$ \\
\hline $\begin{array}{c}\text { C-7110 } \\
\text { (R) }\end{array}$ & 2 & $\begin{array}{c}\text { silt } \\
(0.011 \\
\mathrm{mm})\end{array}$ & $\begin{array}{c}\text { sub- } \\
\text { rounded }\end{array}$ & $\begin{array}{l}\text { very few } \\
\text { laminations }\end{array}$ & & $\begin{array}{c}\text { calcite } \\
\text { filled veins }\end{array}$ & $20 x$ & transmitted & $\begin{array}{l}\text { argillaceous } \\
\text { sarl }\end{array}$ \\
\hline $\begin{array}{c}\text { C-7144 } \\
\text { (S) }\end{array}$ & 1 & $\begin{array}{c}\text { silt } \\
(0.011 \\
\mathrm{mm})\end{array}$ & $\begin{array}{c}\text { sub- } \\
\text { rounded - } \\
\text { sub-angular }\end{array}$ & $\begin{array}{l}\text { few faint } \\
\text { laminations }\end{array}$ & & $\begin{array}{c}\text { calcite } \\
\text { filled veins }\end{array}$ & $20 \mathrm{x}$ & reflected & $\begin{array}{l}\text { argillaceous } \\
\text { sarl }\end{array}$ \\
\hline $\begin{array}{c}\mathrm{C}-7144 \\
(\mathrm{~T})\end{array}$ & 2 & $\begin{array}{c}\text { silt } \\
(0.011 \\
\mathrm{mm})\end{array}$ & $\begin{array}{c}\text { sub- } \\
\text { rounded - } \\
\text { sub-angular }\end{array}$ & & & $\begin{array}{l}\text { calcite } \\
\text { filled veins }\end{array}$ & $20 \mathrm{x}$ & transmitted & $\begin{array}{l}\text { argillaceous } \\
\text { sarl }\end{array}$ \\
\hline
\end{tabular}

(1) Identified using Horowitz and Potter (1971) and Chen (2016).

(2) Identified using Horowitz and Potter (1971) and Hupp (2017). 


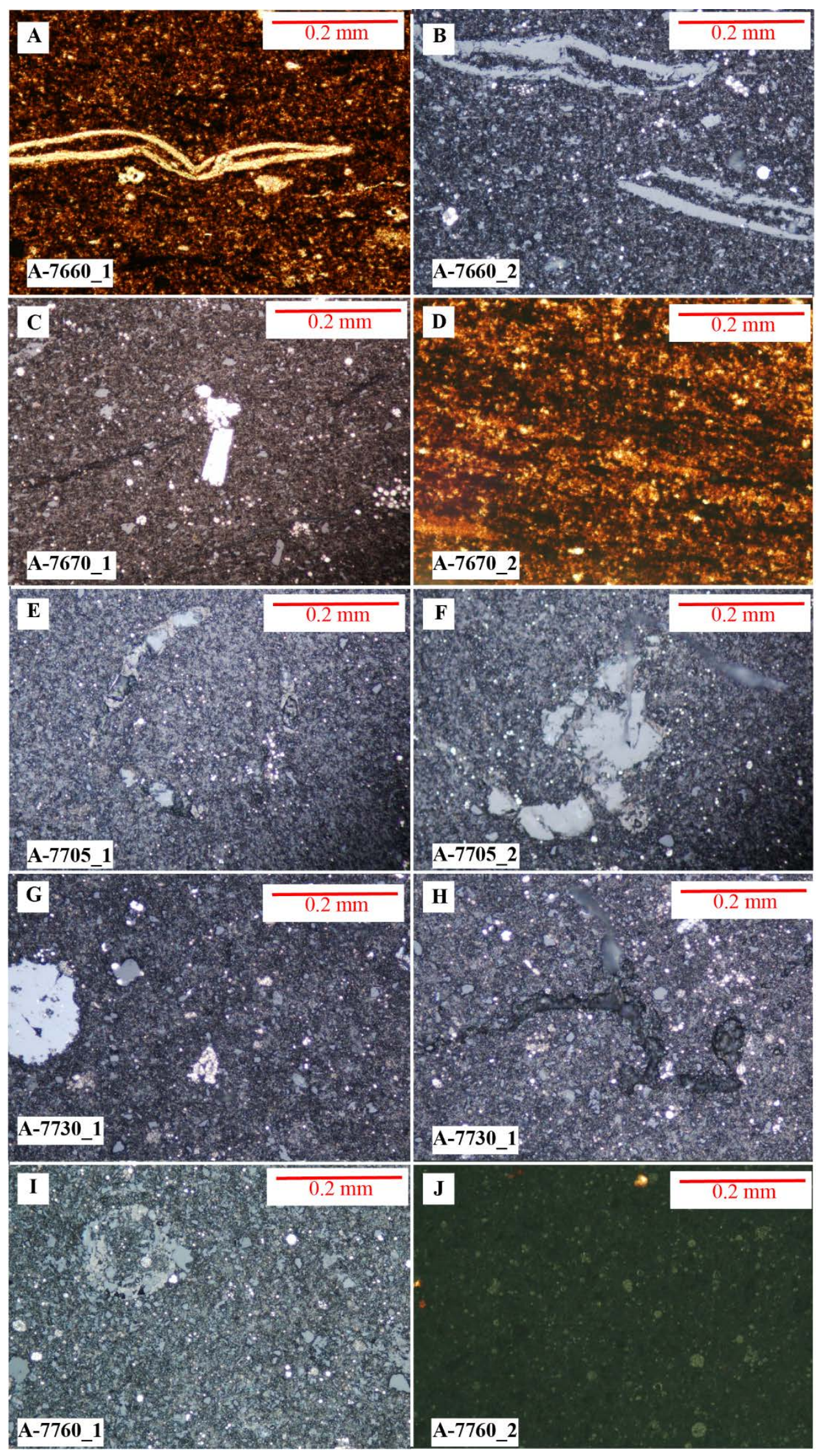



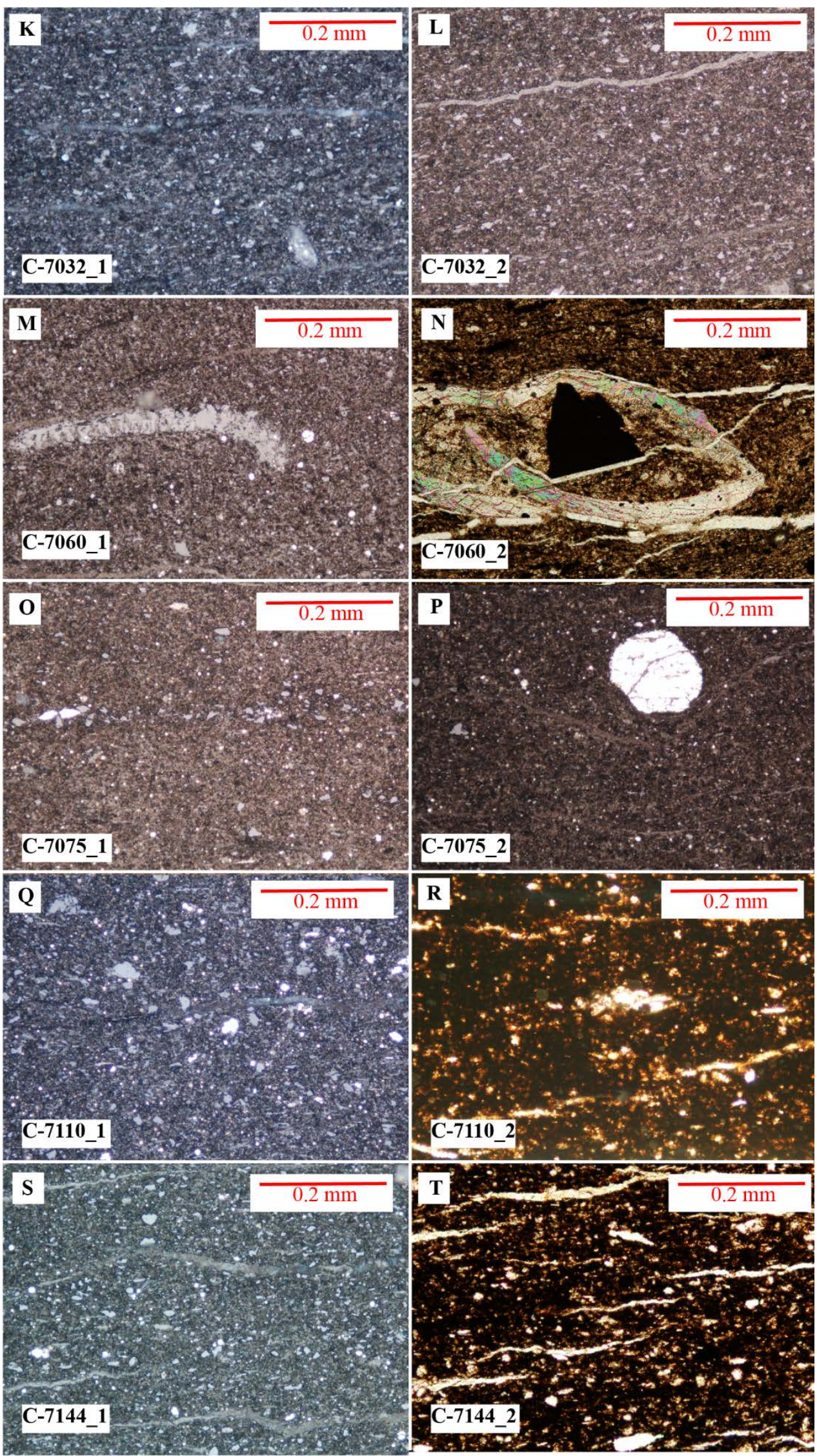
APPENDIX III. XRD mineralogy results from the Armstrong \#1 well collected by Core Laboratories.

\begin{tabular}{|c|c|c|c|c|c|c|c|}
\hline Depth & Calcite & Dolomite & Carbonate & Quartz & Total Clay & Chlorite & TOC \\
\hline $\mathbf{7 6 5 5}$ & 0.0 & 0.8 & 0.8 & 40.1 & 45.8 & 12.4 & 4.5 \\
\hline $\mathbf{7 6 7 5}$ & 75.0 & 16.0 & 91.0 & 3.9 & 4.4 & 1.3 & 1.4 \\
\hline $\mathbf{7 6 8 5}$ & 2.0 & 6.5 & 8.5 & 44.7 & 36.7 & 8.4 & 6.4 \\
\hline $\mathbf{7 6 9 5}$ & 3.3 & 2.8 & 6.1 & 34.0 & 43.3 & 6.8 & 4.1 \\
\hline $\mathbf{7 7 1 4}$ & 5.7 & 2.1 & 7.8 & 33.7 & 38.1 & 0.0 & 4.3 \\
\hline $\mathbf{7 7 3 4}$ & 1.9 & 1.7 & 3.6 & 58.5 & 26.4 & 0.0 & 5.8 \\
\hline $\mathbf{7 7 4 5}$ & 11.7 & 2.7 & 14.4 & 47.1 & 25.1 & 0.0 & 5.3 \\
\hline $\mathbf{7 7 5 2}$ & 20.9 & 1.1 & 22.0 & 46.7 & 19.9 & 0.0 & 4.6 \\
\hline $\mathbf{7 7 6 5}$ & 3.6 & 1.8 & 5.4 & 61.3 & 19.1 & 0.0 & 5.1 \\
\hline $\mathbf{7 7 7 4}$ & 93.5 & 0.6 & 94.1 & 5.5 & 0.0 & 0.0 & 2.4 \\
\hline
\end{tabular}


APPENDIX IV. XRD mineralogy results from the CSA well collected by Wonnell (2015).

\begin{tabular}{|c|c|c|c|c|c|c|c|}
\hline Depth & Calcite & Dolomite & Carbonate & Quartz & $\begin{array}{c}\text { Total } \\
\text { Clay }\end{array}$ & Chlorite & TOC \\
\hline $\mathbf{7 0 2 8 . 0}$ & 1.0 & 1.0 & 2.0 & 37.7 & 50.6 & 16.3 & 2.2 \\
\hline $\mathbf{7 0 3 8 . 0}$ & 0.0 & 0.4 & 0.4 & 37.3 & 52.1 & 15.8 & 4.1 \\
\hline $\mathbf{7 0 4 9 . 0}$ & 16.2 & 5.0 & 21.2 & 30.1 & 40.2 & 14.1 & 5.0 \\
\hline $\mathbf{7 0 5 8 . 6}$ & & & 5.0 & 52.0 & 39.0 & & 2.0 \\
\hline $\mathbf{7 0 5 9 . 0}$ & 0.0 & 0.0 & 0.0 & 31.8 & 56.9 & 13.9 & \\
\hline $\mathbf{7 0 6 4 . 6}$ & & & 5.0 & 51.0 & 41.0 & & 6.5 \\
\hline $\mathbf{7 0 6 9 . 3}$ & & & 32.0 & 36.0 & 29.0 & & \\
\hline $\mathbf{7 0 7 0 . 0}$ & 33.1 & 3.7 & 36.8 & 25.0 & 30.1 & 8.8 & \\
\hline $\mathbf{7 0 7 4 . 5}$ & & & 1.0 & 45.0 & 48.0 & & 5.0 \\
\hline $\mathbf{7 0 7 8 . 2}$ & & & 13.0 & 42.0 & 37.0 & & \\
\hline $\mathbf{7 0 7 9 . 0}$ & 5.1 & 1.7 & 6.8 & 26.6 & 40.3 & 10.6 & \\
\hline $\mathbf{7 0 8 2 . 4}$ & & & 0.0 & 48.0 & 42.0 & & \\
\hline $\mathbf{7 0 8 9 . 0}$ & 0.3 & 0.0 & 0.3 & 44.4 & 41.9 & 9.9 & 6.5 \\
\hline $\mathbf{7 0 9 5 . 5}$ & & & 5.0 & 48.0 & 41.0 & & 4.0 \\
\hline $\mathbf{7 0 9 8 . 0}$ & & & 5.0 & 51.0 & 38.0 & & \\
\hline $\mathbf{7 0 9 9 . 5}$ & 0.6 & 0.4 & 1.0 & 33.1 & 47.8 & 8.9 & \\
\hline $\mathbf{7 1 0 2 . 1}$ & & & 3.0 & 49.0 & 39.0 & & \\
\hline $\mathbf{7 1 0 7 . 0}$ & 13.2 & 3.7 & 16.9 & 35.6 & 38.6 & 8.8 & 5.0 \\
\hline $\mathbf{7 1 0 8 . 4}$ & & & 9.0 & 50.0 & 35.0 & & \\
\hline $\mathbf{7 1 1 4 . 5}$ & & & 5.0 & 34.0 & 56.0 & & 4.5 \\
\hline $\mathbf{7 1 1 9 . 0}$ & 10.4 & 3.0 & 13.4 & 35.3 & 38.8 & 7.4 & \\
\hline $\mathbf{7 1 2 4 . 8}$ & & & 2.0 & 50.0 & 42.0 & & 3.5 \\
\hline $\mathbf{7 1 2 5 . 9}$ & & & 3.0 & 52.0 & 39.0 & & \\
\hline $\mathbf{7 1 2 7 . 0}$ & & & 30.0 & 39.0 & 26.0 & & \\
\hline $\mathbf{7 1 2 8 . 0}$ & 12.3 & 1.6 & 13.9 & 33.8 & 34.8 & 7.3 & \\
\hline $\mathbf{7 1 3 0 . 0}$ & & & 5.0 & 5.2 & 38.0 & & \\
\hline $\mathbf{7 1 3 3 . 8}$ & & & 4.0 & 51.0 & 40.0 & & 6.0 \\
\hline $\mathbf{7 1 3 4 . 9}$ & & & 3.0 & 54.0 & 38.0 & & \\
\hline $\mathbf{7 1 3 5 . 0}$ & 7.5 & 1.4 & 8.9 & 39.8 & 38.3 & 6.7 & \\
\hline $\mathbf{7 1 3 6 . 9}$ & & & 13.0 & 47.0 & 35.0 & & \\
\hline $\mathbf{7 1 4 0 . 0}$ & & & 9.0 & 49.0 & 35.0 & & \\
\hline $\mathbf{7 1 4 5 . 0}$ & 2.6 & 1.0 & 3.6 & 38.4 & 43.1 & 8.1 & 8.0 \\
\hline $\mathbf{7 1 4 5 . 8}$ & & & 2.0 & 49.5 & 39.6 & & \\
\hline $\mathbf{7 1 4 8 . 7}$ & & & 5.0 & 50.0 & 39.0 & & \\
\hline $\mathbf{7 1 5 0 . 1}$ & & & 5.0 & 43.0 & 40.0 & & \\
\hline $\mathbf{7 1 5 4 . 4}$ & & & 6.0 & 47.0 & 35.0 & & \\
\hline $\mathbf{7 1 5 4 . 8}$ & & & 5.0 & 42.4 & 36.4 & & \\
\hline $\mathbf{7 1 5 5 . 0}$ & 11.3 & 3.2 & 14.5 & 60.3 & 13.5 & 1.0 & \\
\hline & & & & & & & \\
\hline
\end{tabular}


APPENDIX V. Raw data of the Sm-Nd isotopic analysis. “A” represents the Armstrong \#1 well. "C” represents the Coldstream well.

\begin{tabular}{|c|c|c|c|c|c|c|c|c|c|c|}
\hline $\begin{array}{c}\text { Sample } \\
\text { Name }\end{array}$ & A-7660 & A-7670 & A-7705 & A-7730 & A-7760 & C-7032 & C-7060 & C-7075 & C-7110 & C-7144 \\
\hline Sample (g) & 0.02682 & 0.02942 & 0.02641 & 0.02770 & 0.02822 & 0.02679 & 0.02309 & 0.02639 & 0.02241 & 0.02397 \\
\hline Spike (g) & 0.21891 & 0.24239 & 0.21637 & 0.22640 & 0.21639 & 0.21950 & 0.19008 & 0.21652 & 0.18422 & 0.19719 \\
\hline \multicolumn{11}{|l|}{ Raw Data } \\
\hline${ }^{143} \mathbf{N d} /{ }^{144} \mathbf{N d}$ & 0.512069 & 0.512077 & 0.512088 & 0.512147 & 0.512158 & 0.512062 & 0.512090 & 0.512046 & 0.512084 & 0.512074 \\
\hline $\begin{array}{r}1 \sigma \% \text { Std. } \\
\text { Error }\end{array}$ & 0.000900 & 0.000800 & 0.000900 & 0.000900 & 0.000800 & 0.000900 & 0.000800 & 0.000800 & 0.000800 & 0.001800 \\
\hline${ }^{147} \mathrm{Sm} /{ }^{152} \mathrm{Sm}$ & 1.260868 & 1.219011 & 1.091014 & 1.063994 & 0.868336 & 1.128917 & 1.073056 & 1.268579 & 1.264566 & 1.118199 \\
\hline $\begin{array}{l}\text { 1s \% Std. } \\
\text { Error }\end{array}$ & 0.002300 & 0.002000 & 0.001200 & 0.001700 & 0.002000 & 0.002200 & 0.001800 & 0.001500 & 0.002000 & 0.002400 \\
\hline $\begin{array}{r}{ }^{149} \mathrm{Sm} / \\
{ }^{152} \mathrm{Sm}_{\text {(raw) }}\end{array}$ & 0.522127 & 0.522490 & 0.522544 & 0.522105 & 0.521288 & 0.522819 & 0.521511 & 0.522222 & 0.522892 & 0.522363 \\
\hline \multicolumn{11}{|l|}{ Calculated } \\
\hline Nd ppm & 28.2 & 30.1 & 34.3 & 33.5 & 53.9 & 31.6 & 35.1 & 28.9 & 27.5 & 33.7 \\
\hline Sm ppm & 5.3 & 5.7 & 7 & 7.4 & 11.4 & 6.6 & 7.3 & 5.3 & 5.3 & 6.7 \\
\hline${ }^{147} \mathrm{Sm} /{ }^{144} \mathrm{Nd}$ & 0.1139 & 0.1144 & 0.1242 & 0.1339 & 0.1280 & 0.1259 & 0.1263 & 0.1103 & 0.1169 & 0.1207 \\
\hline $2 \sigma$ & 0.0008 & 0.0008 & 0.0009 & 0.0009 & 0.0008 & 0.0008 & 0.0009 & 0.0008 & 0.0008 & 0.0008 \\
\hline $\mathbf{T}_{\mathrm{DM}} \mathbf{G a}$ & $1.65 \mathrm{E}+09$ & $1.64 \mathrm{E}+09$ & $1.80 \mathrm{E}+09$ & $1.91 \mathrm{E}+09$ & $1.76 \mathrm{E}+09$ & $1.88 \mathrm{E}+09$ & $1.84 \mathrm{E}+09$ & $1.62 \mathrm{E}+09$ & $1.68 \mathrm{E}+09$ & $1.76 \mathrm{E}+09$ \\
\hline$\varepsilon_{\text {Nd }}$ & -11.10 & -10.94 & -10.73 & -9.58 & -9.36 & -11.25 & -10.69 & -11.55 & -10.81 & -11.00 \\
\hline $2 \sigma$ & 0.18 & 0.16 & 0.18 & 0.18 & 0.16 & 0.18 & 0.16 & 0.16 & 0.16 & 0.36 \\
\hline
\end{tabular}


APPENDIX VI. Ten Raman spectra for each depth in the CSA, Armstrong \#1, and MSEEL wells. Raman shift $\left(\mathrm{cm}^{-1}\right)$ is on the $\mathrm{x}$-axis and counts is on the $\mathrm{y}$-axis. All spectra have peaks around 1350 and $1600 \mathrm{~cm}^{-1}$.

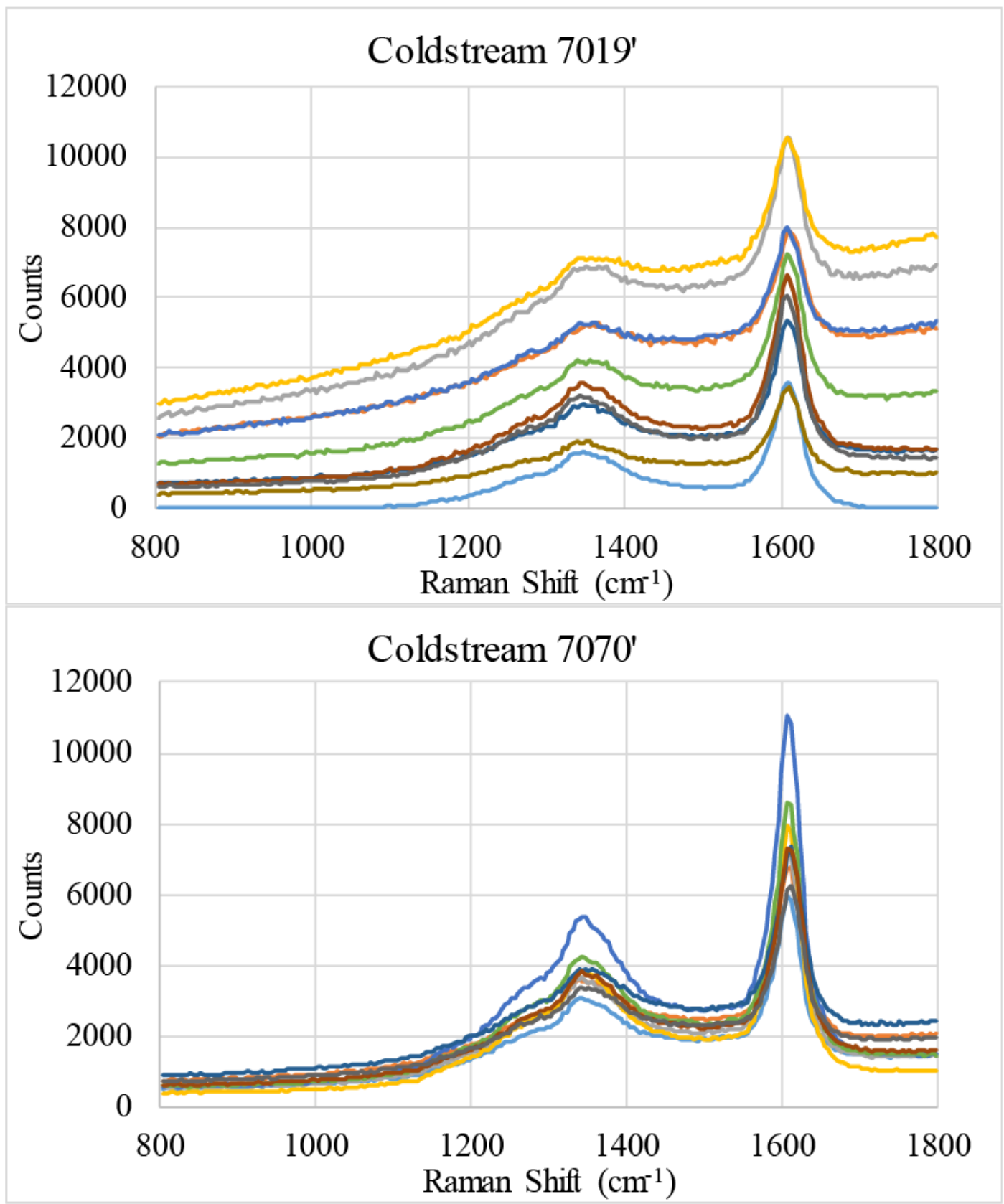




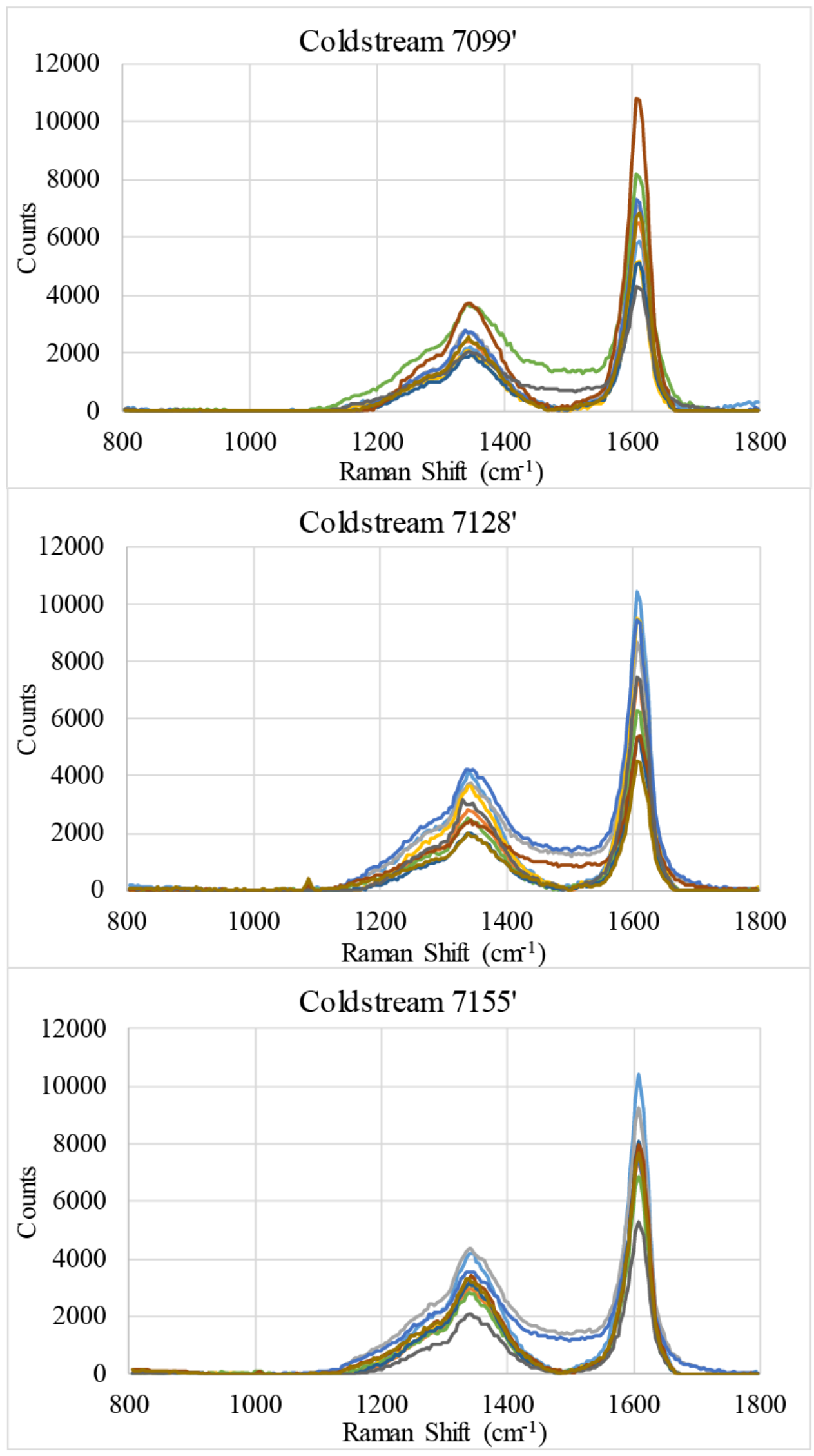




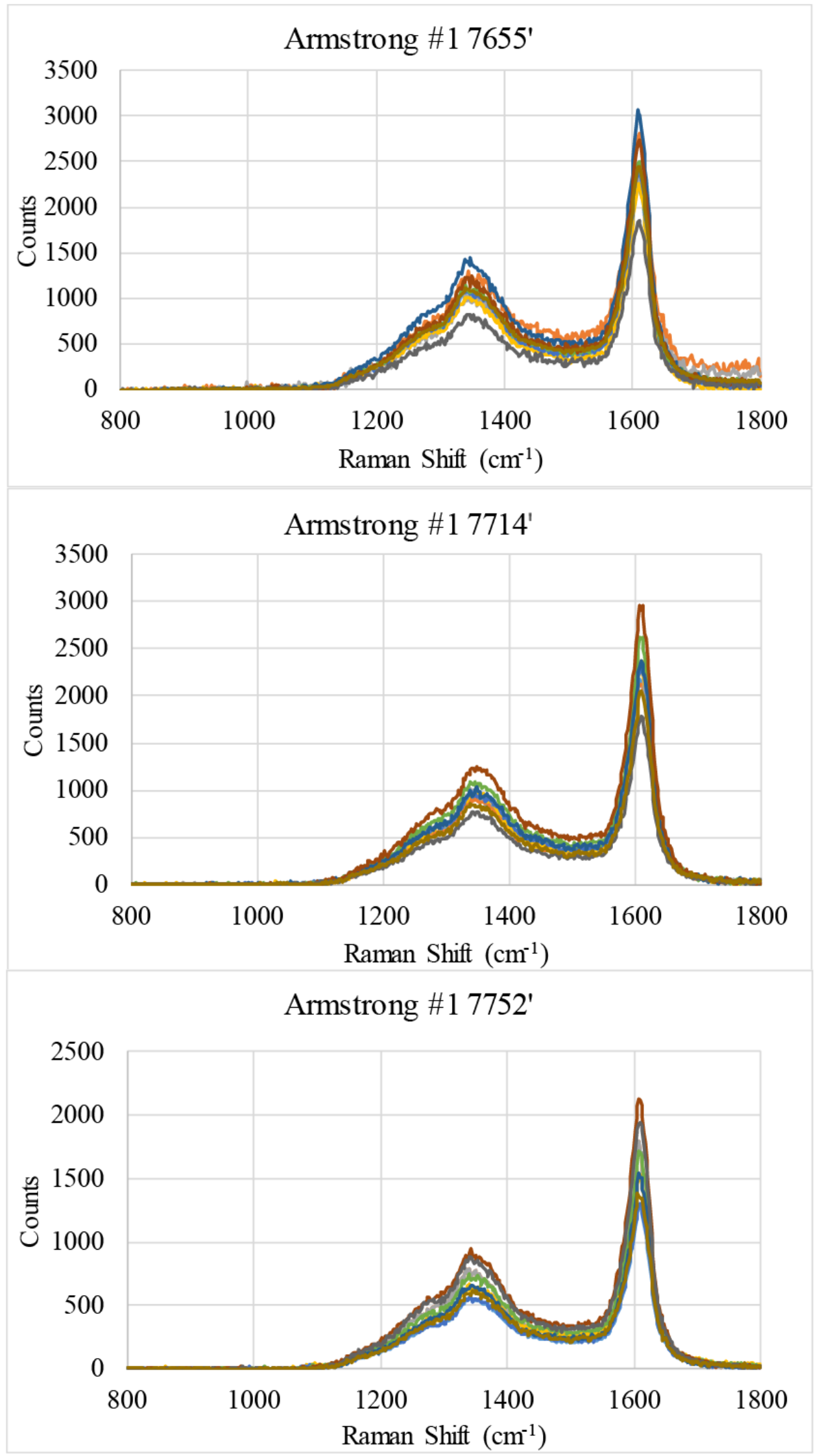




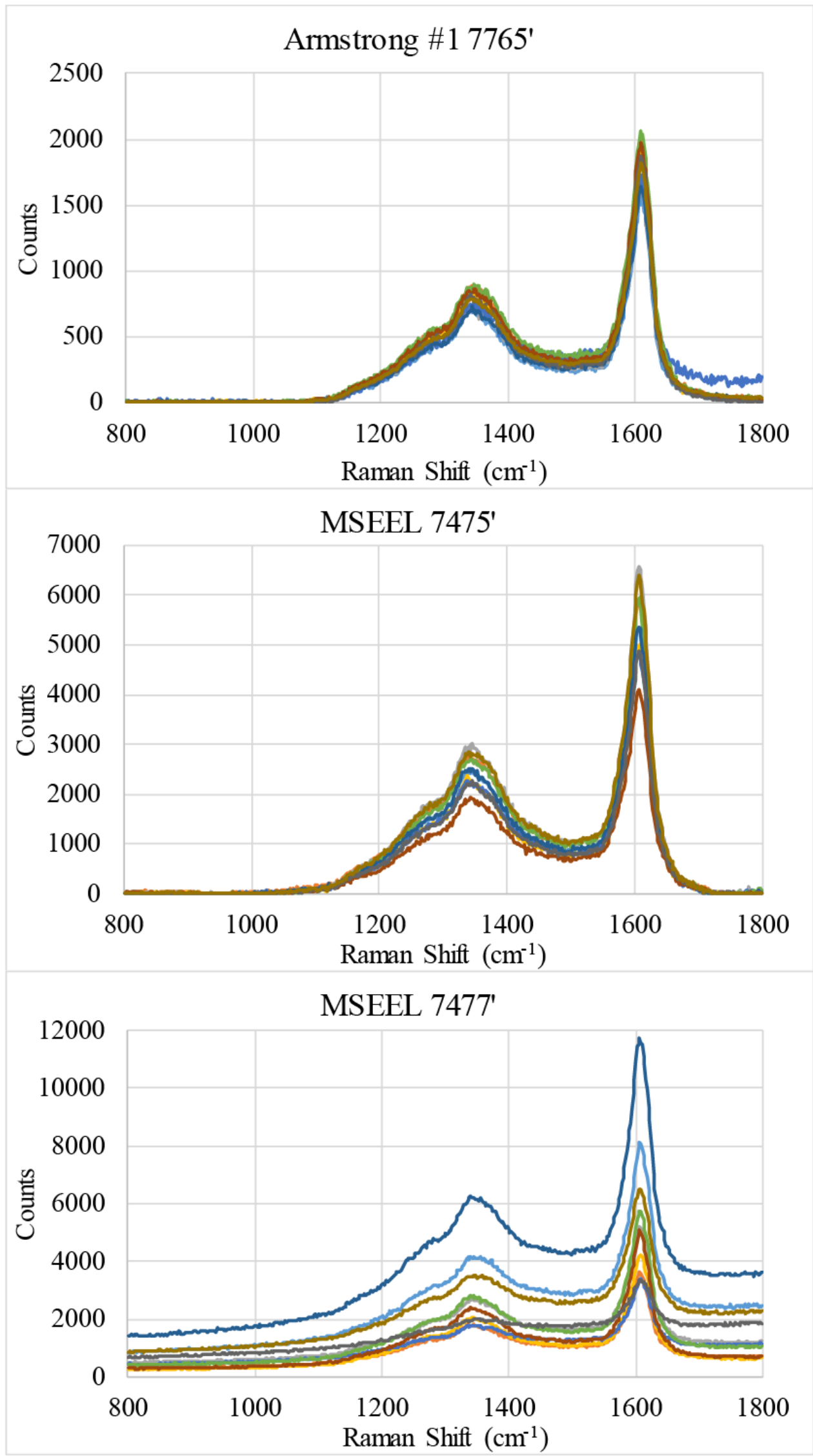




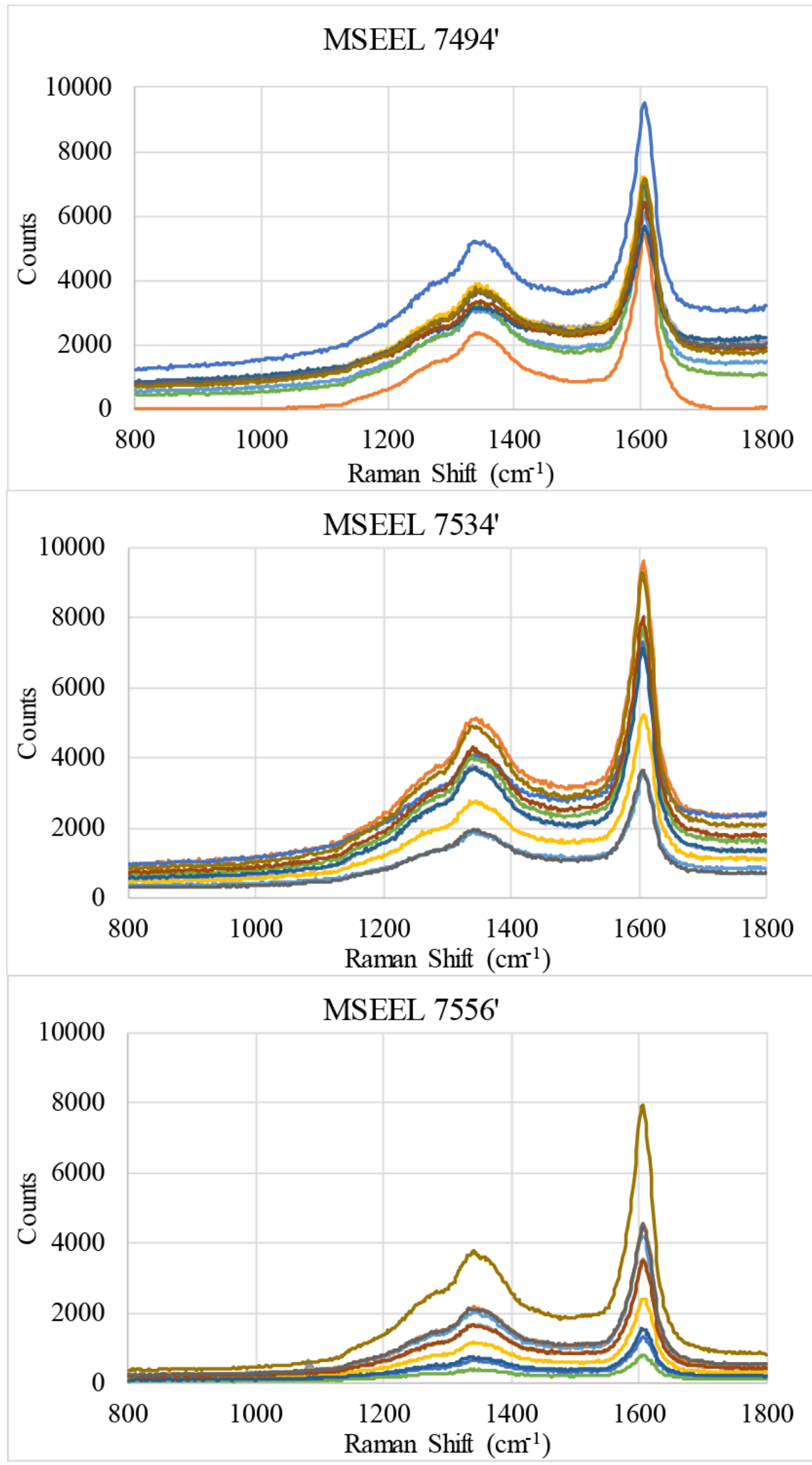


APPENDIX VII. Six-peak fit on a spectrum from the CSA well at a depth of 7099 feet.

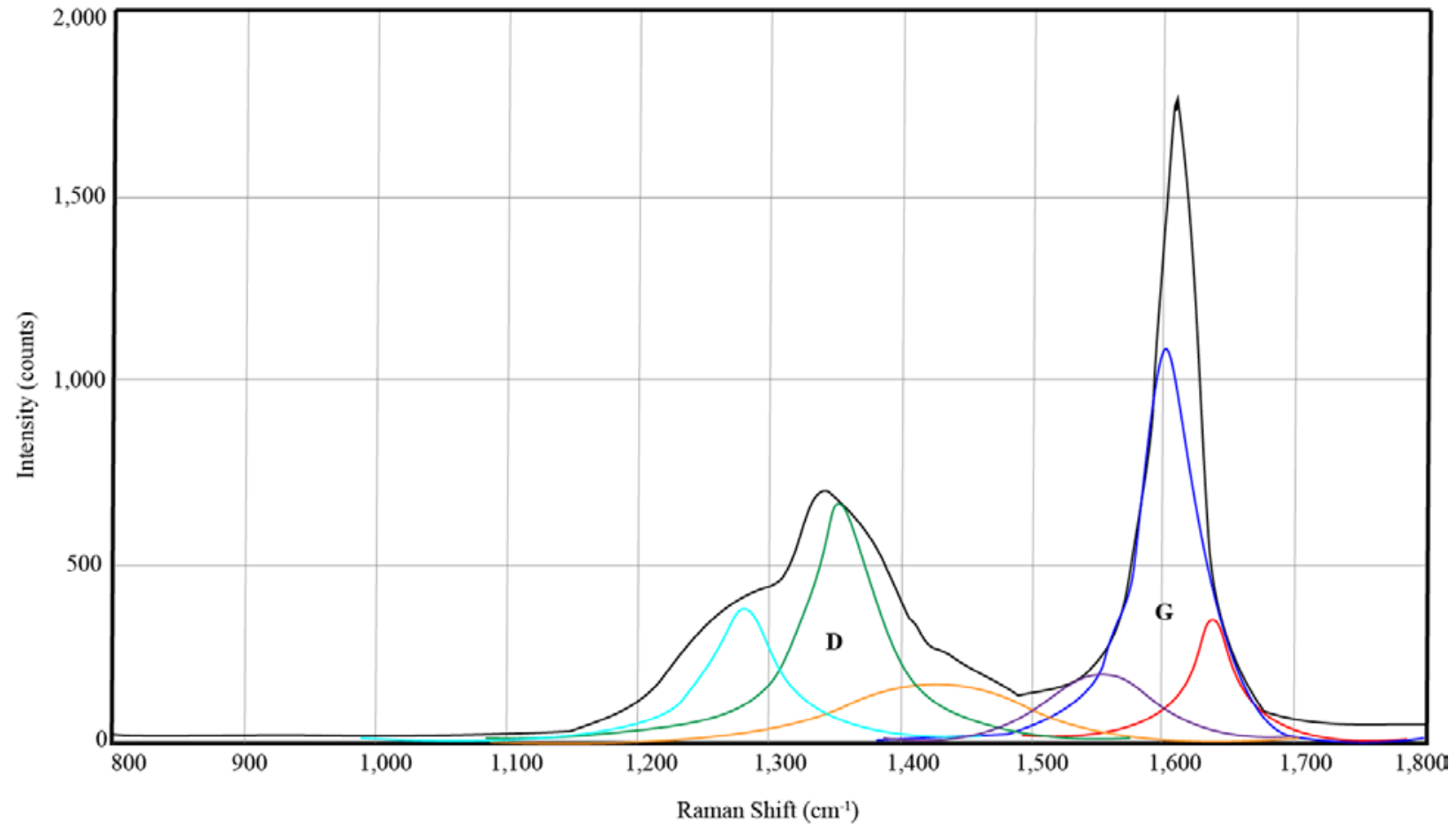


APPENDIX VIII. REE concentrations of the Armstrong \#1 and CSA wells normalized to chondrite. $\boldsymbol{\tau}_{\mathrm{DM}}$ is displayed next to the depth as a comparison of REE enrichment during older $\tau_{\text {DM }}$ ages.
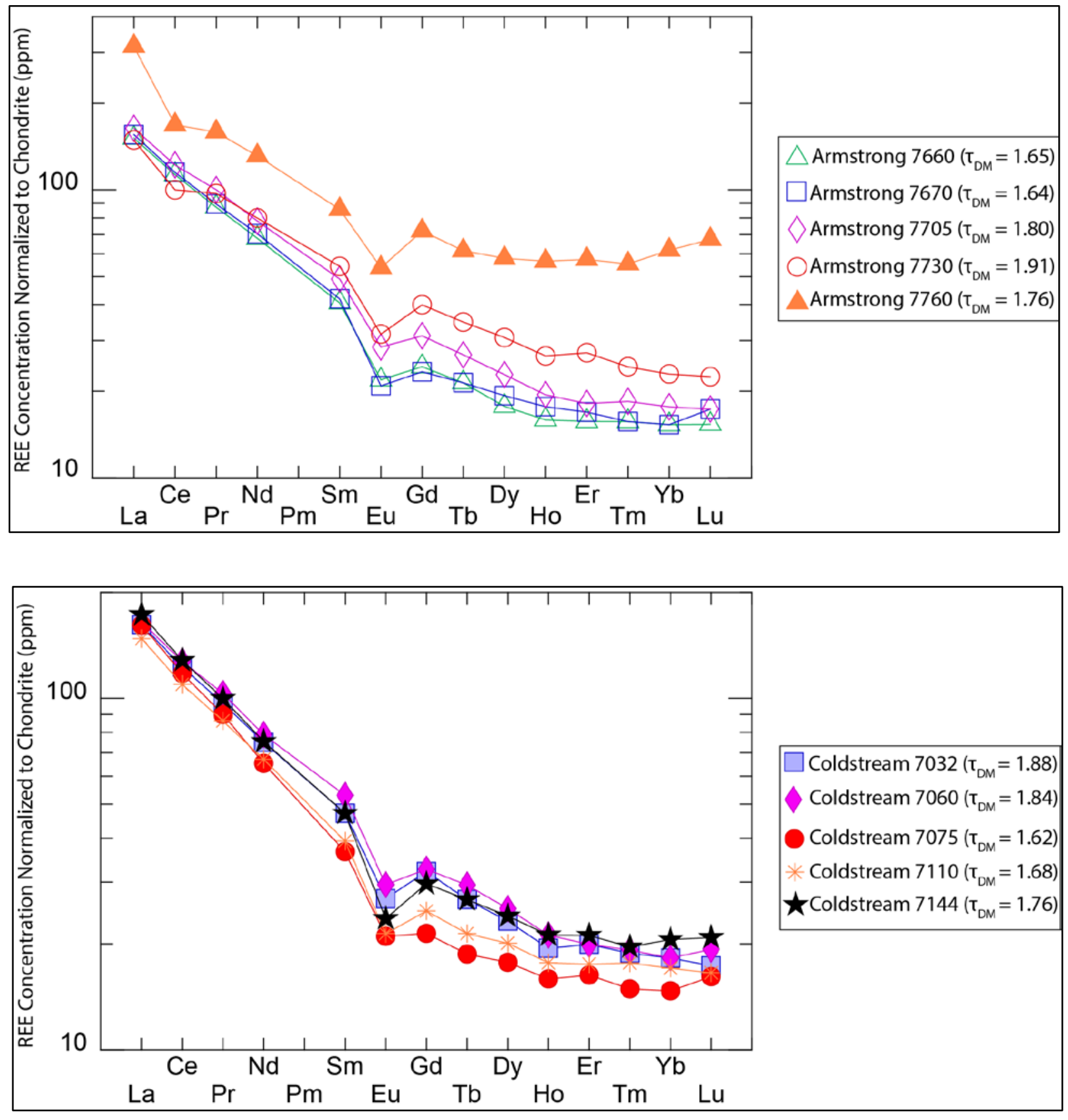